\title{
Advising Presidents: Robert Jackson and the Destroyers-For-Bases Deal
}

\author{
by William R. CASTo*
}

\begin{abstract}
In recent years, the process of providing legal advice at the highest levels of government has sparked significant controversies. The present article uses advice given to President Franklin Roosevelt by Attorney General Robert Jackson, later Justice Jackson, to explore this advisory process. There is no comparable, in-depth study of the relationship between any president and the president's legal advisors.

The United States was a neutral country in the summer of 1940, and Great Britain stood alone against a triumphant Nazi Germany. President Roosevelt transferred fifty American destroyers to the British in their hour of need, and the president relied in part upon Jackson's formal written advice that the transfer would be lawful. This episode, which involved a respected president and a respected attorney general, provides an invaluable laboratory for exploring the advisory process. Discussions of legal advice given to presidents over the last decade are inevitably distorted by rancorous partisanship. In contrast, Attorney General Jackson's advice is distant in time and relatively uncontroversial. Today, everyone agrees that the substantive policy of supporting Great Britain against Nazi Germany was the right policy. Based upon an in-depth study of Jackson's conduct, the present article concludes that the tra-
\end{abstract}

* Paul Whitfield Horn Professor, Texas Tech University. I wish to thank Professors John Q. Barret, Bryan Camp, Susan Fortney, Scott Gerber, Adam Morse, Richard Murphy and $\mathrm{H}$. Jefferson Powell for their thoughtful comments and assistance regarding the present article. I also wish to thank the participants in faculty colloquia at the Texas Tech University School of Law and the St. Mary's University at San Antonio School of Law. 
ditional principles of professional responsibility provide an inadequate basis for understanding the relationship between a president and his legal advisers.

The Summer of 1940 was a dark season for Western Civilization. In May and June, German armies rampaged through the Low Countries and smashed France's surprisingly ineffective defenses to pieces. Then Italy entered the war. Great Britain now stood alone against "Hitler's gospel of hatred, appetite, and domination." ${ }^{1}$ Invasion seemed imminent, and only the Channel patrolled by the Royal Navy stood between Britain and the triumphant Wehrmacht. In August, these dire straits occasioned Attorney General Robert Jackson's Destroyers-For-Bases opinion, which is one of the most famous non-judicial legal opinions in American history. ${ }^{2}$ A decade later, Jackson believed that "the turning point in the relations of this country to the war came with the destroyer transaction." ${ }^{3}$

Destroyers were crucial to the defense of the narrow and comparatively shallow seas around Britain, and destroyers were in short supply. In Winston Churchill's' first cable to President Franklin Roosevelt after becoming Prime Minister, he urgently outlined Britain's "immediate needs [as] first of all, the loan of 40 or 50 of your older destroyers." ${ }^{4}$ Churchill bluntly explained that without more destroy-

\footnotetext{
${ }^{1}$ Winston Churchill, BBC Broadcast, 14 July 1940, The Churchill War Papers, ed. Martin Gilbert (New York: W. W. Norton \& Company, 1995), 2:517.

239 Op. Atty Gen. 484 (1940). In terms of the legal issues actually covered, two early opinions by Alexander Hamilton are more important. Alexander Hamilton, "Opinion on the Constitutionality of an Act to Establish a Bank" (1791), Papers of Alexander Hamilton, ed. Harold C. Syrett and Jacob E. Cooke (New York: Columbia Univ. Press, 1964), 8:97 (scope of necessary-and-proper clause); Alexander Hamilton, "Pacificus No. 1" (President's executive powers) discussed in William Casto, Foreign Affairs and the Constitution in the Age of Fighting Sail (Columbia, SC: Univ. of South Carolina Press, 2006), ch. 5 \& 10. See also, generally The Federalist, ed. Jacob E. Cooke (Middleton, CT: Wesleyan University Press, 1961. The torture memoranda of recent years have achieved a notoriety approaching the fame of Jackson's opinion.

${ }^{3}$ Robert H. Jackson to Allan Nevins, 30 October 1952, Robert Jackson Papers, Library of Congress, Washington, DC. Secretary of War Stimson agreed. Diaries of Henry L. Stimson, 17 August 1940, Henry L. Stimson Papers, Yale University; Henry Stimson to Charles C. Burlingham, 25 August 1940, Charles Burlingham Papers, Harvard Law Library.

${ }^{4}$ Telegram of 15 May 1940, quoted and discussed in Martin Gilbert, Finest Hour: Winston S. Churchill, 1939-1941, (London: Heinemann, 1983), 6:345-46.
} 
ers, "we may be strained to breaking-point." ${ }^{5}$ In a "jigsaw puzzle"6 of politically and diplomatically intricate discussions beginning with the Prime Minister's request and reaching fruition in late August, President Roosevelt agreed to exchange fifty destroyers for base rights in the western Atlantic and the Caribbean. A sine qua non to the deal was Attorney General Jackson's opinion that the president had unilateral authority to effect the exchange. The general story of the Destroyers-for-Bases Deal has been well told elsewhere ${ }^{7}$ and

5 Id.

${ }^{6}$ Robert H. Jackson, "The Exchange of Destroyers for Atlantic Bases," in That Man: An Insider's Portrait of Franklin D. Roosevelt, ed. John Q. Barrett (Oxford: Oxford Univ. Press, 2003), 82. In 1952 \& 1953, Jackson wrote an article on the Destroyers-for-Bases Deal that was never published. Professor Barrett has reprinted Jackson's final draft in his wonderful book That Man. Jackson's unpublished article is an invaluable source for understanding the Deal, but it cannot be taken at face value. Like any remembrance of things past, it is afflicted with memory problems inherent in the human condition. See notes $169 \&$ 573-626 below and accompanying text.

The Jackson Papers in the Library of Congress contain a number of preliminary drafts of the final draft. Robert $\mathrm{H}$. Jackson Papers, Box 57, Library of Congress. This file has a "table of contents" that lists the drafts in the following numerical order:

1-16: (n.d.; after 22 September 1952)

1-19: (22 September 1952)

1-20: (10 October 1952)

1-21: (12 November 1952)

1-22: (28 November 1952)

1-23: (3 December 1952)

$1-23 b$ (handwritten copy of 1-23)

1-24: (n.d.)

The present article uses the above numbers to refer to the individual drafts.

${ }^{7}$ David Reynolds, The Creation of the Anglo-American Alliance, 1937-41: A Study in Competitve Co-operation (Chapel Hill: Univ. of North Carolina Press, 1982), ch. $4 \& 5$ is the best overall treatment of the Deal because Reynolds does a superb job of placing the affair in the overall context of Anglo-American relations. Another excellent treatment that is especially good in giving the reader the British perspective is James R. Leutze, Bargaining For Supremacy: Anglo-American Naval Collaboration, 1937-1941 (Chapel Hill: Univ. of North Carolina, 1977). Norman Moss, Nineteen Weeks: America, Britain and the Fateful Summer of 1940 (Boston: Houghton Mifflin, 2003) is a well researched and well written story of the summer of 1940 directed at a popular audience. Two valuable and more narrowly focused histories are Philip Goodhart, Fifty Ships That Saved The World: The Foundation of the Anglo-American Alliance (London: Heinemann, 1965) and Robert Shogan, Hard Bargain: How FDR Twisted Churchill's Arm, Evaded the Law, and Changed the Role 
need not be recounted in all its details. The present article concentrates on the process that produced Jackson's legal opinion.

The specific legal issues involved in the Destroyers-for-Bases Deal have virtually no direct relevance today, but the Deal provides an invaluable laboratory for beginning an exploration of the process of providing legal advice at the highest levels of government. Until recent times, comparatively little attention has been paid to the attorney-advisory process in government. ${ }^{8}$ The breathtaking expansiveness of some advisory opinions rendered during the administrations of George W. Bush has now sparked interest in the process. ${ }^{9}$ But contemporary discussions of these matters are distorted by tense and rancorous partisanship. In contrast, the Destroyers-forBases Deal is distant in time and relatively uncontroversial. These differences enable us to factor partisanship and substantive policy more-or-less out of our considerations. Today everyone agrees that the substantive policy of supporting Great Britain against Nazi Germany was the right policy. Finally, the Deal provides an invaluable laboratory because there is a quite detailed historical record that enables us to approach some semblance of an understanding of the advisory process that summer of 1940.

of the American Presidency (New York: Scribner, 1995). Shogan's Hard Bargain is thoroughly researched and extremely well grounded in original sources, but the author's analysis is flawed by unrealistic idealism in the realm of politics and a naive understanding of law. William Langer \& Everett Gleason, The Challenge of Isolation, 1937-1940 (Gloucester, MA: Peter Smith, 1952) is also valuable. The recent chapter length treatment in lan Kershaw, Fateful Choices: Ten Decisions That Changed the World, 1940-1941 (New York: Penguin, 2007), ch. 5 is good but largely derivative. The brief treatment in Llewellyn Woodward, British Foreign Policy in the Second World War (London: Her Majesty's Stationery Office, 1972), 84-92 is quite dry and relatively uninformative.

${ }^{8}$ Nancy V. Baker, Conflicting Loyalties: Law and Politics in the Attorney General's Office, 1789-1990 (Lawrence: Univ. Press of Kansas, 1992) is a noteworthy and valuable, early exception. For two recent and well-done analyses of the attorney advisory relationship in the Bush II administration, see Harold $\mathrm{H}$. Bruff, Bad Advice: Bush's Lawyers in the War on Terror (Lawrence, KS: University Press of Kansas, 2009); Norman Spaulding, "Independence and Experimentalism in the Department of Justice," Stanford Law Review 63 (2011):409. For a valuable lecture that superbly describes the very real problems confronting presidential advisors and that is more sympathetic to the Bush II attorney advisers, see Jack Goldsmith, "Reflections on Government Lawyering," Military Law Review 205 (2010) 192-203.

${ }^{9}$ See, e.g., Jay S. Bybee to Alberto Gonzales, memorandum, 1 August 2002, discussed in Bruff, Bad Advice, note 8 above; Spaulding, "Independence," note 8 above; Michael Hatfield, "Fear, Legal Indeterminacy and the American Lawyering Culture," Lewis \& Clark LawReview 10 (2006):511. 
Jackson's opinion was a sine qua non for the Deal, but the opinion was not solely his own. Much of the opinion originated in the brilliant and supple mind of Benjamin V. Cohen, who was the General Counsel of the National Power Policy Committee in the Interior Department. About a month before Jackson issued his opinion, Cohen wrote a memorandum offering a buffet of powerful and not so powerful legal analyses supporting the transfer of destroyers to the British. ${ }^{10}$ A few weeks later, Cohen refined his initial cut at the problem with the able assistance of Dean Acheson, an attorney in private practice. They published their analysis in the New York Times under Acheson's name. ${ }^{11}$ Within the Justice Department, Acting Assistant Solicitor General Newman A. Townsend was responsible for much of the ground work, ${ }^{12}$ and then there was Attorney General Jackson. The final opinion was Jackson's, and he took full responsibility for his controversial analyses and conclusions.

All four men who participated in this collaborative effort were solid, experienced, and respected attorneys, and some of them were extraordinarily gifted. Robert $H$. Jackson is almost universally admired as an enormously capable, trustworthy, and honorable attorney. He came to Washington in the early 1930s as a comparatively minor player in President Roosevelt's New Deal government, but as the decade proceeded, his abilities earned him progressively higher positions. In 1938, he became Solicitor General, and two years later Roosevelt appointed him Attorney General. ${ }^{13}$ Finally, the President named him to the Supreme Court in 1941. At the conclusion of the war, he took a leave of absence to serve as chief American prosecutor at the Nuremberg trials. He subsequently penned the most important judicial opinion ever written on the President's executive powers. ${ }^{14}$

\footnotetext{
${ }^{10}$ See notes 281-355 below and accompanying text.

${ }^{11}$ See notes 381-430 below and accompanying text.

${ }^{12}$ See notes 192-218 \& 446-55 below and accompanying text.

${ }^{13}$ For Jackson's service in the New Deal, see Eugene C. Gerhard, America's Advocate: Robert H. Jackson (Indianapolis: Bobbs-Merrill, 1958), ch. 5-13; Victoria A. Graffeo, "Robert H. Jackson: His Years as a Public Servant "Learned in the Law," Albany Law Review 68 (2005):539; Warner Gardner, "Government Attorney," Columbia Law Review, 55 (1955): 438.

${ }^{14}$ Youngstown Sheet \& Tube Co. v. Sawyer, 343 U.S. 579, 634 (1952) (concurring opinion).
} 
Benjamin Cohen began practicing law in the nation's capital in 1917 with the United States Shipping Board..$^{15}$ After the Great War, he spent most of his time on Wall Street, both as an attorney and as an investor. When Roosevelt became president, Cohen returned to Washington and quickly established himself as an important member of the new administration. In addition to arguing cases before the Supreme Court, he was a major participant in drafting some of the most important New Deal legislation and throughout the 1930 's, was a ubiquitous, albeit behind the scenes, player in the Roosevelt Administration's various activities. ${ }^{16}$ He participated in strategy sessions with the President and with Cabinet members, ${ }^{17}$ and he wrote countless speeches for them. In 1940, he was parked in the Department of Interior. Attorney General Jackson described Cohen "as having the best legal brains he has ever come in contact with." ${ }^{18}$ Cohen was a brilliant forty-six-year-old attorney with over twenty years of practice experience and a thorough understanding of the federal government's operations.

Dean Acheson epitomized the East-Coast Establishment. ${ }^{19}$ After Groton and Yale, he took his legal education at Harvard and clerked for Louis Brandeis. He then joined Covington \& Burling in Washing-

${ }^{15}$ For Cohen's career, see William Lasser's excellent biography, Benjamin $V$. Cohen: Architect of the New Deal (New Haven: Yale Univ. Press, 2002).

${ }^{16}$ A New Deal insider later related that at the time of the Destroyer Deal, Cohen and Cohen's partner, Thomas "Tommy" Corcoran, "were as intimate and important a part of the Administration as any cabinet officer or Presidential adviser-and much more so than most of them." Samuel I. Rosenman, Working With Roosevelt (New York: Harper, 1952), 114.

17 Harold L. Ickes, The Secret Diary of Harold L. Ickes: The Lowering Clouds, 19391941 (New York: Simon and Schuster, 1954), 3:230 \& 235. For example, that summer Cohen wrote the initial draft of the Democratic Party's platform for the 1940 Fall election.

${ }_{18}$ Ickes, Diary, note 17 above, at 657, 22 June 1941 entry (quoting Jackson). Similarly, New Dealer, later Justice William O. Douglas thought, "Ben was the best and most intelligent man in the New Deal." William O. Douglas, Go East, Young Man (New York: Random House, 1974), 369. In early 1940, respected columnist Joseph Alsop, speculated that Cohen and his good friend Thomas Corcoran might leave government and establish their own law firm and that Jackson might become the "senior partner" in the firm of "Jackson, Corcoran and Cohen." Joseph Alsop to Sidney Olson, 12 January 1940, Joseph Alsop Papers, Library of Congress, Washington, DC.

${ }^{19}$ See David S. McLellan, Dean Acheson: The State Department Years (New York: Dodd, Mead \& Co., 1976). 
ton. Acheson was a life-long Democrat, and early in the New Deal, President Roosevelt appointed him Undersecretary of the United States Treasury. After a well-publicized falling out with the president over monetary policy, Roosevelt forced him to resign in $1933 .{ }^{20}$ For the rest of the decade, he practiced law with the Covington firm. In 1940, he was a capable and respected forty-seven-year-old attorney with over twenty years of practice experience at the highest level. Throughout his adult life, Acheson was deeply interested in international relations. He later served as Assistant Secretary and then Undersecretary of State, and he became Secretary of State in 1949.

Newman A. Townsend ${ }^{21}$ is the least known, major participant in the drafting of Jackson's Destroyers-for-Bases opinion, but Townsend was an experienced and capable attorney. Like Jackson, Cohen, and Acheson, he was a political lawyer. He grew up and was educated in North Carolina where he served in various capacities as a legislator, executive counsel to the governor, and judge on the Superior Court. Jackson described him as "a hard-headed, conservative, and forthright former judge."22 Judge Townsend, as his coworkers called him, came to Washington with the New Deal in 1934. By 1940, he was a "high-ranking Justice Department attorney who usually wrote opinions for the Attorney General."23 In 1940, he was an experienced fifty-eight-year-old attorney who had been practicing law for thirty four years.

The present article is the first installment of an in-depth study of Attorney General Jackson's role in advising the president prior to our entry into World War II. Future installments will consider other incidents related to providing military aid to Great Britain, ${ }^{24}$ Jack-

${ }^{20}$ See Dean Acheson, Morning and Noon (Boston: Houghton Mifflin, 1965), ch. 9.

${ }^{21}$ See William Powell, "Townsend, Newman Alexander," Dictionary of North Carolina Biography, ed. W. Powell (Chapel Hill: Univ. of North Carolina Press, 1996), 6:49-50.

22 Jackson, "Final Draft,", note 6 above, at 95. Accord, Oral History interview with Bernard Bernstein (1975): 10, Harry S. Truman Library ("Judge. . . Townsend was an old Government lawyer, quite able and had a high prestige."). In a rough draft of Jackson's Destroyer Article, he described Townsend as a "counselor on whom I often relied." Jackson, " Draft 1-16," at 26, note 6 above.

${ }^{23}$ See note 491 below.

${ }^{24}$ See, e.g., Training of British Flying Students in the United States, 40 Op. Atty Gen. 58 (1941). 
son's continuing, but ultimately unsuccessful, efforts to curtail the government's conduct of illegal wire taps, ${ }^{25}$ his opinion that the President had implied constitutional authority to resolve a strike at the North America Aviation Company by seizing control of the company's plant, ${ }^{26}$ and perhaps others. ${ }^{27}$

The bulk of the present article is an historical analysis of the lawyering process that led to Jackson's destroyers-for-bases opinion. After laying out the destroyer deal's political, military, and legal context, the article turns to the Roosevelt Administration's initial efforts to avoid legal problems by enabling private corporations to sell airplanes and army weaponry across the Atlantic. ${ }^{28}$ The Administration then tried to use this model to transfer PT boats to the British but encountered a buzz saw in Congress and had to cancel the deal. ${ }^{29}$ The PT-boat fiasco culminated in Attorney General Jackson informally advising that a specific act of Congress outlawed the sale of naval vessels to belligerents. For a variety of reasons, President Roosevelt decided in early August that fifty destroyers should be transferred to the British. Jackson's informal advice regarding the PT boats stood in the president's way, but Benjamin Cohen had written a lengthy memorandum in July distinguishing destroyers from PT boats..$^{30}$ In early August, Cohen and Dean Acheson fine-tuned Cohen's memorandum and published their rewrite in the New York Times. ${ }^{31}$ Jackson then reconsidered the whole issue, distinguished the cancelled PT-boat deal, and rendered a formal opinion that the destroyers could be transferred. ${ }^{32}$

${ }^{25}$ See Neal Katyal \& Richard Caplan, "The Surprisingly Stronger Case for the Legality of the NSA Surveillance Program: The FDR Precedent," Stanford Law Review 60 (2008): 1023.

${ }^{26}$ Statement of Attorney General Robert Jackson, ca. 10 June 1941, reprinted in 89 Cong. Rec. 3992 (5 May 1943).

${ }^{27}$ There is an amusing comic-opera episode in which the President pressured Jackson to accomplish the deportation of a German femme fatale and spy, Princess Stephanie Maria Veronika Juliana von Hohenlohe. See That Man, note 6 above, at 70-71; Martha Schad, Hitler's Spy Princess: The Extraordinary Life of Stephanie Von Hohenlohe (Stroud, Gloucestershire: Sutton, 2002).

${ }^{28}$ See notes 76-144 below and accompanying text.

${ }^{29}$ See notes $145-231$ below and accompanying text.

${ }^{30}$ See notes 281-355 below and accompanying text.

${ }^{31}$ See notes $380-430$ below and accompanying text.

${ }^{32}$ See notes $432-572$ below and accompanying text. 
The present article concludes with an essay on certain discrepancies and lacunae in Jackson's later descriptions of the process. ${ }^{33}$ Then the essay draws upon the historical process to begin discussing the relationship from an attorney's point of view between traditional legal analysis and extralegal political judgment. ${ }^{34}$ in particular, the essay concludes that the traditional principles of legal analysis and professional responsibility do not provide an adequate model for understanding and judging the process of providing legal advice to the president.

To reach a realistic understanding of the destroyer deal, judgments must be made about Jackson's intentions and what he knew when he rendered his final decision. In particular, the present article makes a case that in respect of one technical but crucial legal issue Jackson rendered an opinion that was contrary to the law and that he knew was contrary to the law.

Judging a person's intentions or what a person believes can be fraught with difficulties, and when the judgment concerns events over a half century old, the difficulties are multiplied. Yet we make judgments about others every day, and so it is in the case of Jackson's opinion. There is no direct evidence that Jackson knowingly rendered erroneous legal advice. Certainly, Jackson never said so. Nevertheless, there is a wealth of circumstantial evidence indicating that Jackson was wrong and that he knew so.

The present article's purpose is not to bury Jackson in condemnation. To the contrary, the article concludes that his misrepresentation of the law on one technical issue was proper and that he should be praised for it. Some will disagree.

\section{NEUTRALITY AND MILITARY AID}

Throughout the summer of 1940, President Roosevelt's firm desire to support the British against the Germans never wavered. Nevertheless, as the saying goes, "tis many a slip twixt the cup and the lip." Effectively implementing his firm desire was severely complicated by a daunting array of national security problems, raw domestic political considerations, and a complex and partially inter-

\footnotetext{
${ }^{33}$ See notes 573-626 below and accompanying text.

${ }^{34}$ See notes $627-710$ below and accompanying text.
} 
locking array of statutes and international law principles. In terms of national security, there was a definite possibility that Germany would prevail in Europe and turn its might on the Western Hemisphere. ${ }^{35}$ The basic dilemma was whether to retain weaponry, especially destroyers, for future use by the United States or forestall a German victory by transferring weaponry to the British for immediate use against the Germans. The national security picture was further complicated by the political fact that some influential members of Congress and millions of Americans opposed providing significant aid to the British. These isolationists feared that the nation would be sucked into the European conflagration. Moreover, many wanted to reserve American weaponry for the American Army and Navy. Finally, domestic and international law seemed to preclude aiding the British or at least to require the President to obtain specific Congressional approval for aid to the British with the consequence that an unruly Congress would have to re-work the complex calculus of national security and political parameters.

After the Germans blitzed Poland in September, 1939, they had settled into a Sitzkreig, or Phony War. The British and the French on one side and the Germans on the other more or less stared at each other across national boundary lines. ${ }^{36}$ In the late spring, there was every reason to expect that the war might play out something like World War I with the Germans battling against the British and French along the western front. ${ }^{37}$ All this changed in early May when the Germans brought their blitzkrieg to the western front. In just a few days, they outflanked the Maginot Line, isolated most of the British army on the French coast around Dunkirk, and drove

\footnotetext{
35 The United States feared German incursions into Latin America as well as a direct attack on North America. See Leutze, Bargaining, note 7 above, at 86 . See also notes 303-04 below and accompanying text.

36 The significant exceptions were the German conquests of Norway and Denmark in the late spring of 1940.

37 See, e.g., Joseph Alsop \& Robert Kinter, American White Paper: The Story of American Diplomacy and the Second World War (New York: Simon \& Schuster, 1940), 80 ("the war [might] develop into a prolonged stalemate"). In writing this book, the authors had the complete cooperation of the President and the Department of State. See Ickes, Diary, note 17 above, at 290-91. Most of the German military leaders "anticipated a costly stalemate, as had happened in World War I." Gerhard L. Weinberg, A World at Arms: A Global History of World War II (New York: Cambridge Univ. Press, 2005) 109.
} 
deep into France. Notwithstanding these early successes, some people thought that the French army could absorb the initial onslaught. Before the fall of France, supplying the British with destroyers may have seemed a relatively low priority. Certainly, the British were in no immediate danger of invasion. When Churchill first asked for destroyers on May 15, ${ }^{38}$ Roosevelt refused..$^{39}$ As late as June 12, an "authoritative source [Treasury Secretary Morgenthau]" told the British that, "the President is not convinced that [the British] need for destroyers is serious." 40

The national security picture changed after the Germans briefly consolidated their gains and launched a decisive attack on the French army in early June. Churchill reluctantly concluded that France might very well surrender in the near future and told President Roosevelt as much on June $12 .{ }^{41}$ At the same time, Churchill clung to a hope that British and French troops might "fall back on the Atlantic" and maintain a toe-hold of resistance on the Continent. ${ }^{42}$ These improbable hopes were dashed when the Germans marched into Paris on June 14, and France surrendered on June 22. Britain now stood alone.

With the British facing a likely German invasion, destroyers became vital. At the same time, the American national security calculus suffered a similarly dramatic shift. There was now a significant possibility that the British would be knocked out of the war. ${ }^{43}$

${ }^{38}$ Telegram of 15 May 1940, quoted and discussed in Finest Hour, note 4 above, at 345-46 and in notes 240-45 below and accompanying text.

${ }^{39}$ President Roosevelt to Winston S. Churchill, 17 May 1940, Churchill War Papers, note 1 above, 2:69-70.

40 Lord Lothian to Winston S. Churchill, 12 June 1940, Churchill War Papers, note 1 above, 2:304. The day before, Morgenthau told Arthur Purvis, the head of the British purchasing mission, "to call a spade a spade, [allied destroyer losses] do not seem to impress us, the President to be exact." Telephone conversation transcript, 11 June 1940, Morgenthau Diaries, note 23 above, Book 271, p. 219.

${ }^{41}$ Winston S. Churchill to President Roosevelt, 12 June 1940, Churchill War Papers, note 1 above, 2:307-08. See generally Finest Hour, note 4 above, ch. 26.

42 See Finest Hour, note 4 above, at 543. On June 11, Churchill wrote Roosevelt, "Our intention is to have a strong army fighting in France for the campaign of 1941." Winston S. Churchill to President Roosevelt, 11 June 1940, Churchill War Papers, note 1 above, 2:287.

${ }^{43}$ In late May, Churchill and his Cabinet had seriously considered but rejected a negotiated peace with Hitler. See Reynolds, Creation, note 7 above, at 103-06; Leutze, Bargaining, note 7 above, ch.4; Kershaw, Fateful Choices, note 7 above, ch. 1. 
Churchill later quipped that in late June and well into July, "the Americans treated us in that rather distant and sympathetic manner one adopts towards a friend one knows is suffering from cancer." ${ }^{44}$ During this bleak interval, President Roosevelt wrote in private, "I always have to think of the possibility that if these destroyers were sold to Great Britain and if, thereupon, Great Britain should be overwhelmed by Germany, they might fall into the hands of the Germans and be used against us." 45 Similarly, Assistant Secretary of State Adolph Berle thought, "it seems plain that our job is to collect the strongest and solidest defense force we can, and not to fritter away small detachments [of destroyers] to the other side of the Atlantic." 46

These daunting national security problems were further complicated by raw domestic politics. There was serious opposition in the public and in Congress to aiding the British in their fight against the Germans. In a passage that Jackson eventually struck from his unpublished article on the Destroyer Deal, Jackson bluntly explained

Another complicating factor was that the President was in the midst of a campaign. Opposition aroused by his foreign policy might unseat him and undo his works. There was much raw material that could be worked up for the purpose-the always latent anti-British sentiments of our large and

\footnotetext{
${ }^{44}$ Leutze, Bargaining, note 7 above, at 120 (quoting Churchill).

45 Franklin D. Roosevelt to Harold L. Ickes, 6 July 1940, quoted in Reynolds, Creation, note 7 above, at 119-20. See also, Ickes, Diary, note 17 above, at 200. During the final few weeks before the fall of France, Churchill was confronted with a similar dilemma when the French pleaded for more squadrons of the Royal Air Force. If the British committed more squadrons, the planes and pilots might be lost and be unavailable for the coming Battle of Britain. See Gilbert, Finest Hour, above, note 4, at 340-41, 346-47, 456-58, 470-71, \& 506-07; Michael Korda, With Wings Like Eagles (New York: Harper, 2009), 93-119 (a somewhat uncomplimentary view of Churchill). Roosevelt told Attorney General Jackson about Churchill's problem and "added that some similar decisions might come to confront us in the future the way things were going in Europe." Reminiscences of Robert H. Jackson, 884-85, Columbia University Oral History (quoting Roosevelt).

${ }^{46}$ Adolph A. Berle, Navigating the Rapids, 1918-1971, ed. B. Berle and T. Jacobs (New York: Harcourt Brace Jovanovich, 1973), 314 (diary entry of 15 May 1940). Accord, Breckinridge Long, The War Diary of Breckinridge Long: Selections from the Years 1939-1944, ed. F. Israel (Lincoln: Univ. of Nebraska Press, 1966), 123. The British Foreign Office believed that Berle was "Anti-British." See Baron Stackelberg to Editor of Financial News, with annotation, 11 September 1940, Public Records Office, London: Foreign Office files, vol. 24263, p. 348. Accord Nicholas John Cull, Selling War: The British Propaganda Campaign Against American "Neutrality" in World War II (New York: Oxford Univ. Press, 1995), 95-96.
} 
powerful Irish population, smoldering anti-Semitism which caused some unspoken sympathy toward Hitler, the national feelings of the considerable German and Italian population and the Communist Party with its fellow travelers who were wholly committed to aid the axis so long as Stalin was a part of it. ${ }^{47}$

Benjamin Cohen later remembered that a "great many in Congress including good New Dealers ... were intransigent isolationists." 48

Moreover, President Roosevelt was about to embark upon a presidential campaign unprecedented in the history of America. In a tradition dating back to George Washington, no President had ever sought more than two terms. That summer, Roosevelt was seeking his party's nomination for a third term, and the Democratic Convention was to be held in mid-July. ${ }^{49}$ To further complicate the political picture, the initial front runner for the Republican nomination was Thomas Dewey, a firm isolationist. If Dewey gained the Republican nomination, any controversial decision by Roosevelt to aid the British would be a major campaign issue in the Fall. ${ }^{50}$ In late May, Interior Secretary Ickes noted in his diary, "Although I believe the President would be overwhelmingly elected today, I am not sure that the country could not be turned against him by November." 51

Finally, there were serious legal impediments to transferring military supplies and equipment to the British. Two different, but

\footnotetext{
${ }^{47}$ Jackson, Draft 1-20, at 4, note 6 above. For a slightly different version of this language, see Jackson, Draft 1-19, note 6 above, at 7 . In his Nov. 28 draft, Jackson significantly toned down this language by deleting all references to Irish Americans, anti-Semitism, German and Italian Americans, and the Communist Party. Jackson, Draft 1-22, note 6 above, at 21.

${ }^{48}$ Joseph Lash interview with Benjamin Cohen, 8 April 1974, Joseph P. Lash Papers, Box 59, FDR Library, Hyde Park, NY (the New Deal isolationists included "Wheeler, Lafollette, Bone").

${ }^{49}$ Jackson believed that the President's decision-making regarding aid to Britain was complicated by the fact that Roosevelt "was for the first time violating the two term tradition." Jackson Reminiscences, note 45 above, at 882 .

${ }^{50}$ In the event, the Republicans nominated Wendell Willkie, who supported the policy of aiding the British. Secretary Morgenthau saw Willkie's nomination as a green light for continuing a vigorous program of aid to the Allies. Note to file, 28 June 1940, Morgenthau Diaries, note 23 above, at Book 277, p. 66. Similarly, the German Charge d'Affaires in Washington was disappointed by Willkie's nomination. Thomsen to Foreign Ministry, 28 June 1940, Documents on German Foreign Policy, 1918-1945, vol. X, Ser. D (London: Her Majesty's Stationery Office, 1957), pp. 48-49.

${ }^{51}$ Ickes, Diary, note 17 above, at 191. See also ibid., 193 \& 223.
} 
partially related, kinds of law regulated the transfer of weaponry. When the European war began in 1939, the United States remained neutral, and this status entailed limits under international law to our country's right to assist the warring powers. At the same time, congressional legislation also limited the government's power to assist belligerents.

The international law of neutrality has changed significantly since 1940 and indeed was in the process of changing even then. ${ }^{52}$ When World War II began, however, powerful arguments could be made that international law virtually precluded the United States from providing military assistance to Great Britain. The regnant principle of the late nineteenth and early twentieth centuries strictly forbade neutral countries from giving military aid to a belligerent. Article 6 of the Hague Convention of 1907 starkly restated ${ }^{53}$ this accepted principle:

52 See Hersh Lauterpacht's analysis in L. Oppenheim, International Law, ed. H. Lauterpacht, 7th ed., vol. 2 (London: Longmans, Green, 1952), \$\$285-92i. For strong reaffirmations of the traditional rule of strict impartiality written before the summer of 1940, see Edwin Borchard \& William Lage, Neutrality for the United States, 1st ed. 1936, 2d ed. 1940 (New Haven, Yale Univ. Press, 1937); See also Professor Phillip Jessup to Charles C. Burlingham, 10 November 1939, Charles Burlingham Papers, Harvard Law Library. Others disagreed with Professor Borchard. At the very outset of World War II, Dean Acheson saw aid to Britain as a matter of self defense against totalitarian powers inevitably inimical to the United States:

We can see to it that those [whom the Germans have attacked] have the weapons and supplies with which to fight. Insofar as they weaken those whom we want weakened, we gain. Insofar as they are able to defeat them we gain even more.

Dean Acheson, "An American Attitude Toward Foreign Affairs, " 28 November 1939 (an address at Davenport College), Dean Acheson Papers, Truman Presidential Library, Independence, MO. For a good book-length treatment rejecting the traditional rule of strict impartiality, see Charles Fenwick, American Neutrality: Trial and Failure (New York: New York Univ. Press, 1940). Professor Fenwick supported the Destroyer Deal. "Upholds Destroyer Sale," New York Times, 18 August 1940; Charles Fenwick, Neutrality on the Defensive, 34 Am. J. Int'I L. 697 (1940).

${ }^{53}$ The Convention did not create the principle of strict neutrality. Rather, it simply restated a principle that already existed in customary international law at the beginning of the twentieth century. See Herbert Briggs, "Neglected Aspects of the Destroyer Deal," American Journal of International Law 34 (1940): 580-81; Edwin Borchard, "The Attorney General's Opinion on the Exchange of Destroyers for Naval Bases," Ibid. (1940): 694-95; Quincy Wright, "The Transfer of Destroyers to Great Britain," Ibid. (1940): 684 n. 11; Manley Hudson to Charles Culp Burlingham, 12 November 1940 (judge of Permanent Court of International Justice), Manley Hudson Papers, Harvard Law Library, Harvard University. See, e.g., Mixed Arbitral 
The supply, in any manner, directly or indirectly, by a neutral Power to a belligerent Power of warships, ammunition or war material of any kind whatever, is forbidden. ${ }^{54}$

The Pan American Maritime Neutrality Convention of 1928 reiterated this rule of strict neutrality. ${ }^{55}$ The United States was a signatory to both Conventions. ${ }^{56}$ Consistent with the Hague principle Lord Lothian, the British Ambassador, wrote in mid-May, 1940 that "international law forbids a neutral government to sell warships to a belligerent." 57

Although the principles embodied in The Hague Convention severely limited a neutral country's right to assist belligerents, international law has traditionally drawn a significant distinction between countries and individuals. Private citizens of a neutral country were free under international law to sell weaponry to belligerents, and the Hague Convention specifically provided:

A neutral power is not bound to prevent the export or transit, for the use of either belligerent, of arms, ammunitions, or, in general, of anything which could be of use to an army or fleet..$^{58}$

International law classified weaponry sold by private individuals as contraband that could be shipped from a neutral country. Contraband, however, was subject to seizure by belligerents. ${ }^{59}$ Of course, as a matter of domestic policy, a country might restrict its private merchants' ability to sell arms to a belligerent. In a series of neutrality statutes enacted in the 1930s, the United States went further than

Tribunal, 23 July 1926, discussed and quoted in Green Hackworth, Digest of International Law (Washington, DC: Government Printing Office, 1940), at 7:271-72; Statement of Netherlands Minister of Foreign Affairs (1916), discussed and quoted in ibid., at 578-79.

${ }^{54}$ Hague Convention XIII, Art. 6, 36 Stat. 2415, 2428.

55 Pan American Maritime Neutrality Convention of 1928, Art. 16 (a), Treaties and Other International Agreements of the United States of America, 1776-1949, comp. C. Bevans (Washington, DC: Dept. of State, 1969), at 2:726.

5636 Stat. 2415.

57 Lothian to Howden Smith, 17 May 1940, reprinted in 89 Cong. Rec. 2137-38 (1943). Lothian was specifically discussing a proposal that Great Britain purchase old destroyers from the United States. Ibid.

58 Ibid, art. 7. For the United States practice, see Hackworth, Digest, note 53 above, $\S 684$.

${ }^{59}$ See Hackworth, Digest, note 53 above, $§ \S 612-21$. 
international law required. ${ }^{60}$ These acts, however, played no role in the Destroyers-for-Bases Deal.

Notwithstanding private individuals' general license to sell contraband, international law placed a significant limitation on some types of private sales. In response to the wars of the French Revolution, the United States adopted a principle of neutrality that American ports could not be used to fit out privateers that would sail against a belligerent's merchant marine.$^{61}$ In the late nineteenth century, this principle attained the status of accepted international law after the arbitration in Geneva of the United States' claim against Great Britain regarding the Confederate raider Alabama. ${ }^{62}$

During the American Civil War, the British government allowed a private shipyard to build the cruiser Alabama, and she committed considerable depredations on American shipping in an around-theworld cruise. ${ }^{63}$ After the war, the two countries agreed to submit the matter to arbitration ${ }^{64}$ and further agreed that the arbitral panel should resolve the dispute using what became known as The Three Rules of Washington. ${ }^{65}$ Under these rules,

A neutral Government is bound,-

First, To use due diligence to prevent the fitting out, arming, or equipping within its jurisdiction, of any vessel which it has reasonable ground to believe is intended to cruise or carry on war against a Power with which it is at peace..$^{66}$

${ }^{60}$ See Robert A. Divine, The Illusion of Neutrality (Chicago: Univ. of Chicago Press, 1962); H. Duncan Hall, North American Supply (London: Her Majesty's Stationery Office, 1955), 39-54. For an excellent and sophisticated contemporary discussion of these neutrality statutes, see Elton Atwater, American Regulation of Arms Exports (Washington, DC: Carnegie Endowment for International Peace, 1941), 203-52.

${ }^{61}$ See generally Casto, Foreign Affairs, note 2 above.

${ }^{62}$ See L. Oppenheim, International Law: A Treatise, ed. H. Lauterpacht, 5 th ed., vol. 2 (London: Longmans, Green, 1935), §335.

${ }^{63}$ See Raphael Semmes, Service Afloat, or the Remarkable Career of the Confederate Cruisers Sumter and Alabama During the War Between the States (Baltimore: Baltimore Publishing, 1887) (written by the Alabama's captain).

${ }^{64}$ See John Bassett Moore, History and Digest of the International Arbitrations to Which the United States has Been a Party, vol. 1 (Washington: Government Printing Office, 1898), ch. XIV. For a good historical study of the Geneva Arbitration and its background, see Adrian Cook, The Alabama Claims: American Politics and AngloAmerican Relations, 1865-1872 (Ithaca: Cornell Univ. Press, 1975).

${ }^{65}$ See Lauterpacht's Oppenheim, note 62 above, at 715.

${ }^{66}$ Treaty of Washington, Art. $\mathrm{VI}$ (1871), Treaties and Other International Agreements of the United States of America, 1776-1949, comp. C. Bevans (Washington, DC: Government Printing Office, 1974), 12:173. The Rules continue: 
The Washington rules were incorporated with a slight change ${ }^{67}$ into the Hague Convention. ${ }^{68}$

The Hague principles of neutrality-especially Article 6's rule of strict impartiality ${ }^{69}$-created an intellectual dissonance in the Department of State. As late as August 28, after the United States had agreed to a direct sale of the destroyers, Secretary of State Cordell Hull, Legal Adviser Green Hackworth, and Assistant Secretary Breckinridge Long agreed in private that the sale "would be a violation of international law."70 The problem was that Hull, Hackworth, and Long had spent their entire professional lives assuming that the Hague rules were the law, and now German aggression was revealing a deep flaw in the Rules. Belgium declared itself neutral, but "she was overwhelmed and destroyed because she was isolated by virtue of her strict construction of neutrality."71

The three men concluded that as a matter of self-defense, the United States could eschew a "meticulously strict neutrality,"72 but they could not bring themselves to admit that the Hague rules were no longer international law. In their minds, the destroyer deal, "[o]f course [was] a violation of international law." ${ }^{73}$ This dissonance stemmed in part from a disinclination to depart from the Hague

and also to use like diligence to prevent the departure from its jurisdiction of any vessel intended to cruise or carry on war as above, such vessel having been specially adapted in whole or in part, within such jurisdiction, to warlike use.

Secondly. Not to permit or suffer either belligerent to make use of its ports or waters as the base of naval operations against the other, or for the purpose of the renewal or augmentation of military supplies or arms, or the recruitment of men.

Thirdly. To exercise due diligence in its own ports and waters, and as to all persons within its jurisdiction, to prevent any violations of the foregoing obligations and duties. Ibid.

67 See Lauterpacht's Oppenheim, note 62 above, at 716.

68 Hague Convention XIII, art. 8.

${ }^{69}$ See note 54 above and accompanying text.

${ }^{70}$ Long, War Diary, note 46 above, at 125 . Within the Department of State, the Legal Adviser's office tended to opt for a strict interpretation of the Hague Convention. Jay Pierrepont Moffat, Diplomatic Journal, 13 \& 14 April 1940, Moffat Papers, Houghton Library, Harvard University.

${ }^{71}$ Long, War Diary, note 46 above, at 125 . The Dutch government also followed the strict Hague rules and suffered the same fate. Ibid.

72 lbid.

${ }^{73}$ Ibid., at 126. 
rules, or perhaps Secretary Hull and his advisers lacked a vocabulary to describe a situation in which international law is in flux.

The international-law principles forbidding military aid stood squarely in the way of government efforts to assist Great Britain. How could the United States claim to be neutral when it was helping one of the warring European powers fight another? In addition to international law, the Congress had enacted legislation to implement The Three Rules of Washington. ${ }^{74}$

Finally, even if international law could be surmounted, there remained a technical legal objection to the United States transferring government weaponry like destroyers to Britain. Under the Constitution, no government property may be sold or transferred unless authorized by act of Congress. ${ }^{75}$

\section{A. Using Intermediaries: Finland}

The Roosevelt Administration first dealt with neutrality issues in the context of the USSR's invasion of Finland in $1939 .{ }^{76}$ When the Finnish government sought to buy munitions directly from the American government, the Roosevelt Administration refused. Secretary of State Hull emphatically told the Finnish ambassador, "whatever fighting was taking place and whatever it might be called in technical law, the one matter of concern in this country is that this Government does not engage in acts or utterances that might materially endanger its peace and safety by causing it to be drawn into war." ${ }^{77}$ Hull was also concerned about domestic politics. ${ }^{78}$ There

74 The Espionage Act of 1917,18 U.S.C. $\$ \$ 31-39$ (1940 códification). See notes 195-96 \& 339-44 below and accompanying text. The Espionage Act originated as part of an "Omnibus Bill" that collected many related and unrelated measures dealing with war and neutrality. See Lawrence Smith (Chief;, Neutrality Laws Unit) to Attorney General, 21 June 1940, Robert Jackson Papers, Library of Congress, Washington, DC.

${ }^{75}$ U.S. Const. Art. IV, $\S 3$. See notes $305-09$ below and accompanying text.

${ }^{76}$ See Langer \& Gleason, note 7 above, at 335-42.

77 Memorandum of conversation by the Secretary of State, 22 January 1940, in Foreign Relations of the United States, Diplomatic Papers, (Washington, DC: Government Printing Office, 1959), 1:279. See also Secretary of State to the Finnish Minister (Procope), 8 February 1940, ibid., at 287-88. Hull continued, "In these circumstances, I stated that, in my opinion, it need not be expected that this Government would sell arms, ammunition and implements of war to the Government of Finland." Ibid.

78 In private, he stated and restated "his belief that the whole political campaign of our opponents [in the coming Fall elections] will be based on the theory that 
were, however, ways for the United States to have its cake and eat it too. Secretary Hull noted that the United States "domestic market is open to ... Finland . . to purchase arms, ammunition, and implements of war."79

At about the same time, the Brewster Aeronautics Corporation was under contract to deliver Buffalo fighters to the Navy. The Navy postponed the delivery schedule, and Brewster then sold the Buffalos to Finland. ${ }^{80}$ Similarly, the Navy planned to facilitate Finland's purchase of two experimental fast boats by deferring the delivery date in its contract with Higgins Industries in New Orleans. ${ }^{81}$ In addition, Manuel Quezon, President of the Commonwealth of the Philippines, deferred delivery of two PT boats so that they could be delivered to Finland. ${ }^{82}$ Deferring delivery, however, would not work if the Navy wished to transfer weaponry that it already owned. To deal with this variation, the president authorized the Navy and War departments to sell military surplus to the neutral country of Sweden, and Sweden would then transfer the weaponry to Finland. ${ }^{83}$ in

the Administration is trying to lead the country into war." Jay Pierrepont Moffat, Diplomatic Journal, 29 January 1940, Moffat Papers, Houghton Library, Harvard University. See also Cordell Hull, The Memoirs of Cordell Hull, (London: Hodder \& Stoughton, 1948), 1:707.

${ }^{79}$ Secretary of State to the Finnish Minister (Procope), 8 February 1940, Foreign Relations, note 77 above, at 1:288.

${ }^{80}$ See L.H. Woolsey, "Government Traffic in Contraband," American Journal of International Law 34 (1940): 498 n.2.

${ }^{81}$ Transcript of telephone conversation between Treasury Secretary Morgenthau and Navy Secretary Edison, 26 February 1940, Morgenthau Diaries, note 23 above, at Book 242, p. 324. Navy Secretary Edison noted that this deferral of delivery would result in the Navy receiving "a much better boat." Ibid, Then Edison emphatically stated, "Now, the question of selling them cruisers or any boats or warships, any Scandinavian country - in fact, any country, that's just out." Ibid. (emphasis original). Edison evidently was referring to the tactic of transferring weaponry to Finland using Sweden as an intermediary. See note 83 below and accompanying text. Later in the summer, the Navy's firm desire not to part with any of its warships created significant problems for the Destroyer Deal.

82 See D. J. Callaghan to General Watson, memorandum, 9 January 1940, President's Secretary's Files, FDR Library, Hyde Park, NY.

${ }^{83}$ See Keith McFarland, Harry H. Woodring: A Political Biography of FDR's Controversial Secretary of War (Lawrence: Univ. Press of Kansas, 1975), 219; Langer \& Gleason, note 7 above, at 339-40. "The legal procedure would be for the Navy to declare the [weaponry] surplus and the Army arrange for its sale. If this could be sold to Sweden and any or all of it passed along by Sweden to Finland, it would be the quickest way for us to provide the Finns with munitions of war." Captain Puleston to Secretary Morgenthau, 19 February 1940, Morgenthau Diaries, note 23 
addition, at least fifty 75-mm artillery pieces were declared surplus and apparently sold to Finland through a private company. ${ }^{84}$

The basic idea was that using intermediaries like Brewster Aeronautics or Sweden as cut outs gave the United States plausible deniability against charges of violating the international law of neutrality. This analysis, however, was hardly persuasive. ${ }^{85}$ The Hague Convention outlawed the supply of munitions "in any manner, directly or indirectly," ${ }^{86}$ and the subterfuge of intermediaries is obviously an indirect transfer. Nevertheless, using intermediaries gave the Administration something approaching plausible deniability.

\section{B. Using Intermediaries: Army Surplus}

During the Phony War, the British and French made significant purchases of American aircraft but were relatively uninterested in purchasing other American weaponry. ${ }^{87}$ The Allied thirst for warplanes inevitably placed them in competition with the United States armed forces, and in January, President Roosevelt met with a group of top military officers and Treasury Secretary Henry Morgenthau to discuss the allocation of airplane production between the United

above, at Book 241, p. 168. See also, Captain Puleston to Secretary Morgenthau, 26 February 1940, ibid. Book 242, pp. 320-21. Of course, Sweden's transfer of arms to Finland would have violated the Hague Convention. See note 54 above and accompanying text. The Swedish plan never came to pass because Finland quickly fell to the Russian attack. McFarland, Woodring, this note, at 219.

${ }^{84}$ Mark Watson, Chief of Staff: Prewar Plans and Preparations (Washington, DC: Historical Division, Dept. of the Army, 1950), 311.

${ }^{85}$ See Woolsey, "Government Traffic," note 80 above; Borchard, Neutrality, note 52 above, at 416-17; Brigg, "Neglected Aspects," note 53 above, at 574-75 n. 22; Lawrence Preuss, "The Concepts of Neutrality and Nonbelligerency," Annals of the Am. Academy of Political and Social Society 218 (November 1941): 97, 105; Finding by Fiedler, Zarky, and Wolf (n.d. ca. May 1940) (internal memorandum by midlevel Treasury Department attorneys), Oscar Cox Papers, FDR Library, Hyde Park, NY; Atwater, American Regulation note 60 above, at 253-55. Even international lawyers favoring aid to belligerents dismissed the intermediary or cut-out model as a "subterfuge." Clyde Eagleton, "The Needs of International Law," American Journal of International Law 34 (1940): 702; Manley Hudson to Charles C. Burlingham, 12 November 1940, Manley Hudson Papers, Harvard Law Library, Harvard University; Henry L. Stimson \& McGeorge Bundy, On Active Service in Peace and War (New York: Harper, 1948), 356 ("the subterfuge was obvious, and unconcealed").

${ }^{86}$ See note 54 above and accompanying text.

${ }^{87}$ See Hall, North American Supply, note 60 above, at 105-26; Reynolds, Creation, note 7 above, at 97. 
States military and Allied purchasing agents. Morgenthau was at the meeting because the President had decided that Morgenthau rather than the War or Navy Secretaries should be in charge of facilitating the Allies' purchase of war materials. ${ }^{88}$ The latter Secretaries consistently sought to impede Allied purchases until they resigned at the President's request in June. ${ }^{89}$ Roosevelt was quite blunt at the January meeting:

The President stated that he felt that those present understood the necessity for expediting in every way possible deliveries to the Allies, that he wanted them to have his view on the subject and that the matter, if necessary, would be taken up again at a later date..$^{90}$

Notwithstanding the President's clear statement of policy, some within the army chose to impede the Allies' efforts to purchase aircraft. In mid-March, this insubordination resulted in what Secretary Morgenthau dubbed the "Battle of Washington." ${ }^{21}$ The President summoned General "Hap" Arnold, the head of the Army Air Corps, to his office for a two and a half hour discussion of "the airplane thing"92 and read him the Riot Act. If Arnold did not begin cooperating, "he would be removed as head of the Air Corps [and transferred] to Guam." ${ }^{93}$ Secretary Morgenthau gleefully told the head of the British Purchasing Commission, "The Army has got their orders." $^{\text {94 }}$

\footnotetext{
${ }^{88}$ See McFarland, Woodring, note 83 above, ch. 12.

${ }^{89}$ See ibid. In April, 1940, Woodring told a reporter that, "he [Woodring] may yet be the last isolationist left in Washington." Clapper Notebook, April, 1940, Raymond Clapper Papers, box 25, Library of Congress.

${ }^{90}$ Memorandum, 17 January 1940, Morgenthau Diaries, note 23 above, Book 236, pp. 90-91.

${ }^{91}$ Telephone transcript, 13 March 1940, Morgenthau Diaries, note 23 above, Book 247, p. 25.

${ }_{92}$ Conference transcript, 13 March 1940, Morgenthau Diaries, note 23 above, Book 247, p. 11.

${ }_{93} \mathrm{lbid}$. Morgenthau related, "the President said, 'You know,' looking at Arnold, he said, 'When people can't control themselves and their people under them, you know what we do with those kind of people? We send them to Guam." Ibid. That same day, General Arnold wrote, "It was a party at which apparently the Secretary of War and [I] were to be spanked and were spanked." Memorandum of Record by General Arnold, 13 March 1940, Henry H. Arnold Papers, Library of Congress, Washington, DC, quoted in McFarland, Woodring, note 83 above, at 213.

${ }_{94}$ Telephone transcript, 20 March 1940, Morgenthau Diaries, note 23 above, Book 248, p. 13
} 
The President was willing to be equally blunt when an attorney provided unwanted legal advice. In late May of 1940, Secretary Morgenthau wrote him about an attorney in Treasury who "has given every indication of a disposition to construe [legislation] so as to bring about a result which is wholly contrary to the policy of the administration of assisting the democracies."95 The President succinctly replied, "We cannot have such people in high places." 96 The President's solution was remarkably similar to his earlier blunt threat to General Arnold: "If you do not want to discharge him, send him to some office in the interior of a Southern State." ${ }^{\prime 7}$ Dean Acheson described his own come-to-Jesus meeting with Roosevelt in 1933 when Acheson's reading of legislation impeded the President's agenda on monetary policy: "It was a magnificent and intimidating experience." 98

When the Phony War ended in May and the Germans rolled through the Low Countries, World War II began in earnest. The miracle of Dunkirk saved the British army, but virtually all the weapons remained in France. Suddenly, the British needed American weaponry as soon as possible. Because American manufacturers could not immediately supply any significant munitions, the only available source was existing stockpiles held by the United States. ${ }^{99}$

95 F.D.R. to the Secretary of Treasury, undated attachment to memorandum dated 29 May 1940 (giving specific examples), President's Secretary's Files, FDR Library, Hyde Park, NY. The attorney, Ernest Fiedler, was "in charge of the Opinion Section of the General Counsel's Office of the Treasury Department." Ibid.

96 F.D.R. to the Secretary of Treasury, memorandum, 29 May 1940, President's Secretary's Files, FDR Library, Hyde Park, NY.

${ }_{97}$ Ibid. Roosevelt continued that if the attorney were exiled, "have some trusted person in such office report to you confidentially on what he says and does when he gets there." Ibid.

${ }^{98}$ Acheson, Morning, note 20 above, at 190. Acheson's meeting was at an early stage of his 1933 conflict with the President over manipulating the price of gold. See notes 416-27 below and accompanying text. As a young thirty-something attorney, Acheson described his encounter with the president with more bravado: Thomas Corcoran wrote that Acheson "was so excitedly mad he could hardly talk, told me he didn't give a God damn about any Treasury matters any more because he was through and had given the President $a[n]$ ultimatum that . . . He, Dean would resign." [Thomas Corcoran] to [Felix Frankfurter] (n.d.), Thomas Corcoran Papers, Box 198, folder 4, Library of Congress, Washington, DC. Other portions of this twenty five page letter make it clear that Corcoran is the author. The letter is in Corcoran's file of Frankfurter correspondence. In the end, Roosevelt demanded and received Acheson's resignation.

${ }^{9}$ Hall, North American Supply, note 60 above, at 131-35. 
Although the British needs were urgent, the State Department was not very cooperative. Interior Secretary Ickes viewed State as "a conglomeration of ambitious men consisting mainly of careerists who, because they are career men, feel no obligation to follow Administration policy." ${ }^{100}$ Even those who were not careerists were somewhat obstructive. On May 23, Undersecretary Sumner Welles met with Chief of Staff Marshall and told him a "direct sale ... would be contrary to the Neutrality Act and to international law, and that [Welles] had in mind no method for circumventing those barriers." ${ }^{101}$ When Marshall told Morgenthau about Welles' tentative advice, Morgenthau was none too pleased: "I [will] call up Sumner Welles and tell him for God's sake to give us an answer on this gun business." 102 In the ensuing telephone call, Welles reiterated his position and said that "Congress would have to take action as I see it." 103

Welles's advice on international law was at best irrelevant and at worst consciously misleading. He told Marshall and Morgenthau that a "direct sale" would violate international law, and he told Marshall that he "had in mind no method for circumventing those barriers." ${ }^{104}$ But just a few months earlier, the United States had circumvented the international law barriers by using an intermediary to transfer Buffalo fighters to Finland. ${ }^{105}$ Moreover, at the same

${ }^{100}$ /ckes Diary, note 17 above, 216 (29 June 1940 entry).

${ }^{101}$ George C. Marshall to Sumner Welles, 24 May 1940, Morgenthau Diaries, note 23 above, Book 266, p. 24. See also, George Marshall, Memorandum for the War Plans Division, 23 May 1940, The Papers of George Catlett Marshall, (Baltimore: Johns Hopkins Press, 1986), 2:223. The reference to "the Neutrality Act" apparently was to the Army Appropriations Act for 1919 discussed in notes 12426 below and accompanying text.

102 Conference transcript, 25 May 1940, Morgenthau Diaries, note 23 above, at Book 266, p. 89.

${ }^{103}$ Transcript of telephone call, 25 May 1940, Morgenthau Diaries, note 23 above, Book 266, p. 110-11.

104 See note 101 above and accompanying text.

${ }^{105}$ See notes 80-81 above and accompanying text. Nevertheless, a group of midlevel attorneys in Treasury believed that transferring surplus munitions through a private intermediary would clearly violate international law. Findings of Fiedler, Zarky, and Wolf, 3 June 1940, Oscar Cox Papers, FDR Library, Hyde Park, NY. The lead author of this memorandum was the attorney that the President said should be banished to "the interior of a Southern State." See notes 95-97 above and accompanying text. 
time that Welles was telling Marshall that he could not think of a solution to the problem, he was telling the British Ambassador that the use of an intermediary would circumvent the international law problem. ${ }^{106}$ When push came to shove, the State Department blinked and supported a limited transfer using an intermediary. State's Legal Adviser determined that at least in the case of aircraft, the Army could trade existing planes to a private company for new ones and that the old planes could then be sold by the private company to the Allies. ${ }^{107}$

Hackworth's opinion was a positive step forward. The Navy was planning to dispose of 50 Helldiver bombers through a trade-in arrangement, and Hackworth's analysis firmly supported this relatively narrow plan. ${ }^{108}$ There were, however, tremendous gaps in the opinion. The overwhelmingly predominant portion of the weapons to be transferred were not airplanes. Moreover, the plan was to sell the weaponry and not to trade them in. Finally, the Comptroller General had ruled that the trade-in authority could not be used unless the equipment was first advertised for sale. ${ }^{109}$ The weaponry were needed as soon as possible, and the advertising process would take several months. ${ }^{110}$

The day after Hackworth wrote his opinion, he dictated his analysis by telephone to Justice, and Jackson quickly annotated the opinion

\footnotetext{
106 Memorandum of conversation by the Under Secretary of State (Welles), 23 May 1940, Foreign Relations, note 77 above, at 3:3-4: If the United States transferred munitions to private companies, "the private manufacturers could sell them directly to the British Government, and there would consequently be involved no breach of the neutrality of the United States under international law."

${ }^{107}$ Green H. Hackworth, Opinion, 28 May 1940, National Archives, RG107, A1 90, Box 3C, Washington, DC. Hackworth relied upon 10 U.S.C. $\$ 1272$ (1940 codification), which allowed "airplanes, engines, parts thereof" to be traded in for "new equipment."

${ }^{108}$ Although the Navy did not have a trade-in authority comparable to the Army, Attorney General Jackson opined a week and a half later that the planes could be transferred from the Navy to the Army and then traded in. Attorney General Jackson to Secretary of the Navy, 7 June 1940, discussed in Newman Townsend, Memorandum for the Attorney General, 13 August 1940, Robert Jackson Papers, Box 88, Library of Congress, Washington, DC.

${ }^{109}$ See Secretary Woodring to President Roosevelt, 31 May 1940, National Archives, R6107, A190, Box 3C Washington, DC.

110 McFarland, Woodring, note 83 above, at 223.
} 
with a cursory "I agree with Mr. Hackworth's conclusions." 111 Jackson also told State that he thought that the Comptroller General's determinations regarding the advertising issue were "erroneous ... but [he, Jackson] has not made a study of the question."112

Notwithstanding these opinions, War Secretary Woodring cleaved to the Comptroller General's opinion, ${ }^{113}$ and President Roosevelt referred the matter to Attorney General Jackson. ${ }^{114}$ The Army wanted to use the Finland/intermediary model to effect the transfer of munitions, ${ }^{115}$ and on June 3, Acting Attorney General Francis Biddle gave an opinion on this assumption. ${ }^{116}$ Early that day, Secretary Morgenthau was very angry. He had told the Army to get the vast store of munitions ready for shipment, and the Army had delayed. Morgenthau angrily said

I'm Good and sore, and so is the President, and I've got the authority to tell them before sunset tonight, by God, they're going to do it or somebody's going to get hurt. ${ }^{117}$

An hour and a half later, he convened a meeting of himself, Welles, General Marshall, and Solicitor General Francis Biddle to work out the legal problems. ${ }^{118}$

Apparently Attorney General Jackson's duties did not allow him to participate in the meeting. Perhaps he was out of town. He delegated his authority to Biddle, and Judge Townsend aiso participated. ${ }^{119}$ That day, Biddle argued a case before the Supreme Court and came straight to the meeting in "cutaway coat and pin-striped

111 Jackson's annotation, 29 May 1940, on Green Hackworth's Opinion of 18 May 1940, National Archives, RG 107, A1 90, Box 3C, Washington, DC.

112 Cordell Hull to the President, 29 May 1940, ibid.

${ }^{113}$ Secretary Woodring to President Roosevelt, 31 May 1940, ibid.

114 McFarland, Woodring, note 83 above, at 223.

$115 \mathrm{Mr}$. Young to Secretary Morgenthau, 3 June 1940, Morgenthau Diaries, note 23 above, Book 268, p. 59.

${ }^{116}$ Acting Attorney General Francis Biddle to War Secretary Woodring, 3 June 1940, Foreign Relations, note 77 above, at 2:790-96.

${ }_{117}$ Telephone transcript, 3 June 1940, Morgenthau Diaries, note 23 above, Book 268, p. 231.

118 Henry Morgenthau to President Roosevelt, 4 June 1940, Morgenthau Diaries, note 23 above, Book 268, p. 231.

119 Telephone transcript, 4 June 1940, Morgenthau Diaries, note 23 above, Book 268, p. 196. 
trousers." ${ }^{120}$ After about an hour, most of the principals left, and the attorneys continued working on a favorable opinion till twenty past midnight. ${ }^{121}$ It was a hot day, and Biddle's "stiff shirt was wilted [and] his high formal collar was a moist rag" ${ }^{122}$ when he finally signed the opinion. Secretary Morgenthau was not surprised. He had said earlier that day that if the munitions were not shipped, "somebody's going to get hurt." He told one of his staff, "[Biddle] has got to do that. The President wants it."123

Biddle addressed the advertising issue but concentrated on the Army Appropriations Act for 1919 that forbade the government to sell surplus "guns and ammunition" to anyone other than "Governments engaged in war against any Government with which the United States is at war." ${ }^{124}$ Biddle advised that this provision was amended by the next year's appropriation act that generally authorized the Secretary of War "to sell any surplus supplies including motor trucks and automobiles now owned by [the United States] to any corporation or individual upon such terms as may be deemed best." 125 He pushed the plain meaning of the word "supplies" to its limits. The general authorization to sell "supplies" applied to guns and presumably any and all tangible personal property. The Act easily could have been construed as not superseding the very specific

\footnotetext{
${ }^{120}$ Drew Pearson \& Robert Allen, The Washington Merry-Go-Round, Elyria [Ohio] Chronicle-Telegram, June 11, 1940.

${ }^{121}$ Conference transcript, 4 June 1940, Morgenthau Diaries, note 23 above, Book 268, p. 220.

122 Drew Pearson \& Robert Allen, The Washington Merry-Go-Round, Elyria [Ohio] Chronicle-Telegram, June 11, 1940.

123 Conference transcript, 4 June 1940, Morgenthau Diaries, note 23 above, Book 268 , p. 204. Three days before Biddle gave his opinion, Cordell Hull cabled the American ambassador to France that a "way has been now found by which the War and Navy Departments can transfer to private manufacturers for immediate sale to the British and French governments such munitions desired by them." Cordell Hull to William Bullit, 30 May 1940, William Bullit Papers, Box 72-1812, Yale University.

${ }^{124}$ Acting Attorney General Francis Biddle to Secretary of War, 3 June1940, Foreign Relations, note 77 above, at 2:790-91; An Act Making appropriations for the support of the Army for the fiscal year ending June thirtieth, nineteen hundred and nineteen, 65th Cong., 2 d sess., chap 143, Pub. L. No. 65-193, 40 Stat. 845, 850.

${ }^{125}$ An Act Making appropriations for the support of the Army for the fiscal year ending 1920, and for other purposes 66th Cong. 1st sess., ch. 8, Publ. L. No. 66-7, 41 Stat. 104, 105.
} 
limitations of the 1919 Appropriations Act, ${ }^{126}$ but Biddle rendered an opinion that facilitated President Roosevelt's national security policy. The Appropriations Act argument allowed Biddle to go far beyond Hackworth's opinion, which was limited to airplanes. Under Biddle's analysis, all types of munitions could be transferred by a simple sale.

Biddle then turned to the Comptroller General's decision that sales of the surplus equipment required a publicly advertised auction. The Acting Attorney General noted that the 1920 appropriations act allowed the War Secretary "to sell any surplus supplies ... upon such terms as may be deemed best." ${ }^{127}$ A reasonable construction of the word "terms" would be that it referred to the terms of the contract of sale. The Attorney General, however, construed "terms" to include the procedure for selecting the purchaser. ${ }^{128}$ An internal official history of Lend-Lease described the legal machinations behind the June, 1940 sale of surplus equipment as "a curious legal situation." ${ }^{129}$

After a short night's sleep, Biddle got up bright and early the next day to explain his conclusions to the War Department. One witness related that, "Biddle was quite persuasive." 130 Biddle, himself, was a little more florid. He laughingly said when some "old women ... kicked about the Comptroller General. I said, to hell with the Comp-

\footnotetext{
${ }^{125}$ For example, there is the canon of statutory construction that repeals by implication are not favored. United States v. Burroughs, 289 U.S. 159 (1933). Accord Watt v. Alaska, 451 U.S. 259 (1981). Moreover, the government's basic plan was to transfer weaponry to Great Britain in violation of the Hague Convention and the Pan American Maritime Neutrality Convention. See notes 53-57 above and accompanying text. Acts of Congress usually are construed not to violate international law. See Murray v. The Charming Betsy, 6 U.S. (2 Chranch) 64 (1804); Curtis A. Bradley, "The Charming Betsy Canon and Separation of Powers: Rethinking the Interpretive Role of International Law," Georgetown Law Journal 86 (1998): 479. A group of mid-level attorneys of Treasury concluded that the repeal-by-implication and the Charming Betsy canons were relevant. They believed that the repeal-byimplication argument could go either way. Findings by Fiedler, Zarky, and Wolf, 3 June 1940, Oscar Cox Papers, FDR Library, Hyde Park, NY.

127 Biddle opinion, note 124 above, at 791.

128 Jbid.

129 Warren F. Kimball, The Most Unsordid Act: Lend-Lease, 1930-1941 (Baltimore: Johns Hopkins Press, 1969), at 45 (quoting the internal history).

${ }_{130}$ Conference transcript, 4 June 1940, Morgenthau Diaries, note 23 above, Book 268, p. 197.
} 
troller General, I'm the Attorney General."131 The surplus items were then quickly sold to Britain for a little over 37 million dollars using the United States Steel Export Co. as a cut out. ${ }^{132}$

Although Biddle's opinion was quite expansive, it did not give the Secretary of War carte blanche. The 1920 act only allowed the sale of "surplus supplies," and more significantly, it only authorized the sale of items possessed by the War Department on July 11, 1919. ${ }^{133}$ The issue of surplus was a factual issue that could be left to the more or less pliant judgment of the War Department. ${ }^{134}$ The issue of possession in 1919 was also a factual issue, but it could not be fudged. The opinion, however, sufficed to implement the President's plans because the immediate issue was whether a tremendous stockpile of weaponry left over from World War I could be transferred to the British. President Roosevelt was satisfied. As soon as he learned of the opinion, he immediately penned a short note to Morgenthau: "Can you hurry this up?"135 He gleefully wrote an acquaintance that the Acting Attorney General's "excellent ruling" was being implemented immediately. ${ }^{136}$

131 Telephone transcript, 4 June 1940, Morgenthau Diaries, note 23 above, Book 268, p. 206. Similarly, a few weeks later, when Jesse Jones, head of the Reconstruction Finance Corp., was balking at complying with a different Attorney General opinion, Morgenthau advised someone "to shove the Attorney General's opinion down Jones' throat and see what happens." Telephone transcript, 25 July 1940, Morgenthau Diaries, note 23 above, Book 286, p. 245. For background, see Kimball, Unsordid Act, note 129 above, at 75-76.

${ }^{132}$ Contract between United States Steel Export Co. and His Majesty's Government in the United Kingdom, 18 June 1940, reprinted in Hall, North American Supply, note 60 above, App. I, at 497. See ibid., at 132-38; Goodhart, Fifty Ships, note 7 above, at 61-62. See also Watson, Chief of Staff, note 84 above, at 310 \& 312.

133 An Act Making appropriations for the Support of the Army, 66th Cong., 1st sess., ch. 8, Pub. L No. 66-7, 41 Stat. 104, 105.

${ }^{134}$ See notes 140-42 below and accompanying text. But see Aaron Fellmeth, "A Divorce Waiting to Happen: Franklin Roosevelt and the Law of Neutrality, 19351941," Buffalo Journal of International Law (1997): 464-65.

135 President Roosevelt to Morgenthau, 4 June 1940, Morgenthau Diaries, note 23 above, Book 268, p. 232. Two days later, Roosevelt was "delighted. . . that [the] material [was] 'ready to roll,"' and told Secretary Morgenthau to "[g]ive it an extra push every morning and every night until it is on board ship!" F.D.R. to Secretary of the Treasury, memorandum, 6 June 1940, President's Secretary's Files, FDR Library, Hyde Park, NY.

${ }^{136}$ Franklin Roosevelt to Lewis Douglas, 7 June 1940, in F.D.R., His Personal Letters, ed. E. Roosevelt, (New York: Duell, Sloan, and Pearce, 1947), 2:1037-38. 
Although the President was pleased with Biddle's "excellent ruling," isolationists were not. A month later, Senator Clark noted in passing, "I realize, as most everyone else, that it is a very poor President who could not get a ruling he wanted from his own Attorney General. I know of only one instance in the history of our Government to the contrary, and Andrew Jackson dismissed that Attorney General." 137 Nevertheless, Biddle's opinion sufficed to allow the deal to go forward.

The 1919 time limit might have become a significant limitation once the old World War I stockpiles were exhausted, but plans were already afoot to moot this problem. At the same time that Acting Attorney General Biddle was drafting his opinion, the Army gave a congressional committee a proposed amendment that by-passed the 1919 time requirement. ${ }^{138}$ The Senate added this obscure measure to pending legislation in early June, a Committee of Conference approved it on June 21, and the amendment became law on July $2{ }^{139}$ This new provision did not authorize the Navy to dispose of surplus equipment, but the assumption was that the Navy could transfer its equipment to the Army. ${ }^{140}$

13786 Cong. Rec. 7927 (June 11, 1940). Senator Clark probably was referring to Biddle's opinion and perhaps Jackson's June 7 advice on the Helldivers. The story of President Jackson's firing of Attorney General John Berrien is rather murky. See Baker, Conflicting Loyalties, note 8 above, at 23-24 \& 192. Nevertheless, Jackson clearly fired Berrien.

138 Telephone transcript, 3 June 1940, Morgenthau Diaries, note 23 above, Book 268, p. 167; second Telephone transcript, 3 June 1940, ibid., at 182.

${ }^{139}$ H.R. Rep. 2685, 76th Cong., 3d sess. (committee of conference). The Congress formally enacted the legislation on July 2. An Act to expedite the strengthening of the national defense, 76th Cong., 3rd sess., Ch. 508, 54 Stat. 712. On June 3, General Marshall told Secretary Morgenthau, "l've got the amendment to the law now before the Committee today." Telephone transcript, 3 June 1940, Morgenthau Diaries, note 23 above, Book 268, p. 167. Although the amendment was written in obscure terms, Congress knew that its purpose was to enable the transfer of more modern surplus munitions to Great Britain. Senator Clark bitterly complained that the amendment was "an evasion of international law and of the Neutrality Act." 86 Cong. Rec. 7927, 7928, \& 7930 (June 11, 1940). See also Briggs, "Neglected Aspects," note 53 above, at 573 .

140 Treasury General Counsel Foley advised CNO Stark that the "Navy has the exchange power still and you can turn your stuff over to the Army and it becomes surplus for the Army." Conference transcript, 3 July 1940, Morgenthau Diaries, note 23 above, Book 279, p. 142. On June 7, Attorney General Jackson formally advised the Navy that this process was lawful. See note 108 above and accompanying text. 
The Administration immediately relied upon Biddle's opinion to open the floodgates for a vast shipment of supplies to the Allies. In the late winter and spring of 1940, the Army was generally opposed to transferring its existing equipment to other nations. Army Chief of Staff General George Marshall explained "that most of the equipment, even the most antiquated, on the surplus list was of value for training purposes." 141 The German successes in May, however, caused the Army to reconsider its opposition. Under pressure from the White House, the Army came up with an extensive list of items that could be released. The list included a half million rifles, a hundred million rounds of ammunition, hundreds of cannon and mortar, and tens of thousands of machine guns. ${ }^{142}$ After the Acting Attorney General's opinion, the Army agreed to classify vast stockpiles of weaponry as surplus, "if the War Department could be assured that we would not be called upon for a general mobilization within two years." ${ }^{143}$ The matter was referred to the President who approved the transfer. ${ }^{144}$

\section{Using Intermediaries: The Mosquito Boat Fiasco}

The Roosevelt Administration now had two legal models for transferring weaponry to Great Britain. One approach, based upon the Acting Attorney General's opinion, was to declare existing government stockpiles of weaponry as surplus and then transfer the surplus to private concerns that would in turn sell the weaponry abroad. Another approach was the Finland model in which the government would cancel or delay contracts for yet-to-be-delivered weapons so that the producer could sell them to the British. If these models worked for artillery, small arms, ammunition, and aircraft, why not use them to transfer naval vessels to Great Britain? The deferred-delivery model had already been used to transfer fast boats and PT boats to Finland. ${ }^{145}$ In late May, the Administration tentatively

\footnotetext{
141 Memorandum of conversation, 21 February 1940, quoted in Watson, Chief of Staff, note 84 above, at 303.

142 /bid., at 309.

${ }^{143}$ Walter B. Smith, Memorandum for Information of Chief of Staff, 11 June 1940, quoted in ibid., at 312.

144 Ibid.

${ }^{145}$ See notes 81-82 above and accompanying text.
} 
decided to transfer twenty torpedo boats to the British. ${ }^{146}$ The boats were frequently called mosquito boats.

These mosquito boats were the prototypes for the PT boats that later saw extensive service in the Pacific. ${ }^{147}$ With their shallow draft and high speed, they would have been quite useful for patrolling the waters along the British coast. ${ }^{148}$ In addition, the British defense plan against an actual invasion called for a large screen of smaller patrol boats more or less the size of the PT boats and "[behind] these patrolling craft . . . flotillas of destroyers."149 Twenty three of the PT boats were being built by the Electric Boat Company (Elco) in New Jersey, and the plan was for the Navy to defer delivery of twenty of the boats with the understanding that Elco would then sell the deferred boats to the British. ${ }^{150}$ Elco would fulfill their contract with the United States by delivering better boats at a later date.

146 See Conference transcript, 30 May 1940, Morgenthau Diaries, note 23 above, Book 267, p. 367; Assistant Navy Secretary Lewis Compton to Captain C.W. Fisher, 4 June 1940, PT/L4 (390119-1), National Archives, Washington, DC. See also, 86 Cong. Rec. 8777 (Sen. Walsh). The original plan was to release both torpedo boats and submarine chasers, and the deal was sometimes described as involving ten or more of each. See, e.g., 86 Cong. Rec. 8775 (1940) (Sen. Walsh). This erroneous reference to submarine chasers is repeated in many subsequent accounts. See, e.g., Jackson, Final Draft, note 6 above, at 93; Lasser, Cohen, note 15 above, at 220; Fellmeth, "Divorce," note 132 above, at 467 . See also Bruff, Bad Advice, note 8 , above, at 35 . The submarine chasers, however, evidently were dropped from the deal because the delivery of the sub chasers was delayed until all the torpedo boats were completed. See Lewis Compton to Senator Walsh, June 1940, quoted in 86 Cong. Rec. 8781 (1940). Then the deal was changed to twenty torpedo boats. See Assistant Navy Secretary Lewis Compton to Captain C.W. Fisher, 11 June 1940, PT/L4 (390119-1) National Archives, Washington, DC.

${ }^{147}$ See Roger Kafka \& Roy Pepperburg, Warships of the World, Victory Edition (New York: Cornell Maritime Press, 1946) (PT 21-44), at 223.

148 Motor Torpedo Boats, 11 June 1940 ("a most important arm in the defense of the southern coast of England"), Morgenthau Diaries, note 23 above, Book 271, p. 245. When the United States entered the war a year and a half later, the very PT boats that would have been sold to the British were very effective in the Philippine archipelago. Kafka \& Pepperburg, note 147 above, at 223-24.

149 Winston Churchill to Generals Ironside and Gill, 10 July 1940, Churchill War Papers, note 1 above, 2:496.

150 See Assistant Navy Secretary Lewis Compton to Captain C.W. Fisher, 4 \& 11 June 1940, memoranda, PT/L4 (390119-1) National Archives, Washington, DC. 
The torpedo-boat deal sparked fireworks at a cabinet meeting on June $7 .^{151}$ The episode painfully illustrates the perils of giving a client legal advice that the client does not want to hear. On that day, Jackson formally advised the Navy that Navy Helldivers could be transferred lawfully to the Army with the understanding that the Army would transfer the dive bombers to private manufacturers who would sell them to the Allies. ${ }^{152}$ That same day, the Attorney General and the president lunched together, and the two men immediately proceeded to the cabinet meeting. ${ }^{153}$ When they arrived, the president lit the fireworks' fuse by announcing that "the transfer [of the torpedo boats] had been cleared legally by the Attorney General."154 The president had also discussed the matter with former Attorney

151 Shogan describes the cabinet meeting as taking place on June 4 (Shogan, Hard Bargain, note 7 above, at 87-88), but Ickes' Diary indicates that the meeting was on June 7. Ickes, Diary, note 17 above, at 202. Accord Reminiscences of Henry Agard Wallace, at 1144, Columbia University Oral History.

152 Attorney General Jackson to Secretary of the Navy, 7 June 1940, discussed in Newman Townsend, Memorandum for the Attorney General, 13 August 1940, Robert Jackson Papers, Box 88, Library of Congress, Washington, DC.

153 Robert Jackson, Untitled Schedule of Meetings May-Sept. 1940 (n.d.), Robert Jackson Papers, Library of Congress, Washington, DC. In his oral history, Jackson related, "The serious matters between the President and departments were usually taken up privately. For my own part, I had lunch with him frequently, and during the lunch hour we discussed his problems and mine." Jackson Reminiscences, note 45 above, quoted in, Philip Kurland, "Robert $H$. Jackson," The Justices of the United States Supreme Court, 1789-1969: Their Lives and Major Opinions, ed. L. Friedman and F. Israel (New York: Chelsea House in association with Bowker, 1969), $4: 2543,2559$.

154 James Farley, Jim Farley's Story the Roosevelt Years (New York: Whittlesey House, 1948) (quoting Vice President Garner), at 242-43. Farley's account of a conversation with Vice President Garner, who was at the meeting, conflates the torpedo-boat deal with the destroyer deal, but his reference to Navy Secretary Edison pretty clearly establishes that Garner was talking about the June 7 cabinet discussion of the torpedo-boat deal. Accord, Jackson, Draft 1-16, at 18, note 6 above; ("more likely" a reference to June 7 Cabinet meeting); Gerhart, America's Advocate, note 13 above, at 215. Agriculture Secretary Wallace recorded that the discussion involved transferring "the planes at Buffalo to the Allies." Wallace Reminiscences note 151 above, at 1144 . These were the Curtis Wright Helldivers, (see notes 18185 below and accompanying text), which were to be delivered to the Curtis Aeroplane Company at Buffalo, New York. Proposed Release, 7 June 1940, Morgenthau Diaries, note 23 above, Book 270, p. 1. Although the PT boat deal and the Helldiver deal both involved the transfer of navy property to Great Britain, the legality of two deals involved distinctly different legal analyses. In particular, the restrictions of the Espionage Act of 1917 applied to vessels but not airplanes. See note 195 below and accompanying text. 
General Homer Cummings. ${ }^{155}$ Almost immediately, Navy Secretary "Charlie Edison spoke up and said the transfer was being arranged over his protest." 156 Edison explained that "the Judge Advocate General of the Navy [Rear Admiral Walter B. Woodson] had said that the transaction was illegal." 157 The president did not want to hear about it and became "impatient." $158 \mathrm{He}$ "didn't like what Edison said."159 Nevertheless, express advice that a project is illegal cannot be ignored. The project has to be changed (perhaps even cancelled), or the advice has to be rejected as erroneous. President Roosevelt chose the latter course. He scornfully condemned the Judge Advocate General as a "sea lawyer" and "an old admiral whose mental capacity I knew personally." 160 Instead of listening to the old "sea lawyer," Roosevelt ordered Edison "to get his law from the Attorney General." 161

The president's essential position was that the Navy attorney who opined that the torpedo-boat deal was illegal was incompetent. Nor did Roosevelt leave it there. He went on to recommend that the Navy's Judge Advocate General should be sent "away on a vacation [perhaps to Guam or the interior of a Southern State ${ }^{162}$ ]." 163 Then "if the man next in line [at JAG] didn't know any more law, he should

\footnotetext{
155 Apparently the President told Cummings that he would "make use of every legal trick in order, by circumventing the Neutrality Law, to furnish the Allies with every possible material help." Chargé d'Affaires Thomsen to German Foreign Ministry, 11 June 1940, German Documents, note 50 above, at 547. Cummings related the conversation to a friend who passed it on to the German Embassy. Ibid. The year before Roosevelt told Secretary Morgenthau "to do everything . . . that we can get away with" in helping the Chinese against the Japanese. Robert Dallek, Franklin D. Roosevelt and American Foreign Policy, 1932-1945 (New York: Oxford Univ. Press, 1979) (quoting FDR), at 247.

${ }^{156}$ Farley's Story, note 154 above, at 242-43 (quoting Vice President Garner).

157 Ickes, Diary, note 17 above, at 202. Accord, Wallace Reminiscences, note 149 above, at 1144 .

158 Ickes, Diary, note 17 above, at 202.

${ }^{159}$ Farley's Story, note 154 above, at 243 (quoting Vice President Garner).

${ }^{160}$ Ickes, Diary, note 17 above, at 202 (quoting the President). The Navy JAG had been the president's naval aide a few years earlier. See That Man, note 6 above, at 212.

161 lbid.

162 See notes 95-97 above and accompanying text.

${ }^{163}$ Ickes, Diary, note 17 above, at 202. Accord, Wallace Reminiscences, note 151 above, at 1144 .
} 
also be sent on a vacation, and so on down the list." 164 A month later, Secretary Woodring told a reporter that the president had said, "if couldn't get an opinion that would permit a certain thing to be done, 'I'd [Roosevelt] get a couple of other lawyers who would give me the opinion that I wanted." 165

These were harsh words, but Edison did not take the hint. Perhaps he was emboldened by the fact that he had resigned his office a few days earlier to be effective June $24 .{ }^{166}$ He persisted in urging that the deal was illegal. The President, however, would have none of it. He had made up his mind "to use every legal trick" possible to help the British. ${ }^{167}$ Finally, Roosevelt gave Edison a flat order: "forget it and do what I told you to do."168 Vice President Garner later told Postmaster General James Farley "that after the meeting, Attorney General Jackson came to me and said that in spite of the statement made [by the President] that he [Jackson] had approved the sale and held it to be legal, he had not made such a decision." 169

\footnotetext{
${ }^{164}$ Ickes, Diary, note 17 above, at 202. Accord, Wallace Reminiscences, note 151 above, at 1144 .

165 Clapper Notebook, July 1-16, 1940 (quoting the president), Raymond Clapper Papers, Box 25, Library of Congress.

166 Press Release, 4 June 1940, Morgenthau Diaries, note 23 above, Book 268, pp. 285-86.

167 See note 155 above.

$168 \mathrm{Ibid}$. (quoting the President). It has been suggested that the President was, in effect, telling Edison "to forget legality and follow orders." Fellmeth, "Divorce," note 134 above, at 468; Bruff, Bad Advice, note 8, above, at 35. This suggestion, however, is quite inconsistent with Vice President Garner's recollection of the meeting (see note 154 below and accompanying text) and with Secretary Icke's recollection that the President told Edison "to get his law from the Attorney General." See note 161 above and accompanying text.

${ }^{169}$ Farley's Story, note 154 above, at 243, (quoting Garner). The Vice President continued, "I told [Jackson] that he should have so declared himself at the Cabinet meeting and I say now he should have said he had not held the transfer to be legal, if he did not." Ibid.

This particular story's accuracy is suspect. Farley was not present during the Garner/Jackson conversation. Instead, Farley was relying upon his memory of what Garner told him eight years earlier. When Jackson began writing his law review article, he first wrote, "I have no recollection" of this conversation. Jackson, Draft 116, note 6 above, at 18; Jackson, Draft 1-24, note 6 above, at 18. In his final draft, he emphatically denied Farley's account:
}

The other error . . . is that the President said that the transfer had been cleared legally by the Attorney General. I could hardly pass in silence, nor forget, so false a statement had it ever been made. My recollection is quite 
Roosevelt gave his blunt order on Friday, June 7, and the next Tuesday, the Navy was finalizing the deal. ${ }^{170}$ Although the train had clearly left the station, the locomotive jumped the tracks six days later. In an executive meeting of the Senate Naval Affairs Committee, a senator asked a naval officer (probably Chief of Naval Operations Admiral Harold Stark ${ }^{171}$ ) about rumors ${ }^{172}$ that the Navy might transfer some of its destroyers to the British. The officer replied that nothing had been done along that line. ${ }^{173}$ Indeed, "he vehemently said that the Navy would never give up its destroyers; that we would not be equipped for war for two years." ${ }^{174}$ The Committee was not

to the contrary: the President said the transfer had not been cleared, and that was what brought about my informal expression of view.

"Jackson, Final Draft," note 6 above, at 244 n. 62 (emphasis original). Jackson also suggested that perhaps Vice President Garner misheard or misunderstood the discussion. Ibid. Except for the confusion of destroyers for mosquito boats, the contemporaneous notes of Secretaries Ickes and Wallace confirm Farley's account of the cabinet meeting. See notes 154-68 above and accompanying text. Ickes and Wallace, however, were not present at Jackson's post-cabinet meeting with Garner.

Apparently the Helldiver deal (see notes $181-85$ below and accompanying text) was discussed as precedent for the torpedo-boat deal. See note 154 above. The torpedo-boat deal, however, implicated the Espionage Act of 1917, which did not apply to airplanes. See note 195 below and accompanying text. When the president and Jackson lunched that day, Jackson probably advised the President of his legal opinion on the Helldiver deal. The President then conflated the two at the cabinet meeting.

${ }^{170}$ Assistant Navy Secretary Lewis Compton to Captain C.W. Fisher, 11 June 1940, PT/L4 (390119-1), National Archives, Washington, DC.

171 See John Blum, From the Morgenthau Diaries: Years of Urgency 1938-1941 (Boston: Houghton Mifflin, 1965), at 2:161: "On the Hill, [Admiral Stark] was asked the question about selling destroyers. 'Did they [the United States Navy] need them all?' and he answered yes."

172 Given Secretary Edison's opposition to the torpedo-boat deal, it is tempting to believe that he leaked the deal to the Senate Committee. If so, he was a very clever leaker because the rumors were based upon a New York Times article. New York Times, 12 June 1940, p. 16. Moreover, the rumors were about destroyersnot torpedo boats. As early as May 29, Secretary Hull told a reporter that the British needed destroyers from the United States but that the Navy "can't spare them" and that a transfer "would take legislation." Raymond Clapper's notes of an interview with Cordell Hull (May 29, 1940), Raymond Clapper papers, box 9, folder 6 , Library of Congress.

173 See 86 Cong. Rec. 8775 (21 June 1940).

$174 \mathrm{Ibid}$., at 8777 . See also, ibid., at 8775 . The Acting Navy Secretary said essentially the same thing in private. Meeting transcript, 12 June 1940, Morgenthau Diaries, note 23 above, Book 272, p. 40. 
entirely satisfied with this firm response and resolved to make formal inquiry as to precisely what Navy property was being transferred to the British. ${ }^{175}$

To mix metaphors, the locomotive hit the fan the next day on June 14. When Acting Navy Secretary Compton learned that the Committee was planning a formal inquiry, he telephoned the Committee's chair, Senator Walsh, and told Walsh about the torpedoboat deal. That same day, Walsh hailed Compton and the naval officer before the Committee. It was a "stormy session", 176 and Walsh "catechized them at length as to what property ... had been disposed of"177 through sale or deferred delivery dates. Compton then described the torpedo-boat deal.

Senator Walsh, who "was extremely pro-Irish,"178 pressed Compton on the legal authority for transferring the boats to Britain, and Compton replied that the Navy's general authority to amend contracts sufficed. ${ }^{179}$ This approach was the same tactic that the Navy had used earlier to enable the transfer of Brewster Buffalos to Finland. ${ }^{180}$ Like the Buffalos, the boats belonged to the private manufacturer until the United States took possession. Deferring the delivery date enabled Elco to sell the boats elsewhere and to comply with the Navy contract by delivering replacement boats at a later date.

17586 Cong. Rec. 8775 (21 June 1940).

${ }^{176}$ Washington Times Herald, June 19, 1940, reprinted in 86 Cong. Rec. 8607 (10 June 1940).

17786 Cong. Rec. 8775 (21 June 1940).

178 Jackson Reminiscences, note 45 above, at 902.

17986 Cong. Rec., at 8779 . See also Lewis Compton to [Senator Walsh], 14 June 1940 , reprinted in ibid., at 8777-78. Compton noted that in addition to the torpedo boat deal, the Navy had used the deferment of delivery tool to enable the Du Pont Powder Co. to sell the British naval gun powder. 86 Cong. Rec., at 8775 . See also, Memorandum of Conference, 28 Febrary 1940, Morgenthau Diaries, note 40 above, Book 243, pp. 159-60.

${ }^{180}$ See note 80 above and accompanying text. The Congress was aware of the Brewster Buffalo transaction. See 86 Cong. Rec. 8775 (21 June 1940) (Walsh). The Navy had also planned to use contract deferrals to enable the French to purchase Grumman F4F-3 fighters. See Captain M.A. Mitcher to President's Liaison Committee, memorandum, 30 April 1940, Morgenthau Diaries, note 23 above, Book 259, p. 12. The most precise precedent was the transfer of Higgins boats to Finland. See note 81 above and accompanying text. 
Compton also told Walsh's committee that the Navy had enabled the transfer of fifty Douglas SBC-4 Helldivers to the Allies. ${ }^{181}$ The tactic of deferring delivery dates only worked for weaponry that had yet to be delivered to the United States, so the government had to rely upon a different, and quite convoluted, analysis for the Helldiver deal. Compton explained ${ }^{182}$ that although the Navy lacked authority to transfer the planes directly to a private party, an existing statute authorized the Navy to transfer "equipment of every character" to the Army. ${ }^{183}$ Another statute authorized the Army to trade in "aeroplanes [to private companies] in part payment for new equipment." ${ }^{184}$ Compton did not mention that the Army expressed a wish to retain some of the Helldivers and that Morgenthau's response was, "Nuts to the Army!"185

One can imagine Secretary Edison's thoughts when he learned of the Committee's displeasure. He had warned the president about problems with the deal just a week earlier, and the president ignored his advice. Even worse, the president rebuked him at the cabinet meeting in blunt and impolite terms. There can be no doubt that Edison gloated over Senator Walsh's fury. But he did not publicly exult in the president's misfortune. Instead, he immediately dashed off a note to the White House. He warned that "Sen. Walsh is reported to me as in a towering rage about sale of Navy stuff to Allies." ${ }^{186}$ Even worse, Walsh "is threatening to force legislation prohibiting sale of anything. . . Whole committee in lather." 187

\footnotetext{
18186 Cong. Rec., at 8775-76. The Navy enabled the transfer on June 8. See Mr. Young to Secretary Morgenthau, memorandum, 9 August 1940, Morgenthau Diaries, note 23 above, Book 291, pp. 4 \& 5. Helldiver was a generic name for Navy dive bombers. The SBC- 4 bombers were older model biplanes and not to be confused with the Douglas Dauntless Helldivers that delivered the decisive blows at the Battle of Midway. See Barret Tilman, Helldiver Units of World War II (London: Osprey Publishing, 1997).

182 Lewis Compton to [Senator Walsh], 14 June 1940, reprinted in $86 \mathrm{Cog}$. Rec., at 8777-78.

${ }^{183} 10$ U.S.C. $\$ 1274$ (1940 codification).

$184 \mathrm{Ibid}$. $\$ 1272$.

${ }^{185}$ Conference transcript, 5 June 1940, Morgenthau Diaries, note 23 above, Book 269, p. 157.

${ }^{186}$ Charles Edison to The White House, 14 June 1940, President's Secretary's Files, FDR Library, Hyde Park, NY.

${ }^{187} \mathrm{lbid}$. (emphasis original).
} 
Notwithstanding the committee's "lather" and Senator Walsh's "towering rage," bureaucratic inertia briefly kept the torpedo-boat deal on course. As word of Walsh's anger became public knowledge, the Administration's initial, probably reflexive, reaction was to stay the course. ${ }^{188}$ But the deal was dead in the water. Chairman Vinson of the House Naval Affairs Committee added a provision to a naval expansion bill that would specifically outlaw the PT boat deal and all other sales of naval vessels: ${ }^{189}$ At the same time, Senator Walsh decided to draft his own provision forbidding the proposed transfer of weaponry, including vessels, to the British. Like the Vinson Amendment, the Walsh Amendment specifically forbade using contract deferrals to enable transfers to the British. ${ }^{190}$ The Administration saw the writing on the wall, and on June 21, Walsh told the Senate that the torpedo boat deal had already been cancelled. ${ }^{191}$

While Senator Walsh was raging over the torpedo-boat deal, Attorney General Jackson was reviewing the deal's legality. On June 20, Judge Townsend gave Jackson an internal memorandum concluding that the Navy's old "sea lawyer" was correct. ${ }^{192}$ With only a cursory analysis, Townsend very briefly stated that the deal violated a criminal statute dating from World War $\mathrm{I}^{193}$ and might violate an

188 The Navy Department and the White House press secretary initially reported that the deal would go through. See New York Times, 19 June 1940, p. 8 (Navy Department); (bid. 20 June 1940, p.11 (White House).

${ }^{189}$ Washington Post, 20 June 1940, p. 1. Vinson's proposed amendment provided, "no vessel ship or boat now in the United State Navy or being built therefor shall be disposed of by sale, charter, or otherwise, or scrapped, without the consent of Congress." Ibid. (emphasis added), quoting the Amendment. The Vinson Amendment was enacted on July 19 in a less restrictive form. See note 309 below and accompanying text.

190 The Walsh Amendment specifically applied to ships owned by the United States and also ships "which have been contracted for." An Act to expedite national defense, and for other purposes, 76th Cong., 3rd sess., ch. 440, \$14(a), 54 Stat. 676,681 . More significantly, it provided that "no military or naval weapon, ship, boat, aircraft, munitions, supplies, or equipment, to which the United States has title. . . shall hereafter be transferred ... . in any manner whatsoever unless the Chief of Naval Operations in the case of naval material and the Chief of Staff of the Army in the case of military material, shall first certify that such material is not essential to the defense of the United States." Ibid.

19186 Cog. Rec. 8777 (21 June 1940) (Sen. Walsh).

192 Newman A. Townsend to Attorney General, 20 June 1940, Robert H. Jackson Papers, Box 88, Library of Congress, Washington, DC. Of course, Townsend made no mention of the Navy JAG's prior opinion.

19318 U.S.C. $\$ 33$ (1940 codification). 
ancient criminal statute dating from the end of the War of 1812.194 His memorandum covered these two statutes in eight lines and then took four pages to treat international law constraints.

The most obvious obstacle to the deal was a section of the Espionage Act of 1917 that provided

During a war in which the United States is a neutral nation, it shall be unlawful to send out . . . of the United States any vessel built, armed, or equipped as a vessel of war, ... . with any intent ... that such vessel shall be delivered to a belligerent nation. . . ${ }^{195}$

This statute was a Congressional implementation of The Three Rules of Washington. ${ }^{196}$

As contemplated, the deal called for deferring the delivery of the torpedo boats with the understanding that Elco would complete their construction and sell the boats to the British. In the statute's language, Elco would have "built, armed, or equipped [the boats] with . . . intent . . . that [the boats] . . be delivered to a belligerent nation." Accordingly, Townsend stated in his memorandum to Jackson, "I think that the sale and delivery is expressly prohibited by [the Espionage Act]."197

Townsend also believed that a provision of the Neutrality Act of $1794^{198}$ presented problems. This older statute provided

Whoever, within ... the United States, fits out and arms . . . any vessel with intent that such vessel shall be employed in the service of any foreign prince ... to cruise, or commit hostilities against the . . citizens, or property of

19418 U.S.C. $\$ 23$ (1940 codification). Actually, the statute originated even earlier. See Briggs, "Neglected Aspects," note 53 above, at 576 n. 28.

19518 U.S.C. $\S 33$ (1940 codification). Violators of the statute were subject to fine, imprisonment, and forfeiture of the vessel. Ibid. $\$ 36$.

${ }^{196}$ See notes 61-68 below and accompanying text. In a memorandum written the day after Townsend's memorandum, another DOJ attorney noted that the Espionage Act provision was enacted in response to foreign governments chartering ships "loaded with coal or food and [supplying] belligerent ships on the high seas." Lawrence Smith, Chief, Neutrality Laws Unit to Attorney General, 21 June 1940, Robert Jackson Papers, Library of Congress, Washington, DC.

197 Townsend Memorandum, note 192 above, at 1. John Foster Dulles, who later served President Eisenhower as Secretary of State, agreed. He told a reporter, "some things done violate law-such as turning over mosquito boats-violate law based on Alabama case." Clapper Notebook, June 19-July 1, 1940, Raymond Clapper Papers, box 25, Library of Congress.

${ }^{198} 18$ U.S.C. $\$ 23$ (1940 codification). Townsend traced the act back to an 1818 statute, but the 1818 statute was in turn based upon the Neutrality Act of 1794 . 
any foreign ... state ... with whom the United States are at peace ... shall be fined not more than $\$ 10,000$ and imprisoned not more than three years. ... 199

Townsend was not as certain about the applicability of this ancient law and simply noted, "There is a question whether [the deal] is not prohibited by [the old Neutrality Act]." 200

Most of Townsend's memorandum dealt with international law principles related to the proposed torpedo-boat deal. Although the Hague Convention Article 6 forbade the United States to "supply . . . indirectly" warships to a belligerent, ${ }^{201}$ Townsend did not mention Article 6, probably because the deal followed the Finland/army-surplus model and the Helldiver model of enabling Elco, a private corporation, to sell the boats to Britain. Instead, he devoted all of his attention to Article 8's prohibition against fitting out vessels. ${ }^{202} \mathrm{His}$ analysis consisted of a lengthy three and a half page excerpt from Hersh Lauterpacht's fifth edition of Oppenheim's International Law. ${ }^{203}$ Townsend was uncertain what to make of the extended discussion in Oppenheim, or perhaps he did not want to take a clear position regarding international law. "As usual," he concluded, "the internation law on the subject is somewhat indefinite." 204

Attorney General Jackson's view of the torpedo-boat deal's legality is a moving target that changed as many as three times in June. At the June 7 cabinet meeting, Roosevelt announced that Jackson had cleared the deal apparently based upon the Helldiver precedent. ${ }^{205}$ There is evidence, however, that Jackson had not ruled specifically on the mosquito boats. ${ }^{206}$ Perhaps in response to the opinion of the Navy Judge Advocate General and certainly in response to Senator Walsh's strident objections, Jackson asked Judge Townsend to take a look at the Deal. Townsend orally advised Jackson on either June 19 or June 20 that the deal was illegal under the

\footnotetext{
19918 U.S.C. $\$ 23$ (1940 codification).

200 Townsend Memorandum, note 192 above, at 1.

201 See note 54 above and accompanying text.

202 See notes 66-68 above and accompanying text.

${ }^{203}$ Lauterpacht's Oppenheim, note 62 above, at 574-79.

204 Townsend Memorandum, note 192 above, at 5.

${ }^{205}$ See notes $154 \& 169$ above.

${ }^{206}$ See note 169 above.
} 
Espionage Act and perhaps under the old Neutrality Act. In any event, at the June 20 Cabinet meeting, Jackson gave an "informal opinion" 207 that the deal would violate the Espionage Act. Earlier in the morning, the White House Press Secretary telephoned Secretary Morgenthau that "Bob Jackson thinks it's absolutely illegal." 208 After the Cabinet meeting, Jackson told Agricultural Secretary Wallace that the deal "was clearly illegal." 209 Whether Jackson actually used the words "absolutely" or "clearly" is unclear. These strong adverbs may be the speakers' untutored impression of Jackson's oral pronouncements.

Notwithstanding two hearsay statements that Jackson thought the deal was "absolutely" and "clearly" illegal, Jackson's final opinion was neither absolute nor clear. When Townsend delivered his formal written opinion on June 21, Jackson pondered Townsend's memorandum, consulted with the President, ${ }^{210}$ and decided to fine tune Townsend's analysis.

Townsend had unequivocally concluded that the deal "is expressly prohibited by" the Espionage Act. Jackson, however, thought that the issue was not so clear. He used equivocal language. The statute did not "expressly" prohibit the deal. Instead, Jackson opted for softer language bordering on ambivalence: the deal "would seem to be prohibited by [the Act]." ${ }^{211}$ As for the old Neutrality Act, Jackson retained Townsend's equivocal statement that "there is also a

207 Jackson, Final Draft, note 6 above, at 94.

208 Note to files, 20 June 1940, Morgenthau Diaries, note 23 above, Book 274, p. 177.

${ }^{209}$ Wallace Reminiscences, note 151 above, at 1161: "Jackson told me later that this action was clearly illegal and he wished the President would stop doing tricky things like this." In a preliminary draft of his Destroyer Article, Jackson wrote, "the law seemed to me plain." Jackson, Draft 1-20, note 6 above, at 27.

${ }^{210}$ See Memorandum of telephone conversation between Townsend and Acting Secretary Compton, 24 June 1940, attached to Lewis Compton Memorandum, 25 June 1940 (PT/L4) (390119-1), National Archives, Washington, DC).

${ }^{211}$ See ibid. The next day, Oscar Cox in Treasury asked Judge Townsend for "a copy of the Attorney General's statement." Oscar Cox, diary entry, 24 June 1940, Oscar Cox Papers, FDR Library, Hyde Park, NY. Townsend immediately sent a copy with language that tracked his final oral advice to the Navy. Undated statement attached to Oscar Cox to Judge Townsend, 25 June 1940, Oscar Cox Papers, FDR Library, Hyde Park, NY. 
question whether [the deal] is now prohibited by [the old Neutrality Act]."212

Townsend then telephoned DOJ's informal advice to the Navy Department on June $24 .{ }^{213}$ In keeping with the subtly of the equivocal language, "would seem," and "there is a question," Townsend emphasized that the advice "is not an opinion, it is merely a statement." ${ }^{214} \mathrm{He}$ insisted that "FDR didn't ask for an opinion. He wanted it in the form of a statement and that is what I am preparing on this." 215 Apparently, Jackson did not want to render a formal opinion on the Espionage Act.

Some have uncritically assumed that Jackson's informal opinion was "the President's only reason for [cancelling the deal]." ${ }^{216}$ Jackson, however, did not actually advise that the deal was illegal. Rather, he stated that the deal "would seem to be prohibited" by one act and that "there is a question whether [it] is now prohibited by" another act. ${ }^{217}$ With sufficient encouragement, Jackson easily could have advised that the deal was lawful. ${ }^{218}$

212 See memorandum of telephone conversation between Townsend and Acting Secretary Compton, 24 June 1940, note 206 above. The written statement that Judge Townsend sent to Treasury the next day uses the identical language except that the written statement uses the word "not" rather than "now." See Undated Statement, discussed in note 211 above.

213 Memorandum of telephone conversation, note 210 above.

214 Ibid. quoting Townsend.

215 Ibid.

216 See David Barron \& Martin Lederman, "The Commander in Chief Clause at the Lowest Ebb," Harvard Law Review 121 (2008): 1044 (quoting New York Times); Langer \& Gleason, note 7 above, at 521-22; New York Times, 25 June 1940. See also, Goodhart, Fifty Ships, note 7 above, at 88-89; Shogan, Hard Bargain, note 7 above, at 93; Woolsey, "Government Traffic," note 80 above, at 499; Briggs, "Neglected Aspects," note 53 above, at 571. Others have taken a more cynical view. See Fellmeth, "Divorce," note 134 above, at 468-69 ("The only reason Roosevelt never consummated the sale was that he failed to hide the transaction from Congress; when Walsh threatened to cause trouble, Roosevelt had to back down and call off the deal."). On June 20 , Walsh reported that the deal had been cancelled and noted that the Attorney General "has given no opinion ... upon this matter." 86 Cong. Rec., at 8778.

217 Telephone conversation (emphasis added), note 210 above.

${ }^{218}$ For example, the Espionage Act was aimed at sending out a "vessel." Jackson might have concluded that torpedo boats were boats and not vessels. The Navy disagreed with this possible interpretive solution. See Lewis Compton to the Chairman, Senate Committee on Naval Affairs, 14 June 1940, reprinted in 86 Cong. Rec., at $8777-78$. Nevertheless, the distinction would not necessarily have been sophistic 
Jackson probably wanted to have his cake and eat it too. As a good lawyer, he probably did not want to restrict unduly his client's future options. He tried to leave a technical loop hole that would allow a later revision. If he later changed his mind, he could dismiss

The Espionage Act implemented Hague Convention Article 6, and a strong argument could be made that the gravamen of Article 6 violation was the mounting of a naval expedition from a neutral country. During World War I, the State Department determined that a contract for motor launches 75 feet in length were not vessels under the Hague Convention. See Hackworth, Digest, note 53 above, at 415-17. See also 86 Cong. Rec. 8779 (21 June 1940) (Sen. Walsh: "one naval officer questioned the use of the word 'vessels.' He said these [PT boats] were boats, not vessels"); ibid., at 12654 (Sen. Walsh). Accordingly, the Espionage Act might be construed in pari mutuo with the Hague Convention as not applying to small PT boats.

A second approach would likewise have construed the statute in pari mutuo with international law. When Professor Alexander Sack looked at the issue a few months later, he read the Three Rules of Washington as forbidding neutral countries from allowing their ports to be used as a base of operations. Alexander Sack to Editor (23 October 1940), New York Times, Oct. 27, 1940. Sack argued that the word "after" in the Espionage Act was ambiguous and that the Act therefore could be construed as allowing a transfer so long as the boats did not engage in combat operations until they first had arrived in and departed from a belligerent port. Alexander Sack to Editor (15 November 1940, New York Times, 17 November 1940. See also, Alexander Sack to Editor (26 December 1940), New York Times, 29 December 1940. Professor Sack was a capable law professor at the New York University Law School. Sarah Ludington, "The Dogs that Did Not Bark: The Silence of the Legal Academy during World War II," Journal of Legal Education 60 (2011): 41417.

In addition to the above two interpretations of the Espionage Act, the Administration could have made the deal lawful by changing the underlying facts. The terms of the torpedo boat deal might have been changed to provide for a direct transfer of the boats from the United States, itself, to Great Britain. If so, the government would have had a powerful argument that the Espionage Act was inapplicable. See notes 345 \& 529-42 below and accompanying text. See also H. Hansen to [Oscar] Cox, June 29, 1940, note 231 below.

A final approach would have been to have Elco complete construction of the boats under the Navy's contract and then defer delivery of the boats to the Navy. This restructuring would seem to be a mere sleight of hand but nevertheless would have been consistent with Jackson's subsequent formal destroyer opinion. Syndicated national columnist, Bruce Catton thought so. See, e.g., "Loophole May Permit Sale of Torpedo Boats," Maryville (MO) Daily Forum, 26 September 1940; "White Committee Sees Way Around Jackson Ruling," Hope (AK) Star, 24 September 1940. As late as August 17, President Roosevelt told Canadian Prime Minister Mackenzie King that he was planning on taking possession of the PT boats and then striking them from the Navy Register. Mackenzie King to Winston Churchill, 18 August 1940 (relating an Aug. 17 conversation), Public Records Office, London: Foreign Office files, 371 , vol. 24, 242, pp 45-48. 
his earlier advice as merely a tentative statement about what might "seem" to be the law.

An astonishing June 20 discussion at the Treasury suggests a possible reason for Jackson's apparent change in position from his June 20 advice in which he gave some the impression that the deal was "absolutely" or "clearly" illegal. When Edward Foley, Treasury's General Counsel, told Morgenthau that the torpedo-boat deal violated the Espionage Act, which was a criminal statute, the Treasury Secretary immediately responded, "I had nothing to do with it." ${ }^{219}$ Morgenthau must have realized how ridiculous his denial sounded, ${ }^{220}$ and almost immediately he added, "I mean to this extent, there is nothing in writing." 221 After Assistant Treasury Secretary Herbert Gaston ${ }^{222}$ explained, "There is a perfect record made here for prosecution of [Elco],"223 Morgenthau asked, "Seriously, can you see any way in which I am personally liable?"224 Morgenthau got some solace from Gaston's explanation of the statute. With relief he said, "Then it is on [ElCo]." ${ }^{225}$ But his relief was short lived. The immediate response was, "And anybody who conspired with them to do it."226 General Counsel Foley pointed out, however, that there was no prob-

${ }^{219}$ Conference transcript, 20 June 1940, Morgenthau Diaries, note 23 above, Book 274, p. 291.

220 Three weeks earlier, he had told his General Counsel to "tell Purvis [Chief of British purchasing] tomorrow he can have twenty of those speed boats from the Electric Boat Company, twenty." Conference transcript, 30 May 1940, Morgenthau Diaries, note 23 above, Book 267, p. 374.

221 Conference transcript, 20 June 1940, Morgenthau Diaries, note 23 above, Book 274, p. 291

222 I have been unable to ascertain whether Gaston was an attorney.

223 /bid., at 292. The day before, Gaston had consulted with Oscar Cox in the Treasury General Counsel's Office, and Cox told him that the deal was illegal, and "the only thing they could think of was that the ships should be sold to Portugal, which was rather flimsy." Henry Gaston, memorandum of day's activities, 19 June 1940 Herbert Gaston Papers, Box 1, FDR Library, Hyde Park, NY.

224 Conference transcript, 20 June 1940, Morgenthau Diaries, note 23 above, Book 274, p. 293.

225 Ibid., at 294.

226 Ibid. Morgenthau immediately interjected, "I never talked to Electric Boat ... Is it a crime to bring it to the President's attention?" Ibid. Senator Walsh took the position that those in government who approved the torpedo boat deal and who knew about the Espionage Act were subject to prosecution. 86 Cong. Rec. 8778 (21 June 1940). Senator Vandenberg took the position that ignorance was no excuse. Ibid. 
lem "when we have got the Attorney General." 227 Foley continued, "That is the only way the criminal laws of the United States can be enforced, through the Department of Justice."228 Perhaps Jackson softened his opinion four days later to assuage fears of criminal liability.

The most astonishing part of the conversation at the Treasury Department was a breathtaking assertion by General Counsel Foley that he had known that the deal was probably illegal but did not tell anyone. When Morgenthau asked, "Well, you fellows passed on this, didn't you?", Foley responded, "No. We were all ready, but nobody asked us." 229 More specifically, he claimed, "I knew about the statute and I didn't raise the question because [Assistant Navy Secretary Compton] said he had already done it." ${ }^{230}$ By this, Foley meant that he thought that the Navy had worked out the legal difficulties. Foley recalled that "[Oscar] Cox [, a Treasury attorney,] was sitting next to me and I said, 'You had better keep quiet. Let's not ask them how they did it.'"231

The General Counsel's attempted self-justification is appalling. Perhaps he did not know about the Espionage Act and was lying to hide his ignorance. Conversely, if he actually knew about the legal

227 Conference transcript, 20 June 1940, Morgenthau Diaries, note 23 above, Book 274, p. 293.

228 Ibid.

229 lbid., at 292.

230 Ibid., at 292-93. It might be argued that Foley meant that the boats had already been transferred, but the boats had yet to be completed. Nor is this conjecture consistent with Foley's next statement. See note 229 below and accompanying text.

$231 \mathrm{lbid}$., at 293. On the morning of June 19, when word of Senator Walsh's criticism of the torpedo-boat deal was reported in the morning's newspaper, Assistant Secretary Gaston immediately consulted with Oscar Cox about the problem, and late that afternoon Cox briefed Treasury General Counsel Foley on the legal issues. Oscar Cox Diary, 19 June 1940, Oscar Cox Papers, FDR Library, Hyde Park, NY). Foley was more or less out to sea on the matter, so Cox had to "refresh" the General Counsel's memory. Cox reminded Foley that he had earlier told the General Counsel that "I [Cox] was very doubtful about the legal power of both the Navy and the electric boat Company to ... sell the boats to the British Government." Ibid. Cox almost immediately referred the matter to one of his assistants who responded on June 29 with a careful twelve-page analysis, which contended that neither the Espionage Act nor the old Neutrality Act applied to actions taken by the government, itself. H. Hansen to [Oscar] Cox, June 29, 1940, Benjamin Cohen Papers, box 8 , destroyers-for-bases folder, Library of Congress, Washington, DC. 
difficulty, his silence was willful misconduct that did significant harm. If he had raised the issue in the private meetings of the principals, the problem of the Espionage Act could have been resolved before the President's explosion at the cabinet meeting and before Senator Walsh's explosion in Congress.

\section{THE DESTROYERS}

Before, during, and after the short life and death of the torpedoboat deal, the British were constantly imploring the United States to transfer a number of obsolescent destroyers to the Royal Navy. Destroyers were crucial to the British war effort. In September 1939, just a week after the war began, Churchill, who was then First Sea Lord, reviewed the Royal Navy's construction program and "was distressed to see that till the end of 1940, i.e., sixteen months, we only receive ten destroyers."232 A week later, the shortage of destroyers was still on Churchill's mind. He told the War Cabinet, "we should do everything in our power to purchase destroyers from the United States." ${ }^{233}$ Churchill was not worried about the vessels' quality. He wanted ships in the water: "even if we could only secure 20 of their old vessels, they would be of the greatest assistance to us."234

The "old vessels" Churchill had in mind were part of a large fleet of destroyers built some thirty years earlier at the end of World War I. They were obsolescent the day they were launched, ${ }^{235}$ but as a matter of fiscal frugality, many were still in service some twenty years later in 1940. The ships were usually called "flush deckers" or "four stackers." ${ }^{236}$ Although the old destroyers could sail across the

\footnotetext{
${ }^{232}$ Winston Churchill to Admiral Pound, 11 September 1939, reprinted in Churchill War Papers, note 1 above, 1:73, 74.

${ }^{233}$ War Cabinet minutes, 18 September 1939, reprinted in ibid. 109, 110. Senior American naval officers anticipated this request as early as November 1939. Admiral C.C. Bloch to CNO Harold Stark, letter, 1 November 1939, Harold Stark Papers, Naval Historical Center.

234 /bid.

${ }^{235}$ Conway's All the World's Fighting Ships, 1922-1946, ed. R. Chesneau (London: Conway Maritime Press, 1980), at 86.

${ }^{236}$ Arnold Hague, Destroyers for Great Britain: A History of 50 Town Class Ships Transferred From the United States to Great Britain in 1940, rev. ed. (Annapolis: Naval Institute Press, 1990), at 7.
} 
Atlantic, they did not have good range. Their armament was woefully inadequate, carrying "only four guns apiece, and ... no anti aircraft guns." 237 Nor were they particularly seaworthy. They had an exorbitantly wide turning radius and suffered from frequent steering failures; they were wet ships below decks; and the forward guns could not be manned in a head sea. ${ }^{238}$ Nevertheless, they could float and move, and their guns usually could fire. The British Director of Anti-Submarine Warfare bluntly explained: "Any destroyer that could steam, shoot, and drop depth charges was worth its weight in gold . . . in the autumn of 1940."239

After Churchill replaced Prime Minister Chamberlain in May, 1940, Churchill immediately asked President Roosevelt for destroyers. Churchill had coveted America's obsolete destroyers since the first month of the war, ${ }^{240}$ and Britain's desperate condition now lent urgency to his desire. On May 15, he pleaded to President Roosevelt for assistance. ${ }^{241}$

Britain's "immediate needs are," telegraphed Churchill, "first of all, the loan of 40 or 50 of your older destroyers to bridge the gap between what we have now and the large new construction we have put in hand at the beginning of the war."242 Churchill warned that if Italy entered the war with its fleet of a hundred submarines, "we may be strained to breaking point."243 By May 25, the British chiefs of staff concluded, "without [significant American aid] we do not think we could continue the war with any chance of success." 244

${ }^{237}$ Ickes, Diary, note 17 above, at 200 (quoting the President). Accord Navy Secretary Frank Knox to Sumner Welles, 21 August 1940, State Department Records, National Archives, College Park, MD; Hague, note 234 above, at 15.

${ }^{238}$ See Conway, note 235 above, at 124; Hague, Destroyers, note 234 above, at 7-8.

${ }^{239}$ Admiral George Creasy to Philip Goodhart (n.d., ca. 1964), quoted in Goodhart, Fifty Ships, note 7 above, at 237. Accord, Gift Horse, 1952, Romulus Films ("displacement in gold").

${ }^{240}$ See notes 232-34 above and accompanying text.

${ }^{241}$ Telegram of 15 May 1940, quoted and discussed in Gilbert, Finest Hour, note 4 above, at 345-46.

${ }^{242} / \mathrm{bid}$. The new British destroyers would not be available until the end of the year. See note 230 above and accompanying text.

${ }^{243} \mathrm{lbid}$.

${ }^{244}$ Reynolds, Creation, note 7 above, at 98 (quoting chiefs of staff; emphasis original). 
The French also were clamoring for "destroyers ... of flush deck type."245

President Roosevelt almost immediately rejected Churchill's request for destroyers. ${ }^{246}$ In considerable detail, Roosevelt explained that he could not transfer the ships without Congressional authorization. Furthermore, the President frankly admitted, "it seems to me doubtful from the standpoint of our own defense requirements ... whether we could dispose even temporarily of these destroyers." 247 Finally, Roosevelt noted that even if the ships were transferred, it would take weeks, even months, before they could enter active service in the Royal Navy. 248

Less than a week later, Arthur Purvis, Britain's chief purchasing agent in the United States, again asked for destroyers and wrote in his notes, "Destroyers no. Quite firm." 249 Within the government, the Navy was the major source of opposition to any destroyer deal. Chief of Naval Operations Harold Stark adamantly opposed the idea. In private, the President explained, "On the Hill, [Stark] was asked the question about selling destroyers. 'Did they need them all?' And he answered yes." 250 Stark advised a fellow admiral, "I wish you would keep constantly in mind the possibility of a complete collapse of the Allies, including the loss of their fleets." ${ }^{251}$ On June 3, Secretary Morgenthau reiterated the President's firm opposition to giving

\footnotetext{
245 Monnet to Purvis, 17 May 1940, Morgenthau Diaries, note 23 above, Book 263, p. 172. See also Sumner Welles to George C. Marshall, 22 May 1940, ibid. Book 266, p. 25. The French request was denied shortly before June 3. Mr. Young to Secretary Morgenthau, memorandum, 3 June 1940, ibid. Book 268, p. 52.

${ }^{246}$ President Roosevelt to Winston S. Churchill, 17 May 1940, Churchill War Papers, note 1 above, 2:69-70. About a week later, the British asked the Canadians to send all of their destroyers across the Atlantic to help defend Britain. J.W. Pickersgill, The Mackenzie King Report (Chicago: Univ. Chicago Press, 1960) 1:116.

${ }^{247}$ Ibid., at 69

$248 \mathrm{lbid}$., at 69-70. Accord Adolph A. Berle, Navigating the Rapids, 1918-1971, ed. B. Berle and T. Jacobs (New York: Harcourt Brace Jovanovich, 1973), at 314 (diary entry of 15 May 1940).

${ }^{249}$ Arthur Purvis Notes, 23 May 1940, quoted in Goodhart, Fifty Ships, note 7 above, at 70 .

${ }^{250}$ Morgenthau, note to files, 5 June 1940, Morgenthau Diaries, note 23 above, Book 269, p. 58. Accord Notes of an interview with Secretary of State Hull, May 29, 1940 (Hull: "our navy people say we can't spare [destroyers]"), Raymond Clapper Papers, 80x 9, Folder 6, Library of Congress, Washington, DC.

${ }^{251}$ Harold Stark to J.O. Richardson, 22 May 1940, Harold Stark Papers, Naval Historical Center, Washington, DC.
} 
destroyers to the British, 252 but the day after Acting Attorney General Biddle rendered his opinion on surplus weaponry, ${ }^{253}$ Morgenthau saw a "ray of hope." $254 \mathrm{He}$ told the British that the President was contemplating "using the opinion of the [Acting] Attorney General as a basis for "transferring ten destroyers." 255 CNO Stark, however, remained opposed to releasing any of his destroyers. In late June, he saw the British position as "all but hopeless." 256 At the same time, the Chairman of the Senate Foreign Relations Committee was telling reporters, "It is no secret that Great Britain is totally unprepared for defense and that nothing the U.S. has to give can do more than delay the result." 257 If the British fell, the United States would be responsible for defending "two oceans," which would "require that we get every possible ship into effective operating commission without delay." 258

Churchill was "still pleading for destroyers" 259 on June 10 and that same day his worries about Italy entering the war came to pass. The threat of Italian submarines, however, was dwarfed by other disasters. France's mid-June surrender "left exposed the jugular of the British Empire." 260

The fall of France presented Britain with a serious dilemma. The Royal Navy had to guard against a cross-Channel invasion and at

252 "The President, himself, is firm on the destroyers. [He] has said no on that." Telephone transcript, 3 June 1940, Morgenthau Diaries, note 23 above, Book 268, p. 183

253 See notes 119-29 above and accompanying text.

254 Memorandum of telephone conversation, 5 June 1940, Morgenthau Diaries, note 23 above, Book 269, p. 58.

255 Ibid.

${ }^{256}$ Harold Stark to J.O. Richardson, 29 June 1940 (emphasis original), Harold Stark Papers, Naval Historical Ctr., Washington, DC.

257 Clapper Notebook, June 26, 1940, Raymond Clapper Papers, box 25, Library of Congress. Steven Early, the president's spokesman to the press, agreed. Ibid.

258 Harold Stark to J.O. Richardson, 14 June 1940, Harold Stark Papers, Naval Historical Center, Washington, DC.

${ }^{259}$ Ambassador Kennedy to Secretary of State, 10 June 1940 (relating conversation with Churchill), Foreign Relations, note 77 above, at 3:35-36. See also Destroyers (11 June 1940) Morgenthau Diaries, note 23 above, Book 271, p. 242. King George, himself, renewed the plea on June 26. King George VI to Franklin D. Roosevelt 26 June 1940, reprinted in John Wheeler-Bennett, King George VI, His Life and Reign (London: Macmillan, 1958), at 511.

260 Jackson, Final Draft, note 6 above, at 85 . 
the same time, had to protect shipping from submarine attacks. ${ }^{261}$ Destroyers were absolutely essential to both of these tasks, and the British simply did not have enough of them. By the beginning of the summer, their fleet had dwindled significantly. ${ }^{262}$ In late July, Churchill explained, "Destroyers are frightfully vulnerable to air bombing, and yet they must be held in the air bombing area to prevent seaborne invasion." 263 Obviously defending against an invasion was the highest priority bar none, and the Admiralty calculated that at a bare minimum, 36 to 40 destroyers had to be allocated to this task. ${ }^{264}$ This absolutely essential allocation left too few destroyers to protect shipping. ${ }^{265}$ Although the Germans had only a few Uboats operational in the summer of 1940, their assault upon the relatively unprotected British shipping was devastating. ${ }^{266}$ German $\mathrm{U}$-boat veterans later remembered this brief period as "the happy time."267

While the Roosevelt Administration was rejecting Churchill's pleas for destroyers, private citizens were banding together to support an aggressive policy of assistance to Britain. In May, William Allen White formed the Committee to Defend America by Aiding the Allies. ${ }^{268}$ The Committee placed special emphasis on influencing newspaper editors around the nation. ${ }^{269}$ White was a well-known Republican, and his Committee was quite bipartisan. ${ }^{270}$ By June, the

${ }^{261}$ See Stephen Wentworth Roskill, The War at Sea, 1939-1945 (London: He'r Majesty's Stationery Office, 1954), at 1:249-57.

262 For example, on June 17 , the British reported that they had only "133 destroyers in commission in home waters [but] only 68 are fit for 'service,' which is lowest level since the war started." Memorandum, 17 June 1940; Morgenthau Presidential Diary, Book 3; p. 588, FDR Library, Hyde Park, NY.

${ }^{263}$ Winston Churchill to President Roosevelt, 30 July 1940, Churchill War Papers, note 1 above, 2:593, 594.

${ }^{264}$ See ibid., at $249 \& 253$. The British anticipated that destroyers would be the primary weapon against a cross-channel invasion. Winston Churchill to Generals Ironside and Gill, 10 July 1940, Churchill War Papers, note 1 above, 2:496.

265 The British planned to use the old flush deckers "against U-boats on the western approaches and so keep the more modern and better gunned craft for the narrow seas against invasion." Winston Churchill to President Roosevelt, 30 July 1940, Churchill War Papers, note 1 above, 2:593-594.

${ }^{266}$ See Roskill, War at Sea, note 261 above, at 253, 348-52, \& 357.

267 See ibid., at 348.

${ }^{268}$ Langer \& Gleason, note 7 above, at $486-87$.

269 Ibid., at 710 .

270 /bid., at 755 . 
Committee had hundreds of local chapters spread across the nation, and eventually there were around six hundred chapters. ${ }^{271}$ That same summer, in early June, an informal group loosely associated with the White Committee began meeting at the Century Club in New York City. ${ }^{272}$ This Century Group, as it came to be known, was influential in bringing the Destroyers-for-Bases Deal to fruition. In particular, the Group played an important behind-the-scenes role in shaping government policy.

The Century Group first met in early June and naively resolved that the United States should immediately declare war on Germany. ${ }^{273}$ During the next two months, the Group worked out a more politically realistic plan that centered on trading destroyers to Britain in exchange for American base rights on British and Commonwealth territories in North America and the Caribbean and also a British agreement that in the event of a British defeat, the Royal Navy would not be given to Germany. ${ }^{274}$ More significantly, the Group began privately lobbying influential members of the national political establishment, including Wendell Willkie, who was the Republican Party's candidate for President, State Secretary Cordell Hull, War Secretary Stimson, Navy Secretary Knox, Interior Secretary Ickes, and American intelligence officers. ${ }^{275}$ The Group was well suited for this task because its members were predominantly northeastern Establishment WASPS with excellent ties to the media, government, and banking. ${ }^{276}$ Like the White Committee; the Century Group was bipartisan. ${ }^{277}$.The Group's members and White's Committee also mounted a nationwide newspaper campaign to support aid to Britain. ${ }^{278}$

\footnotetext{
271 lbid., at $567 \& 755$.

272 Francis Pickens Miller, Man From the Valley: Memoirs of a 20th Century Virginia (Chapel Hill: Univ. of North Carolina Press, 1971), chap. 9 (autobiography of Century Group's Secretary); Langer \& Gleason, note 7 above, at 506. For excellent monographic coverage of the Century Group, see Mark Chadwin, The Hawks of World War II (Chapel Hill: Univ. of North Carolina Press, 1968).

273 See Chadwin, Hawks, note 272 above, at 32-40.

274 Ibid., at ch. 4

275 Ibid., at 79-82; Ickes, Diary, note 17 above, at 270-71.

276 See Chadwin, Hawks, note 272 above, ch. III.

277 In a survey of 28 of the Group's most active participants, thirteen could be identified as Democrats and nine as Republicans. Ibid., at 66.

278 Ibid., at 77-106.
} 
Although the British government continued to press for destroyers, ${ }^{279}$ most people assumed that Jackson's torpedo-boat opinion precluded a transfer of destroyers to the British. ${ }^{280}$ In July and August, however, the political situation and the nature of the proposed destroyer Deal again changed. At the same time, three new legal opinions were written to distinguish the torpedo-boat opinion and to justify the sale of destroyers to Britain. Benjamin Cohen in the Interior Department wrote the first opinion. In twelve legal-sized pages, he provided an extensive cafeteria of ideas to support the Deal. A few weeks later, Dean Acheson (a Century Group member) and Cohen refined Cohen's initial memorandum and published it in the New York Times. Finally, in late August, Attorney General Jackson gave a formal opinion okaying the transfer of destroyers to Britain. Jackson based his opinion in significant part on Cohen's original memorandum and the Cohen/Acheson redraft.

\section{A. Benjamin Cohen's Opinion}

In real life, rendering an unwanted advisory opinion does not always conclude the advisory process. The opinion is not necessarily taken at face value. Instead, the client may seek a second opinion. Similarly, a senior attorney receiving an unwanted internal opinion from

${ }^{279}$ Aide-Memoire from British Embassy, 3 July 1940, Foreign Relations, note 77 above, at 3:42. On July 27, Churchill's private secretary noted in his diary, "Winston is now appealing eloquently to the President both directly and through Lothian for destroyers." Gilbert, Finest Hour, note 4 above, at 681 n. 1 (quoting diary). See also, ibid., at 688-89 (discussing Churchill's July 30 telegraphic plea).

${ }^{280}$ See Ickes Diary, note 17 above, at 271 (27 July 1940: “I told Ben [Cohen] very frankly, as Tom Corcoran already had, that in view of the Jackson [torpedo-boat] opinion the President could not now reverse himself."); William Allen White to Henry S. Coffin, July 23, 1940, William Allen White Papers, Box D14, Library of Congress, Washington, DC; Harold Ickes to Benjamin V. Cohen, July 23, 1940, Benjamin Cohen Papers, Box 8, Folder 2, Library of Congress, Washington, DC; Whitney Shepardson \& William Scroggs, The United States in World Affairs: An Account of American Foreign Relations, 1940 (New York: Harper \& Brothers, 1941), at 259; Chadwin, Hawks, note 270 above, at 87; Hall, North American Supply, note 60 above, at 142; see also Dean Acheson to Philip Goodhart, 15 Febrary 1960, Dean Acheson Papers, Box 38, Yale University; Arthur Krock, "The Parallels of AngloAmerican Interest," New York Times, 22 August 1940; Anne O'Hare McCormick, "Ship Sale to Britain is Made Urgent Issue by Nazi Drive," New York Times, 17 August 1940; "U.S. Destroyer Sale to Britain Reported Near," Chicago Daily Tribune, 17 August 1940; Editorial, New York Law Journal, 7 August 1940, quoted in New York Times, 7 August 1940. 
a junior attorney may refer the question to a second attorney for a de novo review. Moreover, the second attorney will almost always be a very capable professional recognized as having extraordinary legal skills. If the second attorney finds or creates an answer that the first attorney missed, the first attorney may suffer a loss of credibility and respect. This is one of the dynamics of the advisory process.

Jackson's torpedo-boat opinion did not really jeopardize his credibility or position of respect. First, he had an immense reservoir of credibility and respect with the President. Second, and perhaps more significant, given the Walsh and Vinson Amendments, ${ }^{281}$ Roosevelt probably liked having a legal opinion blocking the torpedo-boat transfer so that he could bow out of the deal gracefully. Others, however, were dissatisfied. In particular, others were upset by the implications of Jackson's opinion for the transfer of destroyers to the British. ${ }^{282}$ As is customary, they sought a second opinion from a gifted attorney.

In July, a leading member of the Century Group argued, "[i]f saving western civilization hinges on these [destroyers], then a way through the technicalities must be found." 283 Earlier that month, Joseph Alsop, an active member of the Century Group, and John Foster, First Secretary and legal adviser to the British Embassy, ${ }^{284}$ asked Benjamin Cohen to take an in-depth look at the transfer of vessels, especially destroyers, to the British. ${ }^{285}$ At about the same

\footnotetext{
${ }^{281}$ See note 190 above and accompanying text (Waish Amendment), notes 189 above \& 309 below and accompanying text (Vinson Amendment).

282 See note 278 above and accompanying text.

283 Francis Perkins Miller to Henry R. Luce, July 23, 1940, quoted in Allen Brinkley, The Publisher: Henry Luce and His American Century (New York; Alfred A. Knopf 2010), 262.

284 Foreign Office minutes, 24 February 1940, Public Records Office, London: Foreign Office files, 371, vol. 26224, pp 43-44. For biographical sketches of Foster, see www. rothschildfostertrust.com.

285 Chadwin, Hawks, note 272 above, at 89: Joseph Lash interview with Benjamin Cohen, 8 April 1974, Joseph P. Lash Papers, Box 59, FDR Library, Hyde Park, NY. A little over a month earlier, Cohen had drafted legislation, in the form of a joint resolution, for Senator Claude Pepper of Florida to authorize the United States, itself to sell airplanes to the Allies. See Kimball, Unsordid Act, note 127 above, at 46-47 Key Pittman to Cordell Hull, 21 May 1940 (text of joint resolution), Cordell Hull Papers, Library of Congress, Washington, DC; The State Department, through Legal Advisor Hackworth, opposed the legislation as "contrary to our position as a neutral
} 
time, Justice Felix Frankfurter also privately suggested to Cohen that he undertake this task. ${ }^{286}$ Cohen was an ideal candidate for this task because he was one of the most respected and influential attorneys in government. ${ }^{287}$ The British viewed Cohen as "a left-wing New Dealer, very friendly to the British cause, [and] very close to the President." ${ }^{288}$ Cohen clearly favored a vigorous policy of aiding Great Britain. ${ }^{289}$

Cohen took about a week to write his memorandum. ${ }^{290}$ As is to be expected, his explorations of the issue took him down a few cul de sacs. ${ }^{291}$ Moreover, as is customary, important and controversial legal opinions are almost never the work of one person. No matter how capable a lawyer may be, input from others is essential. One attorney may become lost in the details of the analysis, may think that some points are obvious when others would disagree, or may simply miss a crucial point. Perhaps Mr. Foster, who along with Alsop, had urged Cohen to undertake the task, lent a hand on international law issues. ${ }^{292}$ In addition, Cohen may have had a copy of Townsend's torpedo-boat memorandum. ${ }^{293}$ Because Cohen undertook the task at Justice Frankfurter's suggestion, Cohen probably consulted with Frankfurter. In later years, he said, "I was working

under international law." Green Hackworth to the Secretary [Hull], 21 May 1940, Cordell Hull Papers, Library of Congress, Washington, DC. Senator Pepper's proposal died in committee.

${ }^{286}$ Chadwin, Hawks, note 272 above, at 97; Miller, Man From the Valley, note 272 above, at 101.

287 See notes 15-18 above and accompanying text.

288 Viscount Halifax to Foreign Office, 20 February 1941, Public Records Office, London: Foreign Office files, 371, vol. 26224, p. 43.

${ }^{289}$ The same month that he wrote his memorandum, he wrote a friend, "I am shocked by the apparent apathy and unconcern among our people regarding the fate of England and our failure to appreciate the magnitude of the task of saving democracy if England goes down." Benjamin V. Cohen to Charles C. Burlingham, 24 July 1940, Charles C. Burlingham Papers, Harvard Law Library. Burlingham was an extremely influential and well-connected attorney in New York City.

290 On July 12, he telephoned his friend Oscar Cox, an attorney at the Treasury, and told him he planned "to make a complete resurvey of the legal situation in connection with the sale of naval vessels to the British." Oscar Cox Diary, 12 July 1940, Oscar Cox Papers, FDR Library, Hyde Park, NY

291 See, e.g., note 313 below.

292 Before the war, Foster lectured on private international law at Oxford. "Sir John Foster Dead," New York Times, 3 February 1982.

${ }^{293}$ See notes 192-204 above and accompanying text 
with Felix" on the issue of transferring destroyers to the British. ${ }^{294}$ We know that Cohen gave a preliminary draft to a friend at Treasury to review and provide comments. ${ }^{295}$ After incorporating some of his friend's comments, he sent his final memorandum to the President on July 19,296 and three days later, he sent a copy to Attorney General Jackson. ${ }^{297}$

Giving legal advice in government is not always a simple exercise in legal analysis. If the contemplated action has significant political dimensions, the advisory process necessarily has political facets as well. ${ }^{298}$ Cohen wrote the memorandum for President Roosevelt, and his clear objective was to assure the President that the government could lawfully transfer the destroyers to Britain. Cohen also wrote the memorandum with a second person specifically in mind. He knew that he had to convince the Attorney General that the destroyer deal would be lawful notwithstanding the torpedo-boat opinion. 299

Cohen began his memorandum with a subtle, but important, point. Assessing the legality of sending destroyers to Great Britain was not a simple exercise in statutory construction in which the

294 Joseph Lash's interview with Benjamin Cohen, 8 April 1974, Joseph P. Lash Papers, FDR Library, Hyde Park, NY. This portion of the interview conflates Cohen's initial memorandum, the Cohen/Acheson rewrite, and Jackson's opinion. Cohen was intimately involved in writing all three opinions.

295 See Oscar Cox Diary, 12, 18, \& 22 July 1940, Oscar Cox Papers, FDR Library, Hyde Park, NY; Oscar Cox to Benjamin Cohen, 18 July 1940 (providing comments), Benjamin Cohen Papers, Library of Congress, Washington, DC.

296 Undated memorandum: "Sending Effective Material Aid to Great Britain with Particular References to the Sending of Destroyers," attached to Benjamin V. Cohen to the President, 19 July 1940, President's Secretary's Files, FDR Library, Hyde Park NY.

${ }^{297}$ Memorandum: "Sending Effective Material Aid to Great Britain with Particular References to the Sending of Destroyers," (Confidential Draft of 19 July 1940), attached to Benjamin V. Cohen to Robert H. Jackson, 22 July 1940, Robert H. Jackson Papers, Library of Congress, Washington, DC.

${ }^{298}$ Similarly, in private practice a legal opinion must take into account the matter's business or social context, and the client's extralegal desires and constraints.

${ }^{299}$ A few weeks later, Cohen and Dean Acheson redrafted Cohen's memorandum and published the redraft in the New York Times. See notes $380-430$ below and accompanying text. Although the Times letter attracted much favorable public, Dean Acheson later explained, "What we were after was the favorable attention of two men in particular: [Jackson and Roosevelt]." Acheson, Morning, note 20 above, at 223. 
proposal simply would be measured against the apparent meaning of the statute. Nor was the proposal to aid Britain a matter of proBritish altruism. Instead, "our own national defense" ${ }^{300}$ was at stake. Therefore, Cohen argued, "It cannot lightly be assumed that statutes designed to safeguard our national defense were intended to block action dictated by a realistic appreciation of the interests of our national self defense." 301

Attorneys routinely invoke vague concepts like "national defense" or "public policy." These generalities, however, have little or no value in legal analysis unless the attorney explains exactly how national defense is implicated or what exactly the public policy is. Cohen avoided vague generalities. He explained the precise consequences of the destroyer transfer for America's self defense. By strengthening Britain, he believed, "the danger of German aggression being directed against us in the immediate future is enormously reduced." 302 Moreover, even if Germany ultimately defeated the British, the transfer of the destroyers at least would delay the German victory. The value of delay could not be dismissed because "the longer [Britain] holds out, the more time we will have to strengthen our defenses and the more time it will take Germany to repair and rehabilitate her armaments before she will be able to launch an attack on the Western Hemisphere." ${ }^{303}$ Cohen's concern about a German attack on the United States was not a lawyer's fantasy created to fit the needs of the occasion. A few weeks earlier, the U.S. Naval Attaché in London firmly stated, "In my view safety of United States would be definitely in jeopardy should British Empire fall, and would expect Italo-German combination to move swiftly in South America and Caribbean areas." ${ }^{304}$

\footnotetext{
${ }^{300}$ Cohen Memorandum, note 296 above, at 1

301 /bid.

302 Ibid.

303 /bid.

${ }^{304}$ Watson, Chief of Staff, note 84 above, at 107, quoting Captain Alan Kirk. Accord, Admiral J.O. Richardson to CNO Harold Stark, 13 May 1940, Harold Stark Papers, Naval Historical Center; Robert Dallek, Franklin D. Roosevelt and American Foreign Policy, 1932-1945, (New York, Oxford Univ. Press, 1979), at 233-36. Captain Kirk was also concerned about the "safety of [the Panama] Canal." Although Captain Kirk was later promoted admiral, regrettably, he never commanded the aircraft carrier USS Enterprise.
} 
Having established the need to construe the relevant statutes to further national defense, Cohen turned to the specific legal issues. He took a comprehensive lawyerly approach. First, he considered whether Congress had granted the President authority to dispose of the destroyers. Then he considered whether specific legislation and international law revoked or limited the President's authority. This organization makes sense, but as a practical matter, it seriously weakened Cohen's memorandum. Cohen's least persuasive arguments dealt with the President's basic authority to dispose of the ships. His analyses on this point were at best intricate and at worst preposterous. By leading off with his weakest analyses, he damaged the general credibility of his memorandum.

An obscure but fundamental principle of constitutional law lurked in the shadows of the destroyers deal. ${ }^{305}$ The Constitution provides, "The Congress shall have power to dispose of and make all needful Rules and Regulations respecting the Territory or other Property belonging to the United States." ${ }^{306}$ Pursuant to this clause, the principle was well established in 1940 that the President lacked authority to transfer federal property without an express or implied delegation from Congress. ${ }^{307}$ About ten years earlier, the Attorney General had advised the President that "the directions of Congress are controlling with respect to the [transfer of federal property]."308 Just three days before Cohen completed his memorandum, Congress enacted the Vinson Amendment providing that, "No vessel, ship, or boat ... now in the United States Navy ... shall be disposed of by sale or otherwise . . except as now provided by law." 309

\footnotetext{
305 See H. Jefferson Powell, The Constitution and the Attorneys General (Durham: Carolina Academic Press, 1999), 315.

306 U.S. Constitution, art. 4, sec. 3, cl. 2.

${ }^{307}$ Most of the cases involved real property, but the property clause clearly extended to the sale of personal property as well. Ashwander v. Tennessee Valley Authority, 297 U.S. 288 (1936) (electricity); United States v. City and County of S.F., 310 U.S. 16 (1940) (hydroelectric power).

30836 Op. Att'y Gen. 75 (1929) (Att'y Gen. Mitchell). Accord Edward Corwin, "Executive Authority Held Exceeded in Destroyer Deal," New York Times, 13 Oct 1940 (letter). See also 28 Op. Atty Gen. 143 (1910) (Att'y Gen. Wickersham).

${ }^{309}$ Act of July $19,1940,76$ th Cong., $3 d$ sess., ch. $644, \S 7,54$ Stat. 780 , codified at 34 U.S.C. $\$ 493$ a (1940 codification).
} 
Given this clear language, Cohen had to identify an act of Congress authorizing the destroyers' disposal. ${ }^{310} \mathrm{He}$ began by suggesting that the ships could be sold under World War I legislation authorizing the Navy Secretary to sell "auxiliary ships of the Navy classified as colliers, transports, tenders, supply ships, special types, and hospital ships." ${ }^{\prime 311}$ The statute further provided that the ships had to be over eighteen years old and that the Secretary must determine that the ships were "unsuited to the present needs of the Navy."312

As the examples of auxiliary ships provided in the statute suggest, this type of ship is not a combat ship. Instead, their role is to support combat ships. ${ }^{313}$ The Navy, however, was then using many of the destroyers in question as combat vessels. Some of the destroyers eventually transferred sailed directly from active duty on the Neutrality Patro ${ }^{314}$ to Canada. ${ }^{315}$ The British urgently needed the destroyers for combat. Because a destroyer by any other name is

${ }^{310}$ In selecting the statutes that might authorize transfer of the destroyers, Cohen probably was influenced by the Vinson Amendment's Senate Report, dated two weeks earlier, which specified only two statutes that could be used to dispose of vessels. See S. Rep. 76-1946, 76th Cong. 3rd sess., at 7-8 (July 8, 1940), citing 34 U.S.C. $\S \S 491-92$ \& 493 (1940 codification).

31134 U.S.C. $\$ 493$ (1940 codification).

312 lbid.

313 Cohen researched the definition of auxiliary vessel and could not come up with a more precise meaning. See Cohen, untitled two-page note (n.d.), Benjamin Cohen Papers, Library of Congress, Washington, DC. The Second London Treaty defined the term as "vessels ... not specifically built as fighting ships." Ibid. The then current Webster's dictionary defined the term as "a vessel auxiliary to the fighting vessels." Ibid. He concluded that the term "may probably be said to include vessels which do not function as combatants, even though they bear armor and guns." Ibid.

Some of the old destroyers had actually been converted to auxiliary vessels like seaplane tenders and transports. Memorandum for Senator James F. Byrnes, 7 August 1940, Joseph Alsop Papers, Library of Congress, Washington, DC. See also "Destroyer is Now Seaplane Tender," New York Times, July 2, 1940. The British, however, wanted unconverted destroyers that they could use as destroyers.

${ }^{314}$ When the war began, the United States and other American countries declared that belligerent ships must keep a distance (with exceptions for Canada and European colonies) of 300 miles from the Americas. The United States Navy enforced the declaration with a neutrality patrol. See Reynolds, Creation, note 7 above, at 64-65.

315 Joseph H. Boener, "From Battleships to Bridges: The Naval Career of Commodore Schulyer Franklin Heim" (master's thesis, Marine Corps Univ., 2001), at 51-53; Reminiscences of Vice Admiral Roland N. Smoot, U.S. Navy (Retired), at 6062 (1972) (oral history: Captain of U.S.S. Aulick), Naval Historical Center, DC. 
still a destroyer, Cohen's suggestion that the destroyers were not combat vessels verges on the preposterous. ${ }^{316}$ Finally, they clearly were not "unsuited to the present needs of the Navy." ${ }^{317}$ Cohen knew that his auxiliary vessel analysis was a stretch. Moreover, his friend at Treasury had told him that the Navy never used the auxiliary ship statute. ${ }^{318}$ Instead, the Navy always used legislation authorizing the sale of vessels struck from the Navy Register. ${ }^{319}$

As a backup analysis, Cohen turned to this law. Under it, the Navy Secretary first would exercise his authority to strike the ships from the Navy Register, ${ }^{320}$ and then he would sell them. ${ }^{321}$ This path made some legal sense, but like the auxiliary-vessel argument, it foundered on the facts. In order to strike vessels from the Navy Register, the Navy had to determine that the "vessels are unfit for further service." ${ }^{\prime 22}$ Again, given the fact that the ships were on active service and that the British urgently needed them for active combat service, the ships could not possibly be condemned as "unfit for further service." A Treasury attorney bluntly commented, "to use the device of striking from the register as 'unfit for further service' shocks my integrity when it is considered that the vessels are intended to be used for active naval service." ${ }^{223}$ Just a month earlier, Chief of Naval

316 See Moss, Nineteen Weeks, note 7 above, at 258 ("Jesuitical logic"). Although the destroyers clearly were not auxiliary vessels, Cohen suggested an end run around the statute. Another act empowered the President "to modify, as the needs of the service may require, a classification of vessels of the Navy." 34 U.S.C. $\$ 451$ (1940 codification). Prior to 1940 , some of the flush deckers had been converted to fast minelayers, fast minesweepers, light seaplane tenders, and fast transports. Conway, note 235 above, at 124. The British, however, needed destroyers for destroyer duty. Therefore, these converted ships would not have fit Britain's needs.

${ }^{317}$ See note 312 above and accompanying text.

318 Oscar Cox Diary, 12 July 1940 (relating advice from Admiral Ray Spear), Oscar Cox Papers, FDR Library, Hyde Park, NY.

31934 U.S.C. $\$ \$ 491$ \& 492 (1940 codification).

${ }^{320}$ Act of Aug. 5, 1882, 47th Cong. 1st sess., ch. 391, §2, 22 Stat. 296, 34 U.S.C. $\S 491$ (1940 codification).

${ }^{321}$ Act of March 3, 1883, 47th Cong. 2nd sess., ch. 141, $\S 5,22$ Stat. 599, 34 U.S.C. $\S 492$ (1940 codification).

32234 U.S.C. $\$ 491$ (1940 codification).

323 [Dudley] Easby's Comments, 12 August 1940, Oscar Cox Papers, FDR Library, Hyde Park, NY. Easby continued, "A Secretary who made such a finding might be embarrassed when called upon to explain why the ships were unfit for us, but fit for the Royal Navy." Ibid. 
Operations Stark had testified to Congress that the Navy needed to overhaul more of the old four-stackers because they "will be in general service just as the rest of the fleet is in general service, ready in case of need." ${ }^{224}$ In view of these virtually insurmountable difficulties, Cohen advanced this argument as a secondary or backup position. ${ }^{325}$

Finally, Cohen suggested an additional secondary or backup analysis. ${ }^{326}$ The Navy had recently transferred 50 Helldiver dive bombers to the Army that were then sold to Britain under the War Secretary's authority to dispose of surplus Army property. ${ }^{327}$ Why not do the same with the destroyers? An act from the end of World War I allowed the Navy to transfer "military stores, supplies and equipment of every character" 328 to the Army and once in the Army's hands, the Army could use its recently enacted authority "for the exchange of deteriorated, unserviceable, obsolescent, or surplus military equipment ... for other military equipment, munitions, and supplies." 329

If these two statutes are viewed in isolation, they are arguably written in sufficiently broad terms to encompass the destroyers. The interservice transfer authority extended to "equipment of every character," and in a sense the destroyers were clearly "obsolescent"

\footnotetext{
${ }^{324}$ Senate Appropriations Subcommittee, Supplemental Hearing: Navy Department Appropriations Bill for 1941, 77th Cong., 3rd sess., 21 \& 22 May 1940, p. 8 . When a Senator asked, "are these old destroyers useful as combat vessels?" Admiral Stark responded "They would be used for antisubmarine work; they would be used for scouting; they might be used for combat; they would be used for escort work. They could be used whenever we need them." Ibid. See also Shogan, Hard Bargain, note 7 above, at 217.

325 The argument appears as a footnote in a near final draft. Confidential Draft, 19 July 1940, Benjamin Cohen Papers, Library of Congress, Washington, DC). Cohen moved many of his footnotes to the text in the memorandum that he gave the president.

${ }^{326}$ Like his analysis of Sections $491 \& 492$, Cohen placed this third analysis in a footnote to his near final draft. Confidential Draft, at $3 n^{*}$, ibid.

${ }^{327}$ See notes 108 \& 181-85 above and accompanying text.

${ }^{328}$ Act of July 11, 1919, 66th Cong., 1st sess., ch. 9, 41 Stat. 131, 132, 10 U.S.C. $\$ 1274$ (1940 codification).

${ }^{329}$ An Act to expedite the strengthening of the national defense, Pub.L. 76-703, 76th cong., 3d sess., ch. 508, $\$ 1$ (a)(3), 54 Stat. 712. Acting Attorney General Biddle's opinion (see notes 119-34 above and accompanying text) could not be used because the destroyers were not in the War Department's possession before 1919. They were in the possession of the Navy Department.
} 
as required by the recently enacted exchange authority. Although this scheme had already been used to transfer obsolescent dive bombers, the destroyers were significantly different from the bombers. The previously transferred airplanes were old biplanes and not to be confused with the modern Douglas Dauntless Helldivers that struck the decisive blow two years later at the Battle of Midway. ${ }^{330}$ The biplanes were in the process of being phased out of use while the Navy had a continuing need for the destroyers. In early June, President Roosevelt had denied a French request for some of these old destroyers and explained, "Our old destroyers cannot be sold as obsolete as is proven by fact. All of them are now in commission and in use or are in process of being commissioned for actual use." ${ }^{331}$ A month later, the president continued in this same vein, commenting that "it would be difficult to [certify the destroyers as "useless"] in view of the fact that we were reconditioning more than one hundred of them for use for our own defense purposes." 332 In August, CNO Stark refused to strike the destroyers from the Navy Register. ${ }^{333}$

Having advanced three weak arguments that existing statutes authorized the destroyers' transfer, Cohen then took up the recently enacted Walsh Amendment. The Amendment's wording focused upon the ships to be sold and seemed to frame the issue in terms of whether the destroyers, themselves, were "essential" to national defense. Cohen, however, had a brilliant insight. Rather than focusing on the value of the ships, he focused on the value of the deal. He urged that the Walsh Amendment would not bar the destroyer's release, "if the Secretary of Navy finds, as there is good reason for him to find, that the present needs of the Navy and the present requirements of national defense would be best served by their release." 334 In other words, the amendment should not be interpreted to prohibit a release of ships when the net effect is to enhance national defense.

${ }^{330}$ See note 1819 above.

${ }^{331}$ F.D.R. to Undersecretary of State [Welles], 1 June 1940, FDR Library, President's Secretary's Files.

332 Ickes, Diary, note 17 above, at 233.

${ }^{333}$ See notes $476-83$ below and accompanying text.

334 Cohen memorandum, note 296 above, at 3. 
The memorandum would have been marginally better if Cohen had expressly explained or alluded to the net effect of releasing the destroyers to the British. The negative consequence of the release was clear. The Navy would lose 50 destroyers capable of patrolling the high seas. On the positive side, the country would gain the purchase price of the ships, but this slight fiscal gain would not enhance national defense to any appreciable degree. ${ }^{335}$ Presumably, Cohen had in mind the national defense advantages that he had outlined on the first page of the memorandum. The released destroyers would immediately be placed in active service against Germany and thereby prevent or significantly delay a feared German attack on the United States or United States interests in the Western Hemisphere.

Whether the intangible gain of forestalling a German attack was greater than the tangible loss of fifty destroyers is a very difficult question. The answer clearly would be informed by a complex array of military and foreign policy facts and judgments, and the answer ultimately would turn upon subjective judgment, even intuition. Because the Executive Branch plays a significant role in shaping foreign and national defense policy and has a more complete knowledge of the relevant facts and factors, Cohen probably believed that answering the question should be left to the Executive. As a general proposition, he surely was correct. Indeed, Jackson used a significant variation of this analysis a month later to justify the destroyers' transfer.

The problem with Cohen's analysis was that Congress did not enact the Walsh Amendment in a theoretical vacuum. The Congress collectively knew, or believed, that the Executive Branch was contemplating selling destroyers to the British through American intermediaries. ${ }^{336}$ Walsh was in a "towering rage;" and his committee was "in lather." Some very capable people believed that the feared German assault on the Western Hemisphere was unlikely to happen. ${ }^{337}$ Moreover, there was a possibility that the Germans might

${ }^{335}$ Jackson, Final Draft, note 6 above, at 97; 86 Cong. Rec. 10404 (15 August 1940) (Sen. Tydings).

${ }^{336}$ Chesley Manley, "Roosevelt War Policy Arouses Growing Storm," New York Times, 22 June 1940 (Sen. Walsh notes ongoing "negotiations for the release of destroyers). Cf. "British Would Buy Destroyers Here," New York Times, 12 June 1940.

${ }^{337}$ See, e.g., Manley Hudson to Charles Culp Burlingham, 12 November 1940, Hudson Papers, Harvard Law Library, Harvard University, in which Hudson, who 
defeat Britain, gain control of the destroyers, and turn them against the United States. ${ }^{338}$ The simple fact was that the Walsh Amendment, which was enacted just a few weeks earlier, clearly was intended to forbid a simple sale of the destroyers to the British. When Cohen wrote his memorandum, nothing had changed.

Cohen also addressed the difficult issues of international law and the Espionage Act. Although he noted a cute argument that the Hague Convention's rules might be totally inapplicable, ${ }^{339}$ he did not rely upon this clever technicality. The bulk of his analysis assumed that Hague and The Three Rules of Washington ${ }^{340}$ were fully applicable.

Cohen began with the assumption that the Finland model of intermediaries would be used to accomplish the transfer and therefore concentrated upon international law principles forbidding the

was a judge on the Permanent Court of International Justice, noted, "I have not been able to see the great danger of an invasion of the United States by the Germans."

${ }^{338}$ See notes $45-46$ above and accompanying text.

${ }^{339}$ Confidential Draft, note 297 above, at 6, n. *. The Hague Convention. XIII, art. 28 provided that the Convention would only apply when "all the belligerents are parties to the Convention" 36 Stat., at 2433. Cohen noted that Poland never became a party to the Convention. Confidential Draft, note 297 above, at $6 \mathrm{n}$. *. The better examples were Great Britain and Italy who participated in the negotiations, but never ratified the Convention. See Deak \& Jessup, A Collection of Neutrality Laws, Regulations and Treaties, (Concord NH: Rumford, 1939), 2:1376. Cohen borrowed this slight of hand from a friend in the Treasury Department. See Oscar Cox to Benjamin Cohen, 18 July 1940, Benjamin Cohen Papers, Library of Congress, Washington, DC. Cox was riding his hobby horse as early as June 25. Oscar Cox Diary, 25 June 1940, Oscar Cox Papers, FDR Library, Hyde Park, NY. The basic problem with this argument was that many-perhaps most-people viewed the Hague Convention's neutrality rules as restating limitations that in any event existed in international law as general principles. See note 53 above and accompanying text. Nevertheless, the argument should not be entirely discounted. The State Department's Legal Adviser presented the non-signatory argument to a high school history instructor in September. Green H. Hackworth to F.H. Feeney, 18 September 1940, State Department Records, National Archives, College Park, MD. When Hackworth drafted a statement for Secretary Hull at about the same time, he advanced this argument as one of three independent justifications under international law for the Destroyer Deal. Green Hackworth, Draft from Mr. Hackworth of statements regarding Anglo-American defense negotiations, (n.d., ca. fall 1940) Cordell Hull Papers, Library of Congress, DC. Cohen did the same in an August 23 set of talking points that he prepared for the President. Benjamin V. Cohen to Marguerite Le Hand, 23 August 1940 (with attached talking points), Benjamin Cohen Papers, Library of Congress, DC.

${ }^{340}$ See notes 61-68 above and accompanying text. 
private sale of weaponry to belligerents. Using a lengthy quotation from Hersh Lauterpacht, he established the fundamental principle that private actors in a neutral country are free to sell all kinds of contraband, including warships, to belligerents. ${ }^{341} \mathrm{He}$ then directly confronted The Three Rules of Washington and argued that the Three Rules allowed the sale of warships as long as the warships did not mount combat operations upon their initial voyage from the neutral port.

Cohen used common-law reasoning to limit the Three Rules to the facts of the original Alabama dispute ${ }^{342}$ that engendered the rules. During the Civil War, the Alabama sailed from England fully prepared, except for guns and ammunition, to cruise against United States shipping. At the Azores, the Confederate raider took on her necessary armament from other ships that also had sailed from England. Under this analysis, the purpose of the Three Rules was to forbid belligerents from mounting naval operations from neutral ports. ${ }^{343}$ The mere sailing of warships was permissible as long as they were not used to cruise against belligerents on their initial voyage.

In other words, Cohen viewed the Three Rules as forbidding the sale of warships only when the ships would sail on combat missions directly from a neutral port. In support of this distinction, he quoted an 1822 Supreme Court opinion in which Justice Story wrote that Americans could equip a vessel for combat and sail it from an American port with the intention of selling the vessel in a foreign port to a belligerent. ${ }^{344}$

\footnotetext{
${ }^{341}$ Cohen memorandum, note 296 above, at 4-5, quoting Lauterpacht's Oppenheim, note 62 above, $\$ 334$.

${ }^{342}$ Cohen probably based his description of the Alabama case on Lauterpacht's treatment of that case. See Lauterpacht's Oppenheim, note 62 above, $§ 335$.

${ }^{343}$ Cohen memorandum, note 296 above, at 4-7.

${ }^{344}$ La Santissima Trinidad, 20 U.S. (7 Wheat.) 283 (1822). Lauterpacht cited this case with approval but noted that the technicality of delaying the sale until the vessel reached a foreign port was "hairsplitting." Lauterpacht's Oppenheim, note 62 above, at 714. Many-probably most-international lawyers rejected La Santissima Trinidad as no longer the law. See e.g., Briggs, "Neglected Aspects," note 53 above, at 579-80; Professor Phillip Jessup to Charles C. Burlingham, 12 August 1940, Burlingham Papers, Harvard Law Library, Harvard University. Quincy Wright, who fully supported giving the British destroyers, agreed. See Quincy Wright to Charles Burlingham, 21 August 1940, Dean Acheson Papers, Box 6, Yale University; Charles C. Burlingham to Felix Frankfurter, 28 August 1940, Felix Frankfurter Papers, Box 34, Library of Congress, Washington, DC.
} 
Having established that the destroyer deal could be properly structured to comply with the international law against fitting out warships in neutral ports, Cohen turned to the old Neutrality Act and the more recent Espionage Act. His argument was simple and direct. Because these acts were passed to fulfill the United States' international law obligations, they need not be construed more broadly than those international obligations. ${ }^{345}$

He concluded that the old Neutrality Act was limited to situations in which warships would sail from United States and immediately engage in hostilities. Therefore, the old Act would not apply to a transfer in which ships would sail peacefully from an American port to a belligerent port and not engage in hostilities until manned in the belligerent port. ${ }^{346}$

The Espionage Act was a more difficult nut to crack because it used language that on its face, seemed to be more restrictive than the international law principle against mounting military operations from neutral ports. The statute is prolix, but when its surplusage is pared away, it contained four elements in the following order:

A. "During a war in which the United States is a neutral nation ..."

B. "it shall be unlawful to send out of the United States ..."

C. "any vessel built ... as a vessel of war..."

D. "with any intent that such vessel shall be delivered to a belligerent nation. . . ."347

Cohen read the statute as presenting a common form of ambiguity. Did the intent requirement in part $D$ modify the "built" requirement in part $C$ or the "send out" requirement in part B? Based upon legislative history and international law, he concluded that the intent requirement modified the "built" requirement. Because the destroyers were not originally "built" with an "intent" that they would be "delivered to a belligerent nation," he concluded that the statute was inapplicable to the sale of the ships to the British.

\footnotetext{
${ }^{345}$ Of course, as a matter of domestic policy, the United States might adopt broader measures that were mandated by international law. Absent clear evidence to the contrary, however, the act surely should not be construed to harm national security. See notes $300-01$ above and accompanying text.

${ }^{346}$ He supported this conclusion with The Santissima Trinidad and Lauterpacht's Oppenheim, discussed in note 344 above.

${ }^{347}$ For the full wording of the Act, see note 524 above.
} 
Cohen's interpretation of the Espionage Act was especially significant because it enabled him to distinguish Jackson's torpedo-boat opinion. Under the facts of the torpedo-boat deal, the boats were to be "built, armed, or equipped" by Elco under an agreement that they would "be delivered to a belligerent nation." As Assistant Treasury Secretary Gaston had commented, "There is a perfect record made here for the prosecution of the Electric Boat Company." ${ }^{348}$

Cohen wrote most of his memorandum on the assumption that the government would transfer the destroyers using the Finland, or intermediary, model. Before concluding his analysis, however, he suggested the possibility of a direct transfer to the British. Perhaps Joseph Alsop from the Century Group suggested this alternative, or perhaps it just occurred to Cohen as an afterthought. Cohen did not fully elaborate his thoughts on a direct transfer, but he clearly understood that a direct transfer would moot the problems posed by the old Neutrality Act and the Espionage Act. On their face, the two Acts were directed at the actions of individuals rather than the government itself. Moreover, Cohen knew that there was a well-established principle of statutory construction that legislation does not limit government action unless the legislation is expressly applicable to the government. ${ }^{349}$

Although a direct transfer would dispose of the old Neutrality Act and the Espionage Act, a direct transfer would clearly violate the terms of the Hague Convention. Cohen neither quoted nor cited the Hague Convention's prohibition of direct or indirect assistance to belligerents, but he did offer a counter argument. ${ }^{350} \mathrm{He}$ believed that Germany's misconduct excused the United States from complying with the Convention. First, Germany had violated the Kellogg-Briand Peace Pact in which Germany, the United States, and others had renounced war. In addition, Germany had violated the neutrality of countries like the Netherlands and Belgium. Cohen

\footnotetext{
${ }^{348}$ Conference transcript, 20 June 1940, Morgenthau Diaries, note 23 above, Book 274, p. 292.

${ }^{349}$ Cohen Memorandum, note 296 above, at 10-12 $\mathrm{n}^{*}$, citing Dollar Savings Bank v. United States, 86 U.S. 227, 239 (1873); United States v. Herron, 87 U.S. 251 (1874); California Iron Yards Company v. Commissioner of Internal Revenue, $47 \mathrm{~F}$ 2d 514 (9th Cir. 1931). Accord, Hancock v. Train, 426 U.S. 167, 179 (1976).

${ }^{350}$ Cohen Memorandum, note 296 above, at 10-11 $n$ *. See also Benjamin V. Cohen to Charles Culp Burlingham, 15 October 1940 (restating international law analysis), Charles C. Burlingham Papers, Harvard Law School.
} 
argued that this misconduct authorized other neutral countries like the United States to engage in reprisals against Germany.

Cohen sent his memorandum to President Roosevelt on July $19,{ }^{351}$ but the President almost immediately wrote Frank Knox, the new Navy Secretary, that he doubted that Cohen's argument "would stand up." 352 He believed that the Walsh Amendment was "intended to be a complete prohibition of sale." 353 The President also "fear[ed] Congress is in no mood at the present time to allow any form of sale." 354 Other politically astute New Dealers told Cohen "that in view of the Jackson [torpedo-boat] opinion the President could not now reverse himself." 355

Although the president initially rejected of Cohen's analysis, the political and national security calculus regarding support for Britain continued to change. Throughout the summer, one of the Roosevelt Administration's central concerns was the nagging fear that Germany might knock Britain out of the war. In Jackson's words: "The axis seemed, in that summer, likely to extinguish every vestige of effective resistance in Europe and to leave us trying to exist in the world alone against it." 356 If this catastrophe were to come to pass despite a transfer of destroyers, the United States would face Germany with a significantly reduced fleet. Even worse if Germany were to combine its fleet with the French, British, and Italian fleets, we would be woefully outgunned. ${ }^{357}$ These fears were somewhat assuaged in early July when the Royal Navy attacked and destroyed a significant part of the French fleet. ${ }^{358}$ This drastic action against a

${ }^{351}$ Benjamin V. Cohen to the President, 19 July 1940, President's Secretary's Files FDR Library, Hyde Park, NY.

352 President Roosevelt to Frank Knox, 22 July 1940, in F.D.R., His Personal Letters, note 136 above 2:1048-49.

353 I bid.

354 Ibid.

355 Ickes, Diary, note 17 above, at 217 (Harold Ickes and Thomas Corcoran).

356 Jackson, Draft 1-19, note 6 above, at 7. Accord, Jackson, Draft 1-20, note 6 above, at 4 .

357 See David Reynolds, Lord Lothian and Anglo-American Relations, 1939-1940 (Philadelphia: American Philosophical Society, 1983), at 19-25. At times, the British exacerbated these fears by suggesting that a German victory might result in German possession of the Royal Navy. See ibid., at 114-15 \& 118-20; Leutze, Bargaining, note 7 above, at 75, 78, 85, \& 88 .

${ }^{358}$ See Martin, Finest Hour, note 4 above, ch. 31. 
recent ally convinced Roosevelt that the British were determined to continue fighting at all costs..$^{359}$

On July 30, British Ambassador Lothian cabled Churchill that "Strong pressure is being brought on the President to reconsider possibility of supplying us with destroyers." 360 White's Committee to Defend America ${ }^{361}$ had endorsed selling the destroyers through a private intermediary and at the end of the month ran six-column advertisements in major newspapers urging the sale. ${ }^{362}$ At a July 25 meeting, the Century Group came up with the idea of exchanging the destroyers for bases. ${ }^{363}$ Henry Luce, the Republican publisher of Time, Life, and Fortune magazines, reported on discussions that he had had with Hull and with Roosevelt. ${ }^{364}$ In response to Luce's urging a transfer of destroyers, Hull had raised legal and political concerns. The President's main concern was his re-election in the fall. At the July 25 meeting, the Group discussed Britain's need for destroyers, and Luce suggested a new approach to the problem: "these destroyers should be offered to Britain in exchange for immediate naval and air concessions in British possessions in the Western Hemisphere." 365

On August 1, Herbert Agar and two other Century-Group members directly lobbied the president. Roosevelt remained somewhat

359 lbid. at 643-44 (relating a private conversation between Harry Hopkins and Churchill's private secretary). In a draft of his essay, Jackson wrote, "Britain not only won our admiration for the courage and audacity of her action lagainst the French fleet], but renewed hope in her prospects." Jackson, Draft 1-23, note 6 above, at 7. Accord, Jackson Reminiscences, note 6 above, at 888 . Nevertheless, as late as August 14, War Secretary Stimson, who fully supported providing munitions to the British, was still worried about the Germans beating the British and using captured American munitions against the United States. Telephone transcript, 14 August 1940, Morgenthau Diaries, note 23 above, Book 293, pp. 157.

360 Lord Lothian to Winston Churchill, 30 July 1940, quoted in David Reynolds, Lord Lothian and Anglo-American Relations, 1939-1940, Transactions of the American Philoshopical Society, Pt. 2, (1983), 73: at 27. In a "Personal and Confidential" letter, Fredric Coudert of Coudert Brothers wrote Secretary Stimson that the British "desperately need Destroyers." Frederic Coudert to Henry Stimson, 30 July 1940 (handwritten postscript), Henry Stimson Papers, Box 135, Yale University. See also notes 386-88 below and accompanying text.

361 See notes 268-71 above and accompanying text.

362 See Chadwin, Hawks, note 272 above, at 78-79; New York Times, 30 July 1940.

${ }^{363}$ See ibid., at 80-86.

364 Ibid., at $80-81$

365 Memorandum of Meeting, 25 July 1940, quoted in Chadwin, Hawks, note 272 above, at 85 . See also Alan Brinkley, The Publisher: Henry Luce and His American Century (New York: Alfred A. Knopf, 2010), 260-64. 
non-committal on the destroyer transfer and again expressed concern about the coming fall election. He was worried by the possibility that Willkie might refuse to endorse the deal. ${ }^{366}$ Roosevelt did suggest, however, that the Group should get in touch with General John Pershing and ask him to endorse the transfer of destroyers in a nationwide radio broadcast. ${ }^{367}$ That same day, Lord Lothian was again asking Navy Secretary Knox for destroyers, and Knox suggested the possibility of trading the destroyers for bases. Lothian jumped at the idea and told Knox that he would immediately cable the proposition to his government. ${ }^{368}$

These discussions with the President and Secretary Knox set the stage for a momentous cabinet meeting on August 2. Secretaries Knox, Stimson, and Ickes fully supported sending destroyers to Britain and conferred in the morning. At the cabinet meeting that afternoon, Knox related his discussion the night before with Lothian. ${ }^{369}$ And so began what Stimson described as "one of the most serious and important debates that I have ever had in Cabinet Meeting." ${ }^{370}$ The result was a general opinion, without any dissenting voice $^{371}$ that as a matter of policy the destroyers should be sent to Britain. Ickes noted in his diary with mild surprise, "Even Hull was in favor of doing something." 372

${ }^{366}$ Chadwin, Hawks, note 272 above, at 86-87

${ }^{367}$ Herbert Agar, The Darkest Year: Britain Alone, June 1940-June 1941 (Garden City: Doubleday, 1973), at 147. Agar relates that the President himself did not want to ask General Pershing for fear of a leak. Agar continued: to the best of his memory the President explained, "If one of you asks Pershing to make the speech, it probably won't leak. If it does, and you say the idea came from me, I will call you a liar and all would be peaceful in Congress." Ibid.

368 Ickes, Diary, note 17 above, at 283. Lothian knew that his government already had all but decided to grant the U.S. base rights. See Reynolds, Creation, note 7 above, at 122-23; Leutze, Bargaining, note 7 above, at 104-05. From the British point of view, the bases were like a tar baby: "The strategic value of these bases was that they could be used by some other Power for attack on the United States. So long as the United States were in occupation of the leased area there was no danger that they would permit the bases or the neighboring British territories to be occupied by any third nation." War Cabinet minutes, 13 March 1941, Churchill War Papers, note 1 above, at 3:348.

369 Ickes, Diary, note 17 above, at $283 \& 291$.

${ }^{370}$ Stimson Diary (2 August 1940) p. 3, note 3 above.

${ }^{371}$ Franklin D. Roosevelt, memorandum, 2 August 1940, Foreign Relations, note 77 above, at 3:58. See also, Ickes Diary, note 17 above, at 292 ("the President and the Cabinet generally were much more sympathetic to the proposition.").

372 Ibid., at 292. 
But the problems of the Walsh Amendment and the Espionage Act remained. That same day, State Department's Legal Adviser had given Hull a memorandum implying that the destroyers could not be transferred without new legislation. ${ }^{373}$ Hull therefore argued to the cabinet "that about the only way to accomplish the transfer of the destroyers to the British Government would be to repeal that old law which prohibits such sale." ${ }^{374}$ The president understood that, "It was agreed that legislation to accomplish [the transfer] is necessary." 375 The president also wanted to seek Republican support. Therefore, he decided to use William White as an intermediary to obtain support from Willkie, the Republican nominee for president; Charles McNary, the Republican vice presidential candidate and Senate minority leader; and Joseph Martin, the House minority leader. ${ }^{376}$ Apparently, Jackson either acquiesced in or agreed with the consensus that legislation was necessary. ${ }^{377}$

\footnotetext{
${ }^{373}$ Green Hackworth, Memorandum: "The Sale of Vessels of War and Auxiliary Vessels," 2 August 1940, Foreign Relations, note 77 above at 3:59-61. Hackworth's memorandum is so uninformative that he may have been intentionally striving for vagueness. He simply summarized without comment the 1794 Neutrality Act, the Espionage Act, and the Walsh Amendment and then blithely noted that the Espionage Act "is perhaps the most difficult provision of statutory law to surmount." Ibid., at 60 . He then proposed a specific statutory amendment to override the three problem statutes. He concluded by noting that his proposed amendatory language would not "relieve us of the charge that the sale of war craft by this Government to a belligerent government would be unneutral." Ibid., at 61 .
}

Unless Hackworth was striving for vagueness (and perhaps he was), his memorandum was worse than useless. He seems to say that a transfer would be illegal (Accord, Shogan, Hard Bargain, note 7 above, at 183; Fellmuth, "Divorce," note 134 above, at 473), but he does not so state. Similarly, he implies that the transfer will violate international law but limits his advice to noting that the United States will be subject to a "charge [of being] unneutral."

374 Morgenthau Diaries, 2 August 1940, note 23 above, Book 288, p. 160.

${ }^{375}$ Franklin Roosevelt, Memorandum, 2 August 1940, Foreign Relations, note 77 above, at 3:58.

376 Ibid.

377 Except for the President's general statement (see note 369 above and accompanying text), there is no record of Jackson speaking one way or another on the legal necessity of amending the laws. In a preliminary draft of his destroyer article, Jackson indicated that the August 2 consensus regarding Congress "was political rather than legal." Moreover, he continued, "the Attorney General had at that time been asked for no opinion on such a necessity." Jackson, Draft 1-16, note 6 above, at 16. Two days later, Secretary Hull sent a copy of Hackworth's memorandum (See note 369 above and accompanying text.) to the President with a note that the 
Although there was now a consensus within the cabinet, there was still a general assumption that some form of congressional approval was necessary. Two days after the meeting, Secretary Hull told the British Ambassador "nothing can be done about the destroyers until after the election." 378 The State Department also continued to have serious reservations about the legality of the deal under international law. ${ }^{379}$

\section{B. The Cohen/Acheson Redraft}

If formal congressional approval was required, the deal was in hopeless limbo. No one seriously believed that legislative action was possible in the near term. Secretary Hull was talking about seeking approval after the November elections. ${ }^{380}$ Then Justice Felix Frankfurter reentered the fray. He told Benjamin Cohen to get together with Dean Acheson, rewrite Cohen's memorandum, and present it once more to the president and the attorney general. ${ }^{381}$ In addition, he apparently participated in some way in redrafting Cohen's memorandum. ${ }^{382}$ Years later, Cohen noted that, "I was work-

memorandum had been "approved by Judge Townsend of the Department of Justice." Cordell Hull to Franklin Roosevelt, 4 August 1940, Foreign Relations, note 77 above, at 3:61.

${ }^{378}$ Goodhart, Fifty Ships, note 7 above, at 157. Accord, Memorandum of conversation, 5 August 1940, Cordell Hull Papers, Library of Congress, Washington, DC, Reel 29, container 58, folder - Great Britain 1939-40.

379 See notes 70-73 above and accompanying text.

${ }^{380}$ See Leutze, Bargaining, note 7 above, at 109.

${ }^{381}$ Bruce Allen Murphy, The Brandeis/Frankfurter Connection: The Secret Political Activities of Two Supreme Court Justices (New York: Oxford Univ. Press, 1982), 210 (Benjamin Cohen interview). Accord, Joseph Lash's Interview with Benjamin V. Cohen, 8 April 1974, Joseph P. Lash Papers, FDR Library, Hyde Park, NY.

382 During Frankfurter's years on the Supreme Court, he delighted in serving as an all-purpose legal adviser to the New Deal. See generally Murphy, Brandeis/ Frankfurter, note 381 above. He personally asked Cohen to write Cohen's initial memorandum, and he personally asked Cohen and Acheson to rewrite the memorandum. See notes $286 \& 381$ above and accompanying text. Frankfurter also asked Charles Burlingham to cosign the Times letter. See notes 392-94 below and accompanying text. At least one contemporary newspaper reported Justices Frankfurter and Murphy were counseling the president on the destroyer issue. See note 442 below. Burlingham thought that Frankfurter was involved in writing the Cohen/Acheson letter. See note 506 below. Moreover, a few days after the letter was published, Frankfurter told Secretary Stimson that he, Frankfurter, "had been thinking it over very hard for two or three days [and thought that the letter's analy- 
ing with Felix" on the destroyer issue. ${ }^{383}$ On August 7 or earlier, ${ }^{384}$ Acheson and Cohen began intermittently working on their rewrite in DC then took the train to New York, secluded themselves in Cohen's apartment, and reworked the original memorandum. ${ }^{385}$ Meanwhile, General Pershing delivered the nationwide radio address that President Roosevelt had suggested. The General explained the dire military situation and urged the transfer of "at least fifty of [our] overage destroyers" to Great Britain. ${ }^{386}$ At about the same time, retired Chief of Naval Operations William Standley delivered a nationwide address supporting the General's recommendation. ${ }^{387}$ Other respected admirals publicly concurred in Pershing's and Standley's recommendation. ${ }^{388}$ Finally, on August 4, William "Wild Bill" Donovan returned from a fact-finding mission to Great Britain. ${ }^{389}$ He assured

sis] was sound." Stimson Diaries, note 3 above (Aug. 15, 1940). Finally, years later, Cohen recalled that "I was working with Frankfurter" on the destroyer issue. See note 294 above and accompanying text.

${ }^{383}$ See note 294 above and accompanying text.

${ }^{384}$ Oscar Cox, Daily Calendar, 7 \& 9 August 1940 (noting that Cohen called twice from New York about the Helldiver deal), Oscar Cox Papers, FDR Library, Hyde Park, NY. In later years, Acheson recollected that he and Cohen worked on the letter for two weeks before it was published on August 11. Dean Acheson to J.D. Alexander 20 November 1966, Dean Acheson Papers, Box 38, Yale University. Perhaps the Times letter originated as part of the late-July full-court press. See notes 360-62 above and accompanying text.

385 Dean Acheson to Philip Goodhart, 15 February 1960, Dean Acheson Papers, Box 38, Yale University; Acheson, Morning, note 20 above, at 222.

${ }^{386}$ See Chadwin, Hawks, note 272 above, at 90-91 (quoting Pershing). For the full text of Pershing's speech, see New York Times, 5 August 1940.

${ }^{387}$ Chadwin, Hawks, note 272 above, at 92 . Standley was a member of the Century Group and Joseph Alsop helped him to craft the address. Ibid. Standley was CNO from 1933-1937, and during his tenure, he frequently served as acting Navy Secretary during the Secretary's illnesses. Navy Office of Information, Admiral William H. Standley, U.S. Navy, Deceased, 29 October 1963, in Robert B. Butler Papers, Virginia State Archives, Richmond, VA.

${ }^{388}$ Op/ed by Admiral Yates Stirling Jr., New York Times, 10 August 1940. Admiral Harry Yarnell, recent commander of the Pacific Fleet, also agreed. Ibid. (dateline 9 August).

${ }^{389}$ Shogan, Hard Bargain, note 7 above, at 134. Donovan was a World War I Medal of Honor recipient and a highly respected Republican lawyer. See Douglas Walker, Wild Bill Donovan: The Spymaster Who Created the OSS and Modern American Espionage (New York: Free Press, 2011). During World War II, he ran the Office of Strategic Services (OSS). 
the President that the British had "excellent prospects of pulling through." ${ }^{\prime 390}$

The New York Times published the Cohen/Acheson letter on Aug. 11 , but Cohen did not sign his masterpiece. ${ }^{391}$ Instead, the letter appeared as the opinion of leading members of the WASP legal establishment. In addition to Acheson, Charles Culp Burlingham signed the letter. Acheson described him as "the patriarch of the bar of the city of New York." ${ }^{392}$ Burlingham was a good friend of Justice Frankfurter and apparently signed at Frankfurter's request. Just three days before the Times publication, Frankfurter telephoned Burlingham in the evening, and the next day Burlingham wired Cohen and spoke with him by phone. ${ }^{393}$ That same day, Burlingham wrote George Rublee, who agreed to add his name to the letter. 394 Acheson also asked John Foster Dulles, who later served President Eisenhower as Secretary of State, and John W. Davis to sign, but both men refused for fear of upsetting their German clients. ${ }^{395}$ The letter's final cosigner was Thomas Thacher. ${ }^{396}$ Burlingham frankly

390 Leutze, Bargaining for Supremacy, note 7 above, at 112-113; Reynolds, Creation, note 7 above, at 126-27; Shogan, Hard Bargain, note 7 above, at 131-36.

391 Perhaps Cohen did not sign because he was Jewish. In addition, he was a high-profile member of the Roosevelt Administration, and his signature might have been viewed simply in terms of partisanship. Frank L. Polk, a well known Democrat and the Polk in the New York law firm of Davis, Polk, \& Wardwell, approved the letter but did not sign "because he feared his signature would do more harm than good." Benjamin V. Cohen to Marguerite Le Hand, 16 August 1940, President's Secretary's Files, FDR Library, Hyde Park, NY.

392 Ibid., at 223. Accord, George Martin, CCB: The Life and Century of Charles C. Burlingham New York's First Citizen, 1858-1959 (New York: Hill and Wang, 2005).

${ }^{393}$ Burlingham Appointment Diary, 8 \& 9 August 1940, Charles Burlingham Papers, Harvard Law Library, Harvard University.

${ }^{394} \mathrm{Ibid}$. 9 August 1940. Rublee described the final letter as a "legal screed' prepared by D.A.," but he believed "the conclusion reached seems to me sound andI wish it may help." George Rublee to Charles C. Burlingham, 11 August 1940, Charles Burlingham Papers, Harvard Law Library.

395 Acheson, Morning, note 20 above, at 222-23. Acheson also asked Allen Dulles, John's brother and later Director of the Central Intelligence Agency, to sign but apparently John persuaded Allen not to sign. Leonard Mosley, Dulles: A Biography of Eleanor, Allen, and John Foster Dulles and Their Family Network (New York: Dial, 1978), 104 (quoting Acheson's son-in-law). Allen was a member of the Century Group. Miller, Man From the Valley, note 272 above, at 94 .

396 Thacher was a prominent Republican who had served as a federal district judge and then as Solicitor General in the Hoover Administration. See Reminiscences of Thomas D. Thacher, Oral History Collection, Columbia University. 
told a friend, "Acheson wrote the letter, the rest of us were merely signers."397

To repeat: Cohen and Acheson actually wrote the letter. Acheson was a good choice to collaborate in the process. He was an enormously capable lawyer and a friend of Cohen. ${ }^{398}$ Moreover, he had supported providing significant military aid to the British from the very outset of the war. ${ }^{399}$ That summer, shortly after the evacuation of Dunkirk, he forcefully reiterated his position in a speech at Carnegie Hall. ${ }^{400}$ Finally, during Roosevelt's first term while serving as Under Secretary of the Treasury, he had a significant disagreement with the President over monetary policy, and Roosevelt, in effect, fired him. ${ }^{401}$ Therefore, people viewed Acheson as independent from the President.

The Times letter was an advocacy document, and-like Cohen's original memorandum - the authors began their case with an extensive review of the policy reasons for immediately transferring the destroyers to Great Britain. In this regard, they expressly relied upon General Pershing's belief that the transfer would be "not only compatible with, but is vitally important to, the safeguarding of our own national defense." ${ }^{402}$ In Acheson's and Cohen's minds, national defense was a crucial factor affecting the interpretation of ambiguous statutes. ${ }^{403}$ They also emphasized that immediate action was

${ }^{397}$ Charles Culp Burlingham to Francis Wrigley Hirst, 9 September 1940, quoted in George Martin, $C C B$, note 384 above, at 535 . Accord, George Rublee to Charles C. Burlingham, 11 August 1940, note 394 above.

${ }^{398}$ See Dean Acheson to George Rublee, 17 January 1939, in Among Friends: Personal Letters of Dean Acheson, ed. D. McLelland and David Acheson (New York: Dodd, Mead, 1980), 36-37.

${ }^{399}$ See note 52 above.

400 "A plane or a ship now at the front is worth more to us than it ever can be again. We should go to the limit of prudence in making available all that can be of use [to Britain and France]." Speech to the International Ladies' Garment Workers, 4 June 1940, extensively excerpted in Acheson, Morning, note 20 above, at 218-22.

401 See Acheson, Morning, note 20 above, ch. 9; Mclellan, Dean Acheson, note 19 above, at 26-29.

402 Dean Acheson et al., "No Legal Bar Seen to Transfer of Destroyers," New York Times, Aug. 11, 1940.

${ }^{403}$ For Cohen, see notes 300-04 above and accompanying text. In private, Acheson defended the letter by insisting that "close questions of interpretation have always been and should be resolved in consonance with the vital public interests of the sovereign whose laws are construed." McLellan, Dean Acheson, note 19 above, at 42 (quoting Acheson). 
required and that referring the matter to Congress was unnecessary because existing law already vested the President with unilateral authority to accomplish the transfer. They tacitly acknowledged that their legal analysis was subject to dispute and reassured their readers that "we would not suggest executive action without Congressional approval if we believed that a majority of the Congress was opposed to such action." 404

The two men then turned to their legal analysis and immediately grasped the nettle of the president's positive authority to dispose of the destroyers. They made no mention of Cohen's preposterous arguments that the destroyers were not combat vessels ${ }^{405}$ or that the destroyers could be struck from the Navy Register as unfit for service. ${ }^{406}$ Instead, they went directly to the idea that the destroyers could be transferred to the Army and then released by the Army under the recent legislation ${ }^{407}$ expanding the Army's authority to trade in "obsolescent . . . equipment." 408 At first glance, this argument is counterintuitive. The primary purpose of the interservice transfer statute surely was to authorize transfers between the Army and Navy of equipment and supplies that could be used by the transferee service, and the Army obviously had no use for destroyers. Acheson and Cohen tried to blunt this intuition by pointing out that there was good precedent for such interservice transfers. Cohen had not mentioned the Helldiver precedent in his original memorandum, but the Cohen/Acheson letter began its discussion

${ }^{404}$ Cohen/Acheson Letter, note 402 above.

405 See notes 311-319 above and accompanying text.

406 See notes 320-25 above and accompanying text.

${ }^{407}$ An Act to expedite the strengthening of the national defense, Pub.L. 76-703, 76 th Cong., 3d sess., ch. 508, \$1(a)(3), 54 Stat. 712. Professor Herbert Briggs of Cornell University wrote the only extended critique of the Cohen/Acheson letter. He quickly dashed off a memorandum and mailed it to Professor Jessup at Columbia University the day after the Times letter appeared. Herbert W. Briggs, Memorandum for a reply to Burlingham letter (n.d.; ca. 12 August 1940) enclosed with Herbert Briggs to Phillip Jessup (12 August 1940), Phillip Jessup Papers, Box A219, Library of Congress, Washington, DC). Briggs wanted to place the memorandum in the New York Times, but Jessup responded: "Doubt utility [of] reply." Marginalia on telegram from Herbert Briggs to Phillip Jessup (12 August 1940), ibid. Five days later, Briggs mailed the memorandum to Sen. Walsh who had it printed in the Congressional Record. 86 Cong. Rec. 10560 (20 August 1940). Briggs's critique did not address the Cohen/Acheson argument regarding transferring the ships to the Army and trading them in as obsolescent.

408 See notes $138-40$ above and accompanying text. 
of the President's authority with two paragraphs describing the Helldiver deal. As any good attorney would, Cohen was careful to verify that the planes had actually been transferred. ${ }^{409}$ If naval planes could be transferred to the Allies this way, why couldn't naval ships be transferred? ${ }^{410}$

The two attorneys then turned to the Walsh Amendment and essentially ${ }^{411}$ reiterated Cohen's original analysis that emphasized the net value of the transaction over the value of the destroyers. Notwithstanding General Pershing's speech, the basic stumbling block remained that Cohen's analysis flew in the teeth of the Walsh and Vinson Amendments. Although Acheson and Cohen must have been aware of the idea of trading the destroyers for bases, they made no mention of a trade except to note, "It is quite possible that in connection with the transfer, arrangements might be made which would increase our defensive power in this hemisphere." ${ }^{412}$

Finally, Cohen and Acheson turned to the old Neutrality Act and the Espionage Act and again reiterated Cohen's original analysis. ${ }^{413}$ They also expressly distinguished Jackson's torpedo-boat opinion using Cohen's original analysis. ${ }^{414}$ They concluded by emphasizing the need for immediate action: "To seek an unnecessary reaffirmation of these powers from the Congress now would be to run a serious danger of delay and by delay possibly to endanger the vital interests of the people of the country in keeping war from our shores." 415

${ }^{409}$ Oscar Cox, Daily Calendar, 9 August 1940, FDR Library, Hyde Park, NY.

${ }^{410}$ Congress had full knowledge of the Helldiver deal when the army's authority to trade in weaponry was expanded to encompass "military equipment, munitions, and supplies." An Act to expedite the strengthening of the national defense, 76th Cong., 3d sess., ch. 508, §1, 54 Stat. 712, discussed in 86 Cong. Rec. 7925-30 (1940).

${ }^{411}$ The letter does delve a little more into the Walsh Amendment's legislative history by noting that the Senate had loosened the Amendment's original drastic restriction. As originally drafted, the Walsh Amendment forbade the transfer of a vessel unless the Chief of Naval Operations certified that the vessel "is not essential to and cannot be used in the defense of the United States." 86 Cong. Rec. 8830 (1940) (original language; emphasis added). Senator Hill objected to the "cannot be used" language. Ibid. 8831 . If read literally, Hill pointed out that the language would preclude any transfer, even "an old musket." Ibid. The Senate agreed to strike the offending language and thereby slightly restricted the amendment's scope. Ibid.

${ }^{412}$ Cohen/Acheson Letter, note 402 above.

413 See notes 346-47 above and accompanying text.

414 See ibid.

415 Cohen/Acheson Letter, note 402 above. 
As a matter of ordinary statutory interpretation, Acheson's analytical approach in the Times letter seems inconsistent with his earlier dispute with the president over monetary policy. In that earlier episode, President Roosevelt decided that the government should manipulate the price of gold through gold purchases in order to encourage inflation. ${ }^{416}$ At the time, the Treasury was under a legal obligation to pay only $\$ 20.67$ an ounce for gold, but the President sought to up the price to $\$ 30$ or $\$ 40 . .^{417}$ When the Reconstruction Finance Corporation (RFC) came up with a highly technical and complicated scheme to bypass the $\$ 20$ ceiling through the exchange of short-term notes for gold, Acheson, who was then Acting Secretary of the Treasury during the Secretary's illness, refused. Acheson wrote his own legal opinion and concluded that the RFC scheme was "one of doubtful legality." 418 The end result was that the president removed Acheson from office. ${ }^{419}$ The Treasury Secretary told Acheson that the president insisted on "removing me from office pour encourager les autres." 420

The episode illustrates the perils of telling the president that he cannot lawfully do what he wishes to do. Acheson, himself, gleaned some lessons from the affair. During a preliminary encounter with the president, Acheson gave Roosevelt a draft document that concentrated on the limits of the president's authority. In retrospect, Acheson thought that his draft "perhaps, was too negative in telling [FDR] first, and at length, what he could not legally do instead of stressing what he could do." ${ }^{421}$ President Roosevelt did not like the draft: "It produced his querulous but interesting comment that lawyers were supposed to do the latter not the former." ${ }^{422}$ When

${ }^{416}$ The President's decision was based upon a flawed economic analysis. See Elmis Wicker, "Roosevelt's 1933 Monetary Experiment," Journal of American History 57 (1971): 864.

417 The story is well and succinctly told in McLellan, Dean Acheson, note 19 above, at 26-28. For a longer treatment, see Dean Acheson, Morning, note 20 above, at 168-94.

${ }^{418}$ Acheson's opinion and the RFC opinion are reproduced in Acheson, Morning, note 20 above, at 261-66.

${ }^{419}$ Acheson resigned at the President's request. Ibid., at 192.

$420 \mathrm{lbid}$. (emphasis original). In Candide, Voltaire wrote in respect of the $1757 \mathrm{ex}$ ecution of Admiral John Byng, "in this country [England], it is good, to kill an admiral from time to time, to encourage the others." (emphasis added).

$421 \mathrm{lbid}$. , at 178.

422 lbid. 
Acheson persisted in his view of the law, "the President . . lost patience with my objections and told the Attorney General [Homer Cummings ${ }^{423}$ ] to rule (and what to rule) on the legal question." ${ }^{\prime 424}$

Some thirty years after the dispute over monetary policy, Acheson confessed that "my thoughts about this whole episode have in some respects changed from what they were at the time." ${ }^{\mathbf{2 2 5}}$ Although he still believed that his original position was correct, he admitted that his actions were "tinged with a stubbornness and lack of imaginative understanding of my own proper role and of the President's perplexities and needs." ${ }^{426} \mathrm{He}$ wondered in retrospect: "Was [the President's position] so horrendous as to require, in the current phrase, making a federal case out of it? Today [in 1965] I am not at all sure." ${ }^{427}$

Acheson's approaches to the legal issues involved in the goldpurchase episode and the destroyer deal are antithetic. In the first, he adopted a straightforward interpretation that applied the selfevident meaning of the statutes, and he rejected a tortured and convoluted construction. In the second, he adopted a tortured, even "Jesuitical," 428 construction and rejected a straightforward interpretation of the statute's self-evident meaning. At the same time, his analyses were consistent in that each time he rendered a legal opinion consistent with his extralegal policy objective.

By the time of the destroyer deal, Acheson took the position in private that a "lawyer bends his brains to support policy." ${ }^{429}$ As a matter of policy, he firmly rejected critics who complained that:

\footnotetext{
${ }^{423}$ Like Jackson, Cummings was an advocate Attorney General who was an active partisan and was completely committed to Roosevelt's policies. See Baker, Conflicting Loyalties, note 8 above, at 77-82.

424 Acheson, Noon, note 20 above, at 186.

425 Ibid., at 190.

426 lbid., at 191.

427 Ibid.

${ }^{428}$ After the Times letter was published, Acheson, probably with tongue in cheek, wrote a supporter of his analysis, "I regard it as high praise that you found nothing Jesuitical in my arguments." Dean Acheson to Rufus J. Trimble, 14 January 1941, quoted in John T. McNay, Acheson and Empire (Columbia, MO: Univ. of Missouri Press, 2001), 46 n. 12.

${ }^{429}$ Phillip Jessup to Charles C. Burlingham, 26 September 1940, Charles Burlingham Papers, Harvard Law Library, Harvard University: "of course Dean is right in one sense and frankly avows the real difficulty which is that, as is often true, the lawyer bends his brains to support policy."
} 
the President should have gone to Congress. . . I have very little patience with people who insist upon glorifying forms on the theory that any other course is going to destroy our institutions. The danger to them [i.e., the people glorifying forms] seems not in resolving legal doubts in accordance with the national interest but in refusing to act when action is imperative. ${ }^{430}$

Similarly in 1950 Acheson, who was the Secretary of State, advised President Truman that notwithstanding the Constitution's commitment of the war power to Congress, Truman could unilaterally join hostilities against North Korea. ${ }^{431}$

\section{Attorney General Jackson's Formal Opinion}

The Cohen/Acheson letter broke the logjam regarding acting without Congressional approval. War Secretary Stimson was impressed with the letter's "very carefully worked out . . o opinion."432 The Times published the letter on August 11, and almost immediately the president asked Jackson what he thought of the letter. ${ }^{433}$ Jackson replied that the letter was already under review. ${ }^{434}$ The president was encouraged and that day or the next began consulting with members of Congress about the possibility of acting without formal legislative approval. ${ }^{435} \mathrm{He}$ had already reached out to the Republican presidential and vice presidential candidates. ${ }^{436}$ Willkie was playing coy. On August 13, White, who had had a series of personal conversations with the Republican nominee, reported that he "was confident that [Willkie] would not say anything in criticism of the destroyer transaction." ${ }^{437}$ In addition, some time on or before August 15, McNary said that he would not object to a destroyer transfer. ${ }^{438}$

${ }^{430}$ Dean Acheson to John McCloy, 12 September 1940, Dean Acheson Papers, Box 21, Yale University, quoted in McLellan, Acheson, note 19 above, at 41.

431 See McLellan, Acheson, note 19 above, at 280-82.

${ }^{432}$ Stimson Diary, 12 August 1940, note 3 above, ("This adds a little speck of light on the situation.").

${ }^{433}$ Jackson, Final Draft, note 6 above, at 95.

${ }^{434}$ Ibid., at 95-96.

435 "Report Sounding on Destroyer Sale," New York Times, 13 August 1940. According to the story, the Administration believed that the legal "difficulties ... could be surmounted . . . if Congress gave advance assurance that such a sale or exchange would be ratified." Ibid. Senators Pepper, Lee, and King were already on board. lbid.

436 See note 376 above and accompanying text.

${ }^{437}$ Stimson Diary, 13 August 1940, note 3 above.

438 Ibid. (15 August). 
At the same time, Justice Frankfurter was actively lobbying the Executive Branch behind the scene. On August 12, he was in New York and Connecticut conferring with Burlingham, Navy Secretary Knox, and Harry Hopkins. ${ }^{439}$ President Roosevelt's secretary relates that Frankfurter was a "frequent 'off the record' White House caller." 440 Given the justice's intimate relationship with the Cohen Memorandum and the Cohen/Acheson letter, ${ }^{441}$ he probably lobbied the president on the legal issues. ${ }^{442}$ On August 15, Frankfurter had a long telephone conversation with War Secretary Stimson. Justice Frankfurter told Stimson that "he had been thinking [the destroyer deal] over very hard for two or three days." ${ }^{443}$ In the conversation, Frankfurter endorsed the Cohen/Acheson opinion as "sound" and concluded that the President had unilateral authority to transfer the destroyers. ${ }^{444}$ Stimson immediately telephoned the President with the news. ${ }^{445}$

On August 13, two days after the Acheson-Cohen letter appeared, Judge Townsend told Jackson that he was "inclined to agree with the construction which the Times article gives to ... the Espionage Act." ${ }^{\prime 46}$ He did not, however, agree with the letter's discussion of legislative authority first to transfer the destroyers to the Army and then to have the Army dispose of the destroyers.

${ }^{439}$ Charles Culp Burlingham, Appointment Diary, 12 August 1940, Charles Burlingham Papers, Harvard Law Library, Harvard University.

${ }^{440}$ Grace Tully, F.D.R., My Boss (New York: C. Scribner's Sons, 1949), 290. Frankfurter's frequent, behind-the-scene participation in Executive Branch political decision is well documented. Murphy, Brandeis/Frankfurter, note 381 above.

441 See note 286 \& 381-83 above and accompanying text.

442 Nationally syndicated columnists Drew Pearson and Robert Allen reported that before August, Frankfurter and fellow justice Murphy "urged" the President to transfer the destroyers to Britain. See e.g., "Washington Merry-Go-Round," Galveston Daily News, 7 September 1940; "Washington Merry-Go-Round," Nevada State Journal, 7 September 1940. See also, 86 Cong. Rec. 11822 (9 September 1940) (Mr. Johns).

443 Stimson Diary, 15 August 1940, note 3 above.

$444 \mathrm{lbid}$. Frankfurter also told Stimson that the statutes apparently forbidding the transaction should not be interpreted as being applicable to the government: "The statute which lies in the way was a part of the old neutrality laws and was related to the matter of filibustering rather than to the matter of national defense." Ibid.

445 Ibid.

446 Newman A. Townsend, Memorandum for the Attorney General, 13 August 1940, Robert Jackson Papers, Box 88, Library of Congress, Washington, DC. 
Townsend pointed to the Vinson Amendment, which was less than a month old, as a major stumbling block. The Amendment provided that no Navy vessel "shall be disposed of by sale or otherwise, or chartered or scrapped, except as now provided by law." ${ }^{447}$ This provision was particularly troublesome because it was drafted with the disposal of destroyers to the British specifically in mind, ${ }^{448}$ and the Senate report expressly provided that the only provisions that could be used to dispose of naval vessels were 34 U.S.C. $\$ \S 491$ \& 492 dealing with vessels stricken from the Navy Register and 34 U.S.C. $\$ 493$ dealing with the sale of auxiliary vessels. ${ }^{449}$ The Report did not list the provision for interservice transfers of equipment and supplies. Townsend concluded that the interservice transfer provision could not be used and that the Walsh Amendment merely limited existing authority and was not an independent grant of authority. ${ }^{450}$ The only ray of hope that Townsend saw on this issue was a proviso in $\$ 492$ that the Supreme Court had interpreted as granting the President . . . broad discretion with respect to the method and manner of disposition [of ships struck from the Navy Register]."451

After reading Townsend's memorandum on August 13, Jackson conferred with the president ${ }^{452}$ and apparently gave Roosevelt a

44734 U.S.C. $\$ 493 a$ (1940 codification).

${ }^{448}$ Representative Vinson, who chaired the House Naval Affairs Committee, "said that he wanted this language included to stop current talk of destroyers being sold to the Allies." New York Times, 19 June 1940. See also, "Mosquito Boats Sent to Britain," Chester (PA) Times, 19 June 1940. The next day, Vinson specifically asked the Navy how many destroyers had been sold to the British. See 86 Cong. Rec. 9346 (9 July 1940) (reporting events of June 20).

${ }^{449}$ S. Rep. 76-1946, 76th Cong., 3d sess. (8 July 1940), p. 7-8.

450 Townsend Memorandum, note 446 above. Accord Conference transcript, 3 July 1940, Morgenthau Diaries, note 23 above, Book 279, p. 158 (Treasury General Counsel Foley: The Walsh Amendment "is a restrictive law. It doesn't give us authority to sell anything."); Briggs, Neglected Aspects, note 53 above, at 574 . Some ten years later, Jackson said that the Walsh Amendment "probably was a restriction, but it implied that insofar as it didn't restrict, it left a free hand." Jackson Reminiscences, note 45 above, at 902 .

451 Townsend Memorandum, note 446 above, at 5, citing Levinson $v$. United States, 258 U.S. 198 (1922). Townsend noted, "that when the provisions of section 491 have been complied with the President has broad discretion [under $\$ 492$ 's proviso]." Townsend Memorandum, note 446 above, at 5 . Although $\$ 491$ required the Navy to determine that the vessels were "unfit for further service," Townsend believed that this factual issue could be finessed: "After all is said, the question of the disposition of over-age destroyers is probably more political than legal." Ibid.

452 Jackson, Final Draft, note 6 above, at 96. 
tentative green light to transfer the destroyers without formal Congressional approval. Evidently, Jackson decided to approve the deal based upon Townsend's suggestion that Sections 491 and 492 could be used. ${ }^{453}$ The president decided to go through with the deal, ${ }^{454}$ and that same evening he sent Churchill a message that "it may be possible to furnish the British Government as immediate assistance at least 50 destroyers [and] the motor torpedo boats." 455

Meanwhile, Jackson, with the aid of Benjamin Cohen, Judge Townsend, and others, started working on his formal legal opinion. Some hitches in the negotiations between the United States and Great Britain gave Jackson and his team extra time. ${ }^{456}$ After an initial

453 See Memorandum: Old Destroyers (15 August 1940), Robert Jackson Papers, Box 88, Library of Congress, Washington, DC. The unsigned memorandum was written by Townsend and Green Hackworth. Jackson, Final Draft, note 6 above, at 96 . The last paragraph is taken word for word from Townsend's August 13 memorandum. See note 446 above.

${ }^{454}$ Doris Kearns Goodwin, No Ordinary Time (New York: Simon \& Schuster, 1991), at 142; Robert Dallek, Franklin D. Roosevelt and American Foreign Policy, 1932 1945 (New York: Oxford Univ. Press, 1979), at 245; Martin, Finest Hour, note 4 above, at 732-33; Bruff, Bad Advice, note 8, above, at 36. But see Langer \& Gleason, note 7 above, at 758-59.

${ }^{455}$ Roosevelt to Churchill, 13 August 1940, 6 p.m., Churchill \& Roosevelt: The Complete Correspondence, ed. W. Kimball (Princeton, NJ: Princeton Univ. Press, 1984), 1:58-59. Roosevelt conditioned his offer on receiving assurances from Britain regarding the Royal Navy and the lease of bases. He further noted that, "assistance ... would only be furnished if the American people and the Congress frankly recognized that in return therefore the national defense and security of the United States would be enhanced." Ibid. The President's reference to "the Congress" must have meant individual members of Congress rather than formal legislation. See notes 578-622 below, and accompanying text. He knew that formal congressional action would take months, and his use of the words "immediate assistance" clearly indicate an immediate transfer. The British understood that the offer was conditional on the transfer of bases and matters regarding the Royal Navy and not conditioned on formal congressional approval. See Gilbert, Finest Hour, note 4 above, at 732-33. Anthony Eden, who was one of Churchill's closest confidants and at the time was Secretary of State for War, understood that "[b]y August 14th ... the agreement was settled to be ratified at the beginning of [September]." Anthony Eden, The Memoirs of Anthony Eden: The Reckoning (Boston: Houghton Mifflin Co., 1965), 155. Accord Alexander Cadogan, The Diaries of Sir Alexander Cadogan, ed. D. Dilks (New York: Putnam, 1972), 321 (Permanent Under-Secretary for Foreign Affairs); Mackenzie King Report, note 246 above, at 130 (confidential statement by British Ambassador to Canada).

${ }^{456}$ In Jackson's words, "there occurred an amazing interlude of bickering between the statesmen who headed these great nations." Jackson, Final Draft, note 6 above, at 89 . There was a problem in drafting acceptable language to describe the disposition of the Royal Navy in the event of a German victory. More signifi- 
false start, ${ }^{457}$ Jackson finished a near final draft that he and the President reviewed sometime around August 22. Then Jackson deleted a significant part of the opinion, ${ }^{458}$ did some fine tuning, and released the opinion to the public on August 27.

In Steel Seizure, a little over a decade later, Justice Jackson considered the constitutional limits of presidential power. He consciously and expressly drew upon his experiences as attorney general ${ }^{459}$ to create a model involving three categories. These categories are helpful in analyzing Jackson's destroyer opinion. The first category involves presidential action taken "pursuant to an express or implied authorization of Congress." 460 In such a situation, lawful presidential power "is at its maximum, for it includes all that he possesses in his own right plus all that Congress can delegate." ${ }^{461}$ When the president acts pursuant to congressional authority, "the strongest of presumptions and the widest latitude of judicial interpretation" would be used to support the lawfulness of the president's actions. ${ }^{462}$

Jackson's second category recognizes the concept of concurrent presidential and congressional authority. If Congress has neither delegated nor denied authority to the President, "he can only rely upon his own independent powers, but there is a zone of twilight in which he and Congress may have concurrent authority, or in which its distribution is uncertain." ${ }^{463}$ Jackson confined his discus-

cantly, the British did not want to describe the transaction as a bargain for exchange involving quid pro quo. They wanted to treat the deal as an exchange of gifts. See Reynolds, Creation, note 7 above, at 127-31; Leutze, Bargaining, note 7 above, at 115-24, Jackson, Final Draft, note 6 above, at 89-91.

457 See notes $474-90$ below and accompanying text.

${ }^{458}$ See notes $536-51$ below and accompanying text.

459 Jackson's opening sentence was clearly autobiographical: "That comprehensive and undefined presidential powers hold both practical advantages and grave dangers for the country will impress anyone who has served as legal advisor to a President in time of transition and public anxiety." Steel Seizure, 343 U.S. 579, 634 (1952) (Jackson, J., concurring). He continued, "While an interval of detached reflection," i.e., about a decade, "may temper teachings of that experience, they probably are a more realistic influence on my views than the conventional materials of judicial decision which seem unduly to accentuate doctrine and legal fiction." Ibid. (Jackson, J., concurring) (emphasis added).

460 /bid., at 635 .

461 lbid.

462 Ibid.

463 Ibid. 
sion of the second category to a single, brief paragraph because he believed that the President's action in Steel Seizure was contrary to the will of Congress. ${ }^{464}$ In practice this second category, or "zone of twilight," has become very significant.

Jackson's third category involves presidential "measures incompatible with the expressed or implied will of Congress." 465 In this situation, the president's "power is at its lowest ebb, for then he can rely only upon his own constitutional powers minus any constitutional powers of Congress over the matter." 466 In other words, courts "can sustain exclusive Presidential control in such a case only be disabling the Congress from acting upon the subject." 467

\section{THE PRESIDENT'S AUTHORITY TO ACCEPT THE BASE RIGHTS}

Although the addition of bases as consideration for the destroyers greatly simplified Jackson's task, this addition required him to address the issue of whether the president had unilateral authority to accept the proffered base rights. Jackson began his opinion with this fairly technical issue. Perhaps he elected to lead with this issue because he had a strong analysis to support the president's unilateral authority. In the ordinary course of affairs, the acquisition of property rights would entail commitments that would necessitate legislative approval in the form of legislation or treaty. ${ }^{468}$ Jackson explained, however, that the president was not actually obtaining property rights with attendant commitments:

The Executive agreement obtains an opportunity to establish naval and air bases for the protection of our coastline but it imposes no obligation upon the Congress to appropriate money to improve the opportunity. It is not necessary for the Senate to ratify an opportunity that entails no obligation. ${ }^{469}$

\footnotetext{
464 lbid., at 639.

465 Ibid., at 637.

466 /bid.

467 lbid., at 637-38.

468 Jackson later related that he advised the president that an actual "cession [of territory] would probably require a treaty, and that would require ratification by the Senate." Robert Jackson, The Attorney Generalship of Robert H. Jackson at 20, in unpublished autobiography (n.d.), Robert Jackson Papers, Box 189, folder 3 , Library of Congress, Washington, DC.

46939 Op. Atty Gen., at 487. Accord, Dean Acheson to T. Jefferson Coolidge, 9 September 1940, Dean Acheson Papers, Box 6, Yale University. In contrast, an ac-
} 
In support of his analysis, he adduced a number of historical precedents. ${ }^{470}$

This part of Jackson's opinion addressed proposed presidential action that would fall into Jackson's second Steel Seizure category: the "zone of twilight" in which there is concurrent authority or the distribution of authority is uncertain. Given the lack of any binding commitments respecting the bases, Jackson concluded that the president's constitutional powers over foreign relations and as commander in chief provided ample authority to acquire the right to obtain the bases. ${ }^{471}$ This analysis is sensible and not even Jackson's most vigorous critics objected. ${ }^{472}$ Indeed, at least one of his most vigorous critics conceded in private that Jackson was probably right on this narrow issue. ${ }^{473}$

\section{THE PRESIDENT'S STATUTORY AUTHORITY TO TRANSFER THE DESTROYERS}

Jackson then turned to the similarly technical but immensely more difficult legal issue of whether the president had statutory

tual acquisition of territory would have required an act of Congress or a treaty approved by the Senate. Jackson, Final Draft, note 6 above, at 99-100. For a variety of reasons, the president consistently sought leases rather than cessions. He was particularly concerned that the southern policy of racial segregation was in sharp conflict with the existing British policy. If the British policy were continued, there would be "a row with southern representatives in Congress," but segregation "would cause grave unrest in the islands." Ibid., at 100; see also Jackson Reminiscences, note 45 above, at 896 .

47039 Op. Atty Gen., at 487-88.

471 lbid.

472 See Briggs, "Neglected Aspects," note 53 above; Edwin Borchard, "Attorney General," note 53 above, at 690-91. See also, David Levitan, "Executive Agreements: A Study of the Executive in the Control of the Foreign Relations of the United States," Illinois Law Review 35 (1940): 390-91. Professor Corwin, who strenuously disagreed with most of Jackson's opinion, quibbled with but did not seriously disagree with this aspect of Jackson's opinion. Corwin, note 308 above.

${ }^{473}$ Edwin Borchard to John Bassett Moore, 4, 28 September \& 3 October 1940, discussed in Justus Doenecke, "Edwin M. Borchard, John Bassett Moore, and Opposition to American Intervention in World War II," Journal of Libertarian Studies 6 (1982): 1. A few years later, Borchard wrote that congressional appropriations for the bases ratified the acquisition. Edwin Borchard, "Treaties and Executive Agreements-A Reply," Yale Law Journal 54 (1945): 655. 
authority to transfer ownership of the destroyers to the British. ${ }^{474}$ If Congress had delegated authority to the president, the matter fell into the first Stee/ Seizure category in which "the strongest presumptions" should be indulged to support the contemplated action. Jackson initially decided to follow Townsend's recommendation that the destroyers could be struck from the Navy Register under Section 491 and then sold to Britain under Section 492. The latter section required a detailed bid procedure, including an advertisement for not less than three months, but Townsend had pointed out a statutory fix for this glitch. Section 492's concluding proviso gave the President a general authority to accomplish the sale of struck vessels in any "manner" he saw fit. In mid-August, Jackson sent papers over to the Navy department so that the destroyers could be declared unfit for further service and struck from the Navy Register. ${ }^{475}$

Unfortunately, Jackson's initial approach fell completely apart on or shortly before August 16 when CNO Stark refused to agree that the vessels were "unfit for further service," ${ }^{476}$ as required by Section 491. Although the statute called for the fitness issue to be determined by a board of officers, ${ }^{477}$ Stark later said that if a board made such a determination, he "would disallow their finding." $478 \mathrm{He}$ ex-

${ }^{474}$ The statement in W. Bradley Wendel, "The Torture Memos and the Demands of Legality", Legal Ethics 12 (2009), 107, that the destroyers were to be leased to the British is incorrect. Jackson's opinion states, "it is proposed to transfer to Great Britain the title and possession of certain over-aged ships." 39 Op. Att'y Gen. at 485.

${ }^{475}$ See Memorandum: Old Destroyers (15 August 1940) Robert Jackson Papers, Box 88, Library of Congress, Washington, DC; Rough Draft: Steps to be Taken in Connection with the Transfer of Over-Age Destroyers (n.d., ca. 15 August 1940), Ibid.; Leutze, Bargaining, note 7 above, at 117-18.

${ }^{476}$ See CNO Stark to Navy Secretary Knox, with addenda, 17 August 1940, discussed in Leutze, Bargaining, note 7 above, at 117-19. See also 86 Cong. Rec. 12655 (1940) (Sen. Clark quotes a newspaper article relating the story of Stark's refusal). Apparently, CNO Stark's memorandum was lost in the mid-1990's, when the CNO files for 1938-41 were transferred from the Naval Historical Center to the National Archives. See Shogan, Hard Bargain, note 7 above, at 298 n. 216.

477 Jackson planned to have a "Board of Naval Officers [make the determination] in view of the strengthening of our naval bases which can be accomplished by their release." Rough Draft: Steps to be Taken in Connection with the Transfer of OverAge Destroyers (n.d., ca. 15 August 1940), Robert Jackson Papers, Box 88, Library of Congress.

${ }^{478}$ Leutze, Bargaining, note 7 above, at 118. 
plained, "such an opinion would be false else the British would not be so anxious to get the same destroyers." 479 Jackson conferred with Stark, and, echoing Judge Townsend, Jackson told Stark that the issue was more "political than legal." ${ }^{480}$ But the admiral was adamant and even suggested that he might resign rather than certify that the destroyers were unfit for further service. ${ }^{481}$ The next day, after learning of Stark's decision, ${ }^{482}$ President Roosevelt told Canada's Prime Minister that "certain legal difficulties [had] been raised and have still to be met satisfactorily but the president expects will be met by Thursday of this week [August 22]."483

August 16 was a bad day for Jackson. He had given the president a tentative green light three days earlier and that day he spent the late morning with members of the Justice Department and Benjamin Cohen "going over the statutes and cases to satisfy ourselves whether anything had been overlooked." ${ }^{484} \mathrm{He}$ lunched with Navy Secretary Knox and presented him with a one-page summary of his legal analysis. ${ }^{485}$ At this lunch, Knox presumably told him that CNO Stark was going to refuse to strike the destroyers from the Navy Register and in effect blow down Jackson's house of cards. ${ }^{486}$ Later that day, Jackson and Secretary Morgenthau conferred with the president about the contemplated trade of destroyers for bases. Roosevelt was in a positive mood, and Morgenthau "found [him] much

${ }^{479}$ /bid. (quoting Stark).

480 lbid., at 119. See also Memorandum: Old Destroyers (15 August 1940), Robert Jackson Papers, Box 88, Library of Congress, Washington, DC. This meeting took place on August 16. Jackson spent the morning conferring with Biddle, Townsend, and Cohen, he lunched with Navy Secretary Knox, and attended a cabinet meeting in the afternoon, then he and Townsend met with CNO Stark at 5:05 that evening. Manuscript schedule of meetings (n.d.), Robert Jackson Papers, Box 88, Library of Congress, Washington, DC.

481 Leutze, Bargaining, note 7 above, at 119.

482 Ibid., at 118.

483 Prime Minister of Canada to Winston Churchill, 18 August 1940, Public Records Office, London: Foreign Office files, 371, vol. 24, 242, pp 45-48.

484 Jackson, Draft 1-20, at 31, Robert Jackson Papers, Box 57, Library of Congress, Washington, DC.

485 Ibid.

${ }^{486}$ Stark formalized his decision the next day in a memorandum to Knox. See notes 476 above, and accompanying text. 
more decisive again but not unpleasantly so." ${ }^{487}$ Jackson, who knew his legal analysis was falling apart, was "not too sure of himself." 488

Although the president knew about Stark's refusal, he elected to let Jackson and Stark work out the problem themselves. Nevertheless, Roosevelt had told the Canadian prime minister that the "legal difficulties" would be resolved by August 22. When that day arrived, the president turned up the heat on Stark and Jackson. In a telephone conversation at which Jackson and Navy Secretary Knox were present, Roosevelt told the prime minister that the destroyer negotiations "were proceeding satisfactorily." ${ }^{489}$ In particular, the president noted

that a way out of legal difficulties, which had been blocking him, had at last been found. At least if it hadn't, continued the President, one of the heads now in the room (Attorney General, the Secretary of War, the Secretary of Navy and the Acting Secretary of State) will have to fall. ${ }^{490}$

When Jackson published his final opinion five days later, he had abandoned his initial idea of striking the destroyers from the Navy Register.

Instead, Jackson went straight to the concluding proviso of Section $492 .{ }^{491}$ Most of the section dealt with detailed procedures that

\footnotetext{
487 Morgenthau Presidential Diary, note 260 above, Bk 2, p. 643.

488 Ibid., at 644.
}

489 Jay Pierrepont Moffat, Diplomatic Journal, Ottawa 1940-1941, 22 August 1940 , Jay Pierrepont Moffat Papers, Harvard University. The Canadian Prime Minister recounted the conversation to Ambassador Moffat that same day.

490 /bid. In all likelihood, the president's threat was delivered with a smile. $C f$. Owen Wister, The Virginian (New York: Macmillan Co., 1919), 24 ("When you call me that, smile.") (emphasis original). But the president had a nasty habit of joking with subordinates at their expense. Francis Biddle, who succeeded Jackson as attorney general, related that, "[h]owever genial [Roosevelt's] teasing, it was often, when he felt in that particular mood, pointed with a prick of torment, and went to the essence of a man, pierced him between the ribs into the heart of his weakness." Francis Biddle, In Brief Authority (Garden City, NY: Doubleday \& Co., 1962), 5.

${ }^{491}$ Perhaps the idea of relying solely upon Section 492 's proviso came initially from Robert Stern. Fifty years later, Stern remembered that

President Roosevelt ... sought an opinion as to the legality of [the destroyer deal] from the Attorney General. Jackson requested, but did not receive, a persuasive opinion to that effect from the high-ranking Justice Department attorney who usually wrote the Attorney General's opinions [i.e., Judge Townsend's recommendation discussed in notes $446 \& 470-78$ above and accompanying text], and requested me to prepare a new opinion. He found my draft satisfactory! 
the Navy Secretary should use in disposing of ships stricken from the Navy Register, and the proviso modified this authority by providing "no vessel of the Navy shall hereafter be sold in any other manner than herein provided, or for less than such appraised value, unless the President of the United States shall otherwise direct in writing." ${ }^{492}$ Jackson then quoted the Levinson case that Townsend had pointed out in his August 13 memorandum. He noted that the Court had held that the president's power extended not just to the issue of appraised value, but also to the more general restriction that "no vessel ... shall hereinafter be sold in any other manner than herein provided." 493 Jackson then concluded, "So far as concerns this statute, in my opinion it leaves the President as Commander in Chief of the Navy free to make such disposition of naval vessels as he finds necessary in the public interest." ${ }^{\text {494 }}$

Judged by the standards of traditional legal analysis, Jackson's analysis of Section 492 was clearly erroneous. Section 492 was clearly linked to Section 491, and the two sections formed a comprehensive approach to the disposal of naval vessels. ${ }^{495}$ The first section established a procedure for striking vessels from the Navy Register, and in particular, required a finding that the vessel be "unfit for further service." The second section authorized the sale of stricken vessels and provided the procedures for accomplishing the sale. Jackson could not admit this clear linkage in his opinion because Admiral Stark had refused to find that the vessels could be struck from the Register.

Robert L. Stern, "Reminiscences of the Solicitor General's Office," Supreme Court Historical Journal 1995 (1995): 127. Stern later was the co-author of a well regarded book on Supreme Court practice. He served in the Department of Justice from 1933 to 1954 and left government service as the acting Solicitor General. Ibid.

49239 Op. Atty. Gen. 484, 489, quoting 34 U.S.C. $\$ 492$ (1940 codification).

493 Levinson v. United States, 258 U.S. 198, 201 (1922).

49439 Op. Atty. Gen. 484, 489.

495 In 1882, Congress created the Section 491 procedure that authorized the Navy Secretary to strike vessels "unfit for further service" from the Navy Register. Act of 5 August 1882, ch. 391, \$2, 22 Stat. 196. The next year, Congress enacted Section 492 to provide a detailed procedure for selling ships struck from the Register. Act of Mar. 3, 1883, ch. 141, $\$ 5,22$ Stat. 599. Section 492 expressly provides that it establishes procedures for selling ships struck from the Register. 
Section 492's title in the United States Code was "Sale of vessels stricken from register" 496 and the first 55 lines of the section dealt with the manner in which stricken vessels were to be sold. The mandated procedure for sale required, among other things, an appraisal of the vessel, advertisement of the sale in newspapers, sealed bids, and sale to the highest bidder. Having laid out in detail the manner in which the vessels were to be sold, the section concluded with a 5 -line proviso that "no vessel ... shall be sold in any other manner than herein provided, or for less than appraised value, unless the President . . . shall otherwise direct." Jackson's opinion decoupled the proviso from the statute and read it as a general authorization to sell any vessel that the president might wish. Usually provisos are interpreted as being applicable only to the provision to which they are attached. . $^{497}$ The purpose of Section 492 was to set up complex and detailed procedures for selling vessels struck from the Navy List. Therefore, the concluding proviso should have been read as merely empowering the president to vary the procedures set out in the statute. Moreover, the plain language of the proviso says as much. It empowered the president to depart from the "manner" or procedure used to accomplish the sale.

Although Jackson made much of the Supreme Court's decision in Levinson, the decision in no way supported his opinion. Levinson involved a yacht that had been taken by the Navy for use during World War I, and at the conclusion of the war, the Navy had no further use for it. The Navy struck the yacht from the Register, ${ }^{498}$ and the President by Executive Order directed that vessels like the yacht should be sold under procedures that deviated from Section 492.499 The Supreme Court interpreted the statute's proviso as allowing a deviation from the general requirement that vessels stricken from the Navy Register were to be sold to the high bidder. In other words, the case had nothing whatsoever to do with the President's authority to sell vessels and was entirely concerned with the President's

\footnotetext{
496 The title of an act is not, itself, legislation, but courts from Jackson's era were willing to look at a title as an aid to resolving an ambiguity. See, e.g., Lapina $v$. Williams, 232 U.S. 78 (1914); Fairport P\&E. R. Co. v. Meredith, 292 U.S. 589 (1934).

${ }^{497}$ See, e.g., Cox v. Hart, 260 U.S. 427 (1922); United States v. McClure, 305 U.S. 472 (1939).

498 See United States v. Levinson, 267 F.692, 692 (2d. Cir. 1920). See also, Levinson v. United States, 258 U.S. 198, 202 (1922) (McKenna, J. dissenting).

${ }^{499}$ See Exec. Order No. 3021 (7 January 1919).
} 
authority to determine the manner in which a vessel, properly struck from the Navy Register, would be sold.

The recently enacted Vinson Amendment was the final nail in the statutory coffin. The Amendment's purpose obviously was to restrict the president's authority to dispose of naval vessels, ${ }^{500}$ and Congress specifically had a possible destroyer transfer in mind when it enacted this limiting legislation. ${ }^{501}$ Notwithstanding this purpose, Jackson construed Section 492 and the Vinson Amendment as giving the President plenary power to dispose of any vessel that he saw fit to sell. In effect, Jackson's construction limited the 5-weekold Vinson Amendment to oral contracts and to sales made by subordinates without the president's approval. ${ }^{502}$ Congress could not possibly have had this absurd purpose in mind. Under Jackson's misconstruction, the recently enacted Vinson Amendment served no plausible purpose.

Until Jackson advanced his unwarranted construction, every lawyer who considered the issue thought that Section 492's proviso was limited to vessels stricken from the Navy Register. Benjamin Cohen, who had "the best legal brains [Jackson had] ever came in contact with," ${ }^{203}$ carefully read Sections 491 \& 492, specifically noted the existence of the proviso, and concluded that it was subject to the general requirement of striking a vessel from the Navy Register. ${ }^{504}$ When Acheson and Cohen rewrote Cohen's memorandum, they dropped Sections 491 \& 492 all together from their analysis. ${ }^{505}$ Jackson's Section 492 analysis puzzled Charles Burlingham, ${ }^{506}$ who had signed the Times letter. ${ }^{507}$ When Judge Townsend

${ }^{500}$ See notes 189 \& 448 above, and accompanying text.

501 See note 448 above and accompanying text. See also, notes $172-90 \& 336$ above and accompanying text.

${ }^{502}$ Section 492's proviso required the President to approve a sale in writing. 34 U.S.C. $\$ 492$ (1940 codification).

503 See note 18 above and accompanying text.

${ }^{504}$ See, notes 320-22 above and accompanying text.

505 Acheson apparently disagreed with Jackson's Section 492 analysis but would not say so in public. See Dean Acheson to Thomas Thacher, 19 March 1941, Charles C. Burlingham Papers, Harvard Law Library.

${ }^{506}$ Burlingham thought that Justice Frankfurter had participated in drafting the Cohen/Acheson redraft. See Charles Burlingham to Felix Frankfurter, 14 August 1940 ("Who inspired our letter? You?"), Felix Frankfurter Papers, Library of Congress, Washington, DC. Jackson's official opinion puzzled Burlingham, but he did not write either Cohen or Acheson. Instead, he asked Frankfurter, "Why did not 
reassessed the issues in his August 13 memorandum, he pointed out the proviso to Jackson ${ }^{508}$ and suggested that, "It may be, however, that immediate release and sale of the over-age destroyers could be accomplished under sections 491 and 492."509 Townsend clearly saw the two sections as being linked, and in addressing the proviso, he concluded "when the provisions of sections 491 [i.e., striking from the Register] have been complied with the President has broad discretion with respect to the method and manner of disposition." ${ }^{10}$ Finally, Jackson, himself, initially adopted this analysis and did not abandon it until Admiral Stark refused to go along with the vital finding of fact.

Although Cohen and Townsend participated in drafting Jackson's opinion, the opinion gives no hint of why Jackson rejected their shared statutory interpretation or indeed his own, initial opinion. The only reference to the issue was an absurd and unsupportable statement that, "I find nothing that would indicate that the Congress has tried to limit the President's plenary powers to vessels already stricken from the naval register." ${ }^{111} \mathrm{He}$ cannot have believed this bald assertion. When he talked about the Destroyer Deal in later years, he glossed over this glaring problem. In his oral history, he said that the Walsh Amendment "probably was a restriction, but it implied that insofar as it didn't restrict, it left a free hand." 512 Sim-

our letter instant discuss [Section 492 and] Levinson." Charles C. Burlingham to Felix Frankfurter, 4 September 1940, Felix Frankfurter Papers, Library of Congress, Washington, DC. When a letter from New Milford, CT, was published in the Herald Tribune in full support of a destroyers-for-bases deal, Burlington assumed that it was written under Frankfurter's influence. Charles $C$. Burlington to Benjamin V. Cohen, Aug. 26, 1940, Benjamin Cohen Papers, Box 7, Library of Congress, Washington, DC ("It . . . must have been written suboculo Felicis F.").

s07 See notes 392-94 above and accompanying text.

${ }^{508}$ He quoted Sections 491 and 492 and underscored the proviso. Townsend Memorandum, note 446 above.

509 lbid.

510 lbid.

51139 Op. Atty. Gen. 484, 489 (1940).

512 Jackson Reminiscences, note 45 above, at 902 . Accord, Kimball, Unsordid Act, note 127 above, at 46 . Jackson also stated that his destroyers opinion "approved the transfer of the destroyers, because they fell in the classification of obsolescent." Ibid., at 900 . The proviso to Section 492, however, made no mention of obsolescence. Jackson was speaking about ten years later and apparently conflated his opinion with the New York Times letter in which Cohen and Acheson relied in part on the statute that allowed the disposal of "obsolescent . . . material." See notes 407-410 above and accompanying text. 
ilarly, in his unpublished law review article on the Destroyer Deal, he suggested that his opinion was based on Townsend's August 13 memorandum. Jackson wrote, "Judge Townsend, with a caution typical of his work, concluded that there was a basis in existing statutes probably sufficient for Presidential disposition of the over-age destroyers." 513 Of course, Townsend actually concluded that striking the destroyers from the Navy Register was a prerequisite to the president's authority, and Jackson initially agreed.

\section{THE WALSH AMENDMENT}

Having concluded, albeit erroneously, that Section 492 granted the President a plenary, unilateral authority to dispose of warships, Jackson immediately turned to the Walsh Amendment. As a preliminary matter, he noted and sidestepped a theoretical constitutional objection to the Amendment. ${ }^{514}$ Like all good statutory analyses, he

513 Jackson, Final Draft, note 6 above, at 96.

${ }^{514}$ On its face, the Amendment gave conclusive authority to the Chief of Naval Operations and the Army Chief of Staff to determine whether equipment was "essential" to national defense. General Marshall and CNO Stark believed that this delegation unconstitutionally interfered with the President's authority as commander in chief. Marshall Papers, note 101 above, 2:262 n.1; Chadwin, Hawks, note 267 above, at 84 . Jackson agreed that "to prohibit action by the constitutionally created Commander in Chief except upon authorization of a statutory officer subordinate in rank is of questionable constitutional authority." 39 Op. Atty Gen., at 490. See also Steel Seizure Case, 343 U.S. 579, 644 (1951) (Jackson, J., concurring: "Congress cannot deprive the President of the command of the army and the nav"); ibid., at 645-46. He avoided the issue, however, by noting that the President would in any event wish to consult the nation's chief military officers on this issue and the statute's legislative history indicated that "no arbitrary restriction was intended." Ibid. Therefore, "it seems unnecessary to raise the question of constitutionality which such a provision would otherwise invite." Ibid.

In an embarrassing passage, Professor John Yoo tells us that in this part of the opinion Jackson questioned the constitutionality of any Congressional effort to limit the President's power. Professor Yoo cherry picks two words from Jackson's opinion and tells us that Jackson wrote, "Any statutory effort by Congress to prevent the President from transferring military equipment to help American national security would be of "questionable constitutionality." John Yoo, Crisis and Command (New York: Kaplan, 2009), 300. Of course, Jackson made no such general claim. Accord, Julian Mortenson, "Executive Power and the Discipline of History," University of Chicago Law Review 78 (2011), at 377-78. Indeed, in Steel Seizure, he explicitly denied that his opinion on the President's authority to transfer the destroyers was premised on the president's constitutional power as commander-inchief. 343 U.S., at 645-46. 
began with the words of the statute that forbade the sale of a warship unless the vessel "is not essential to the defense of the United States." 515 At first glance, the act seemed to ask whether the vessels were intrinsically essential to the nation's defense, and Jackson began his analysis by noting that the destroyers were "over-age." Nevertheless, he recognized the painfully obvious fact that the ships "have been reconditioned and are in service." ${ }^{17}$

Because the ships actually were in service, they clearly were contributing to national defense. Jackson pointed, however, to the legislative history that established with equal clarity that Congress did not seek to bar all transfers of ships that could be used for national defense. ${ }^{518}$ Although the Walsh Amendment required the government to consider the destroyers' intrinsic value, Jackson insisted, that the government should "also [consider] what the government receives." ${ }^{19}$ He concluded that the Walsh Amendment allowed a transfer of the destroyers "if . . . the exchange of such destroyers for such naval and air bases will strengthen rather than impair the total defense of the United States." ${ }^{20}$ This analysis was consistent with the words and the purpose of the Walsh Amendment. Although Walsh was generally opposed to any action that might embroil the country in war, ${ }^{521}$ Walsh stated and restated that the purpose of his amendment was to enhance national defense by preventing the transfer of any ships that "we need for our defense." 522

\footnotetext{
515 An Act to expedite national defense, and for other purposes, Pub.L. 76-671, 76th Cong., 3d sess., ch. 440, $\$ 14(a), 54$ Stat. 676, 681.

51639 Op. Atty Gen., at 491.

517 lbid.

518 Ibid., at 491-92.

$519 \mathrm{lbid}$., at 492. Jackson then added an Every-Man touch: "In this situation good business sense is good legal sense." Ibid.

520 Ibid., at 493 . In the same paragraph, he gave a slightly different interpretation of the statute.

521 See 86 Cong. Rec. $8782-84$ (June 21, 1940).

522 See ibid., at $8830 \& 8831$. Earlier that day, Walsh explained: "If I have been sensitive and keen about the least interference with our defenses, it is because of two reasons: First, I want our defenses so complete and so powerful that they will prevent any violent-minded enemy from successfully attacking us; and, second, I do not want our forces deprived of one gun, or one bomb, or one ship which can aid the American boy whom you and I some day may have to draft." Ibid., at 8784 .
} 
Jackson's legal analysis of the Walsh Amendment was as powerful as his Section 492 analysis was weak. He did more than restate the argument that Cohen developed in July and that Cohen and Acheson used in their letter to the Times. The chief difference was in the national defense benefits to be received for the destroyers. In the earlier analyses, the United States would have received an inconsequential ${ }^{523}$ sum of money and the intangible benefit of having the destroyers go into service immediately against Germany. In contrast, the reshaped deal gave the United States tangible bases that clearly would benefit national security. The purpose of the Walsh Amendment obviously was to further national defense. Relying upon this purpose, legislative history, and the words of the statute, Jackson interpreted the statute as not forbidding a transaction whose net effect was clearly to enhance national defense. There can be no stronger statutory analysis.

\section{THE ESPIONAGE ACT}

Finally, Jackson turned to the thorny issue of the Espionage Act and simply reiterated Cohen's original analysis that Cohen and Acheson had restated in their letter to the Times. ${ }^{524}$ Jackson also

\footnotetext{
${ }^{523}$ See Jackson, Final Draft, note 6 above, at 97 . Accord, 86 Cong. Rec. 10404 (15 August 1940) (Mr.Tydings).

524 See notes $413-14$ above and accompanying text. Some critics have charged that Jackson's opinion distorted the Espionage Act's meaning by adding a comma to the statute. Borchard, "Attorney General," note 53 above, at 693-94. See also Daniel Patrick Moynihan, On the Law of Nations (Cambridge, MA: Harvard Univ. Press, 1990), 71-72 (apparently relying on Borchard). The Act, with the surplus comma in brackets, read as follows:
}

During a war in which the United States is a neutral nation, it shall be unlawful to send out of the jurisdiction of the United States any vessel[,] built, armed, or equipped as a vessel of war, or converted from a private vessel into a vessel of war, with any intent or under any agreement or contract, written or oral, that such vessel shall be delivered to a belligerent nation, or to an agent, officer, or citizen of such nation, or with reasonable cause to believe that the said vessel shall or will be employed in the service of any such belligerent nation after its departure from the jurisdiction of the United States.

Moynihan calls the surplus comma the "comma that saved a kingdom." Moynihan, Law of Nations, this note, at 189 n 25. Notwithstanding Moynihan's wit, if the comma is deleted, the statute is still ambiguous. See note 347 above and accompanying text. 
reiterated the distinction that Cohen had originally drawn between the destroyers and the torpedo boats. Elco was still building the boats. If the government transferred these boats while they were still under construction, the boats would be finished by Elco with an intent to transfer them to a belligerent nation.

\section{ROADS NOT TAKEN}

An early draft of the opinion placed surprising emphasis upon a claimed exclusive executive power of the President. Insofar as the president's unilateral power to acquire bases from the British is concerned, the early draft opens with a flat pronouncement that "eminent authorities have long held that in the field of foreign relations the Executive's power is both complete and exclusive." 525 This sweeping claim of Executive power, however, is not as broad as it seems. The argument was advanced to support implicit Executive power to acquire rights to bases in the absence of Congressional guidance. There was, of course, no act of Congress forbidding the president to acquire the base rights.

After concluding on the basis of the president's broad foreign affairs powers that the president could acquire the base rights, the early draft turned to the far more difficult issue of whether the president could sell the destroyers. The relevant legislation seemed to bar the sale. If so, the contemplated deal would have been within the third Steel Seizure category in which the president's "power is at its lowest ebb." The early draft began its analysis of this problematic issue by baldly asserting, "[i]n view of your constitutional power as Chief Executive and as Commander in Chief of the Army and Navy, many authorities hold that the Congress could not by statute limit your authority in this respect." 526 The idea may have come from

525 Preliminary Draft Opinion (n.d.; ca. Aug. 16, 1940), Benjamin Cohen Papers, at 1, Library of Congress, reprinted in William R. Casto, "Attorney General Robert Jackson's Brief Encounter with the Notion of Preclusive Presidential Power," Pace Law Review 30 (2010): : Appendix, at 383-95.

526 Ibid., at 3-4. Less than a month later, James W. Ryan made the same claim of unilateral unreviewable presidential power to support the Destroyers-for-Bases Deal. "Address to the American Bar Association Section of International Law," (10 September 1940), 86 Cong. Rec. App. 5600-03 (1940). Mr. Ryan urged that "statutes purporting to restrict the President's constitutional powers and action in protecting the country by action of an executive nature in the military field and in the field of 
War Secretary Stimson. 527 The draft's breathtaking suggestion of unilateral dictatorial power is the broadest claim of presidential power in the nation's history. ${ }^{528}$ Whoever penned this early draft must have realized how obnoxious the suggestion was and immediately began back peddling: "I find it unnecessary, however, to pass upon that question [of unilateral, unreviewable Presidential power]."529 The issue was not presented because the opinion concluded that Congress had expressly given the president authority to transfer the destroyers and that neither the Walsh Amendment nor the Espionage Act barred the President from exercising the authority granted. 530

At some point someone, perhaps Jackson or surely with Jackson's approval, struck the unilateral, unreviewable power argument from the opinion. ${ }^{531}$ The reasons for deleting the claim of an extensive unreviewable presidential power are unclear. None of the authorities cited in the preliminary draft supported the proposition. ${ }^{532} \mathrm{Cer}$ -

foreign relations" were invalid. Ibid., at 5601 . Most of his comments, however, went to an extended argument that the relevant statutes should not be construed as restricting the president's exclusive unilateral powers.

527 Jackson's untitled preliminary notes for law review article (n.d., ca. 1952) ("Not rest on Stimson ground inherent power"), Jackson Papers, Library of Congress, Washington, DC. Jackson further noted that in "Retrospect ... not go in inherent powers. no danger." Ibid. On September 9, 1940, Stimson wrote, "The chief hold of the Congress on the Executive is their ability to vote or to refuse to vote supplies for an Army or their right to raise and support armies in the Constitution. The more I run over the experience of the summer, the more I feel that that ought to be substantially the only check; that these other little petty annoying checks placed upon the Commander-in-Chief do an immense amount more harm than good and they restrict the power of the Commander-in-Chief in ways in which Congress cannot possibly wisely interfere. They don't know enough." Stimson Diary, note 3 above, (9 September 1940).

528 The recent frightening and frivolous pretensions of the Bush II Department of Justice were, in theory, limited to situations when the nation is at war. The nation was not at war in the summer of 1940.

529 Preliminary Draft Opinion, note 525 above, at 390

$530 \mathrm{Ibid}$.

531 Professor Barrett has accurately pointed out to me that there is no direct evidence that Jackson ever saw this draft language. The draft, itself, is in the Cohen Papers. Cohen, however, directly participated in crafting Jackson's opinion, Jackson also surely participated in the drafting process, and the final opinion was Jackson's. This circumstantial evidence leads me to conclude that more likely than not, Jackson knew about this draft language.

532 See Casto, "Robert Jackson," note 525 above, at 376-78 \& 384-89. 
tainly when Jackson served on the Supreme Court, he was dubious of a broad and unreviewable presidential authority. ${ }^{533}$ Moreover, as a matter of political maneuvering, he probably believed that a general claim of such a broad power would have unnecessarily angered Congress. ${ }^{534}$ By Aug. 22, when Jackson gave his near final draft opinion to President Roosevelt for review, the obnoxious argument was gone. ${ }^{535}$

The near final draft that Jackson gave the president had a second argument that Jackson also dropped from the final opinion. The initial Cohen Memorandum argued that neither the old 1794 Neutrality Act nor the Espionage Act barred the United States, itself, from transferring destroyers directly to the British. ${ }^{536}$ Cohen explained, "It is a general rule of statutory construction that a statute does not ordinarily apply to the government unless it is made expressly applicable to the government." 537 This sentence appears, virtually verbatim, in the near final draft that President Roosevelt reviewed. ${ }^{538}$ Although the president apparently made no comments about this analysis, Jackson struck the entire idea from his final opinion..$^{539}$

As a matter of pure legal analysis, the decision to drop this argument is difficult to understand. Jackson's task was to explain why the Espionage Act did not apply to the proposed destroyer deal. He did so by drawing a distinction that he admitted was "hairsplitting,"540

533 See ibid., at 379-80. On the other hand, Professor John Q. Barrett has pointed out to me that Jackson's subsequent experience as the prosecutor at Nuremberg undoubtedly heightened his concerns about unbridled executive power. This insight from the foremost student of Jackson's life cannot be ignored.

534 See Casto, "Robert Jackson," note 525 above, at 381.

535 Draft of opinion re sale of over-age destroyers to Great Britain with the President's emendations (n.d.; ca. 22 August 1940, Robert Jackson Papers, Box 57, Library of Congress, Washington, DC.

${ }^{536}$ See note 349 above and accompanying text

${ }^{537}$ Cohen Memorandum, note 296 above, at 10-12 $n^{*}$, citing Dollar Savings $v$. U.S., 86 U.S. 227, 239 (1873); U.S. v. Herran, 87 U.S. 251 (1874); Calif. Iron Yards Co. v. Comm. Internal Revenue, 47 F. 2d 514 (9th cir. 1931).

538 Draft with president's emendations, at 14, Robert Jackson Papers, Box 88, Library of Congress, Washington, DC. The only change was to shift the word "expressly" to a latter portion of the sentence.

53939 Op. Att'y Gen 484(1940). See draft incorporating the President's comments but $x$-ing out Cohen's idea. Draft, at 15-16, Robert Jackson Papers, Box 88, Library of Congress, Washington, DC.

54039 Op. Att'y Gen 495 (1940) relying upon and quoting Lauterpacht's Oppenheim, note 62 above, at 574-76. 
and history has not been kind to his hairsplitting. As soon as the opinion was published, critics heaped disdain on this analysis. ${ }^{541}$ More recent critics have condemned the distinction as "contrived,"542 "sophistic at best," 543 and "not a persuasive legal opinion." 544 All of these critics were quite wrong about the Walsh Amendment, but their disdain for the Espionage Act analysis is understandable.

Even those who on balance supported Jackson's opinion disagreed with his analysis of the Espionage Act. Professor Quincy Wright wrote that the "Attorney General's construction of the statute is by no means convincing." 545 Nevertheless, Wright believed that the deal was lawful because the Espionage Act "is a criminal stature presumably dealing with acts of individuals, not of the government."546 Likewise, Professor Manley Hudson, apparently Justice Felix Frankfurter, and others advised in private that the statute should be construed as not applying to the government. ${ }^{547}$

541 Briggs, "Neglected Aspects," note 53 above, at 575-87; Borchard, "Attorney General," note 53 above, at 693-96. See also, Edward Corwin, "Executive Authority," note 308 above, at E6.

542 Fellmeth, "Divorce," note 134 above, at 474 (1997). See also, ibid., at 477 ("dubious"). L.A. Power, "The Court's Constitution," University of Pennsylvania Journal of Constitutional Law 12 (2010): 534 ("probably illegal"). William Castle to Edwin Borchard 6 November 1940 ("casuistry"), Edwin Borchard Papers, Box 2-30, Yale University; Harry Jones, "The President, the Congress, and Foreign Relations," California Law Review 29 (1941): 566 ("somewhat strained").

543 Peter Margulies, "When to Push the Envelope: Legal Ethics, The Rule of Law, and National Security Strategy," Fordham International Law Journal 30 (2007): 667 See also Arthur Krock, "Helping the President Pick a Chief Justice," New York Times, 18 September 1952 ("brilliant casuistry").

544 Jack Goldsmith, "Reflections on Government Lawyering," 205 Military Law Review (2010), at 198. See also Bruff, Bod Advice, note 8 above, at 40 ("strained but not wholly untenable"). Daniel Patrick Moynihan contended that in relying upon Jackson's opinion, Roosevelt "subverted the law." Daniel Patrick Moynihan, On the Law of Nations (Cambridge, MA: Harvard Univ. Press, 1990), at 72.

545 Wright, "Transfer," note 53 above, at 683. See also Quincy Wright to Dean Acheson, 4 September 1940, Dean Acheson Papers, Box 38, Yale University.

546 Ibid., at 684, Accord Frank H. Sloss to Dean Acheson, 16 October 1940 (detailed analysis by a capable practitioner), Dean Acheson Papers, Box 38, Yale University. In private, Professor Wright wrote Charles Burlingham that in view of the difficulties with Jackson's analysis, "it seems to me much better to take a different legal line [i.e., the Act does not apply to the government]." Quincy Wright to Charles C. Burlingham, 21 August 1940, Benjamin Cohen Papers, Library of Congress, Washington, DC. See also Charles C. Burlingham to Felix Frankfurter, $28 \mathrm{Au}$ gust 1940, Felix Frankfurter Papers, Box 34, Library of Congress, Washington, DC.

547 Manley Hudson to Charles Burlingham, 12 November 1940, Benjamin Cohen Papers, Library of Congress, Washington, DC. For Frankfurter see note 444 above. 
So why did Jackson drop his best argument? Benjamin Cohen, who participated in drafting the official Jackson opinion,548 "wholly agree[d] that the [Espionage Act] does not prevent sending the destroyers out of the country by the Government itself." ${ }^{499}$ Cohen explained, however, that "such a view seemed to us calculated to produce the protest that we were putting the Government above the law and suggesting that it do what its citizens were forbidden to do." 550 Although this political concern is plausible and probably factored into the decision to drop the strongest argument, it is interesting that President Roosevelt apparently did not object to the argument when he read the near final draft of Jackson's opinion. Surely, the president was the final arbiter of all significant political decisions.

There was another possible reason for dropping the strongest argument. Jackson's earlier torpedo-boat opinion exerted an unseen, gravitational pull on his destroyer analysis. The president's cancellation of the torpedo-boat deal, ostensibly on the basis of Jackson's opinion, established a political-though technically not a legalpostulate: Federal law forbade the transfer of torpedo-boats. In an August 16 meeting, Jackson and Morgenthau persuaded the president that giving the PT boats to the British was not politically expedient: "Jackson and I persuaded not to include the 20 speed boats (70 footers) at this time as congress had turned it down once."551 Therefore, any analysis that supported transferring destroyers had

Mr. Ryan in his address to the ABA (see note 526 above) reached the same conclusion. 86 Cong. Rec., at App. 5601.

548 Jackson Reminiscences, see note 45 above, at 898 .

${ }^{549}$ Cohen's draft of a proposed letter from Dean Acheson to Quincy Wright (n.d.), Benjamin Cohen Papers, Library of Congress, Washington, DC. After reading Acheson's New York Times letter, Professor Wright wrote Charles Burlingham, one of Acheson's cosigners, and suggested that the Act would have no applicability if the Government itself transferred the destroyers to the British. Quincy Wright to Charles Burlingham, 12 August 1940, Benjamin Cohen Papers, Library of Congress, Washington, DC. Cohen prepared the draft response and sent it as an enclosure to Dean Acheson. Benjamin Cohen to Dean Acheson, 21 August 1940, Benjamin Cohen Papers, Library of Congress, Washington, DC.

550 Cohen's draft, note 549 above. Accord, Benjamin Cohen to Dean Acheson, 27 August 1940, Benjamin Cohen Papers, Library of Congress, Washington, DC.

551 Henry Morgenthau Jr.s notes of a meeting, Morgenthau Presidential Diaries, note 482 above, Bk 2, p. 643. The President, however, was not entirely convinced. See Mackenzie King to Winston Churchill, 18 August 1940, discussed in note 218 above. 
to distinguish transferring torpedo boats. Jackson's admittedly hairsplitting distinction between the obsolete destroyers that had already been built and the yet-to-be-finished torpedo boats accomplished this feat. In contrast, an interpretation that the Espionage Act limitation did not apply to direct transfers by the government itself would be equally applicable to transferring torpedo boats. Therefore, the government's best argument had to be excised from the opinion.

The contemporary reactions to the Destroyer Deal and Jackson's opinion were mixed. Confirmed isolationists loathed the deal, but most Americans thought it was a good idea. ${ }^{552}$ American lawyers with an interest in foreign relations and international law rushed a number of thoughtful critiques of Jackson's opinion to print. Much of the criticism centered on and deplored the opinion's international law implications and begged the question by assuming the continuing validity of the Hague Convention's rules of neutrality. ${ }^{553}$ Given the Roosevelt Administration's eventual and accurate position that the Hague Convention's rules of neutrality were no longer the law, ${ }^{554}$ this criticism was beside the point.

552 See Robert Dallek, Franklin D. Roosevelt and American Foreign Policy, $1932-$ 1945 (New York: Oxford Univ. Press, 1979) at 247; Langer \& Gleason, note 7 above, at 770-72.

553 Briggs, "Neglected Aspects," note 53 above, at 580-84 \& 587; Borchard, "Attorney General," note 53 above, at 695-97; Preuss, "Concepts of Neutrality," note 85 above, at 105-06. See also Josef Kunz, "Neutrality and the European War 19391940," Michigan Law Review 39 (1941):752-54.

554 See note 52 above and accompanying text. Jackson dodged the issue of whether the transaction was permissible under international law. About a half a year later, the Administration presented its position regarding international law in a speech to have been delivered by Jackson in Havana, Cuba. "Address of Robert H. Jackson, Attorney General of the United States, International Bar Association, Havana, Cuba," American Journal of International Law 35 (1941): 348 . The speech essentially adopted Benjamin Cohen's analysis in his July memorandum. Compare ibid. with note 350 above and accompanying text. In retrospect, Jackson explained that he did not address international law in his opinion because the State Department viewed international law as "its special province." Jackson, Reminiscences, note 45 above, at 906 . In his unpublished article, Jackson further explained: "From the beginning, Roosevelt, Hull, Welles, Stimson, and I had been in agreement that Hitler's war was one of naked aggression, that by contemporary international law, it was an illegal one, and that other powers [e.g., the United States] were under no obligation to remain indifferent." Jackson, Final Draft, note 6 above, at 103. See also Jackson Reminiscences, note 45 above, at 406 . Whether Hull and Welles actually agreed from the beginning is not entirely clear. See notes $70-73 \& 101$ above and accompanying text. 
The critics also vigorously attacked Jackson's interpretations of the various relevant statutes. There were many strong counter arguments to Jackson's treatment of the Espionage Act, ${ }^{555}$ but the fact remained that at the end of the day, the statute contained a classic ambiguity. ${ }^{556}$ In another context, Jackson explained that

The Attorney General is the attorney for the Administration. I don't think he should act as judge and foreclose the Administration from making reasonable contentions. I would do the same thing with the Administration as with a private client. I would give it the benefit of a reasonable doubt as to the law. I would tell my client what his chances were, what his risk was, and support him as best as I could. That is what I did with the Administration. ${ }^{557}$

Dean Acheson took this same position in specific defense of his letter to the Times. 558

The critics also assailed Jackson's powerful interpretation of the Walsh Amendment, but their basic objection was simply that Congress "hardly contemplated such a construction." ${ }^{559}$ Of course, this

Jackson wrote his Havana speech with the aid of Hersch Lauterpacht and Willard Cowles. See Jackson, Attorney Generalship at 23 (Lauterpacht), note 468 above; Edwin Borchard to Philip Jessup, 13 October 1941, Philip Jessup Papers, Box A4, Library of Congress, Washington, DC. Edwin Borchard almost immediately savaged the Havana speech. Edwin Borchard, "War, Neutrality and Non-Belligerency," American Journal of International Law 35 (1941): 618 . Jackson, who by this time was on the Supreme Court, was incensed and began writing a comprehensive reply to Borchard. He was assisted by Lauterpacht and Cowles, and the drafts and correspondence are in the Robert Jackson Papers, Box 29, Folder 6 . Ultimately Jackson wisely decided not to engage in a public dispute with Borchard. Perhaps Jackson was content to rely upon Quincy Wright's spirited reply to Borchard. Quincy Wright, "Permissive Sanctions against Aggression,"American Journal of International Law 36 (1942): 103. Jackson told Cowles, "as we move farther away from the controversy it loses a great deal of its significance as a controversy." Robert $\mathrm{H}$. Jackson to Willard B. Cowles, Nov. 13, 1942, Robert Jackson Papers, Box 11, Cowles Folder, Library of Congress, Washington, DC.

555 Briggs, "Neglected Aspects," note 53 above; Borchard, "Attorney General," note 53 above; 86 Cong. Rec 11827-828 (9 September 1940) (Mr. Lewis). See also Preuss "Concepts of Neutrality," note 85 above, at 97.

556 See note 347 above and accompanying text.

${ }^{557}$ Gerhart, America's Advocate, note 13 above, at 221-22 (quoting Jackson).

558 "[C]lose questions of interpretation have always been and should be resolved in consonance with the vital public interests of the sovereign whose laws are construed." McLellan, Dean Acheson, note 19 above, at 42 (quoting Acheson).

559 Borchard, "Attorney General," note 53 above, at 693; Briggs, "Neglected Aspects," note 53 above, at 575; 86 Cong. Rec. 11695 (9 September 1940) (Mr. Horton). The most thoughtful Congressional critic did not even address the Walsh Amendment. 86 Cong. Rec. 11827- 829 (9 September 1940) (Mr. Lewis). 
was precisely Jackson's point. Congress was not contemplating an exchange of destroyers for bases when it enacted the Walsh Amendment. Using the precise words of the statute and indisputable public policy, Jackson crafted an interpretation that indisputably furthered national security.

Jackson's critics strangely ignored or downplayed his egregious misconstruction of Section 492. Professor Herbert Briggs of Cornell, who wrote the most thoughtful and comprehensive criticism, ${ }^{560}$ did not even mention Section 492. ${ }^{561}$ Professor Edwin Borchard of Yale limited himself to a mild, virtually unadorned statement that Jackson's reading "seems a little unusual." 562 A few other critics briefly asserted without elaboration that Jackson's construction was wrong. ${ }^{563}$ Professor Edward Corwin hysterically and erroneously shrieked, "[n]o such dangerous opinion was ever before penned by an Attorney General of the United States." 564 Corwin, however, skimmed over

560 Briggs, "Neglected Aspects," note 53 above. Professor Phillip Jessup to Charles C. Burlingham, 25 September 1940 ("Briggs has written an article which I understand is very good."), Charles Burlingham Papers, Harvard Law Library.

561 Briggs, "Neglected Aspects," note 53 above. Other critics also ignored Jackson's treatment of Section 492. 86 Cong. Rec. 11429 (4 September 1940) (Mr. Harness).

562 Borchard, "Attorney General," note 53 above, at 692. See also Bruff, Bad Advice, note 8 above, at 39 ("he was on thin ice"). In retrospect, Jackson condemned Borchard as having "a long record of being pro-German in many things." Jackson Reminiscences, note 45 above, at 910 . This ad hominem suggestion that Borchard was in some way pro-Nazi is unbecoming of Jackson. Among other things, Borchard was Jewish and was a firm supporter of civil rights during World War II. See Sarah Ludington, "The Dogs that Did not Bark: The Silence of the Legal Academy during World War II," Journal of Legal Education 60 (2011): 419-20 \& 431. Borchard was not "pro-German." Instead, he strongly believed in the then traditional international law principles of neutrality. See Justus Doenecke, "Edwin M. Borchard, John Bassett Moore, and Opposition to American Intervention in World War II," Journal of Libertarian Studies 6 (1982): 1.

563 Corwin, "Executive Authority," note 308 above. The most thorough criticism of Jackson's misconstruction of Section 492 came from Representative Lewis. 86 Cong. Rec. 11827 (9 September 1940).

564 Corwin, "Executive Authority," note 308 above. He continued, "why may not any and all of the Congress's specifically delegated powers be set aside . . . and the country be put on a totalitarian basis without further ado?" Ibid. Corwin based his charge on Jackson's reference to the President's constitutional powers as commander-in-chief and over foreign affairs. Accord Fellmeth, "Divorce," note 134 above, at 478-80. Jackson, however, had invoked these powers in respect of the narrow issue of the President's authority to accept the offer of a lease of base rights (see notes $468-73$ above and accompanying text) and not as a basis for ignoring an act of Congress. Corwin and Fellmeth simply misread the opinion. See Casto, "Robert Jackson," note 525 above, at 380-81. 
Jackson's treatment of Section $492 .{ }^{565}$ Jackson, Frankfurter, Cohen, and Acheson thought about replying to Corwin's charge but reached a "consensus" that no answer was necessary. ${ }^{566}$

The critics' emphasis on international law, the Walsh Amendment, and the Espionage Act are readily explainable. The Walsh Amendment was only a month old, and the President's actions could be viewed (albeit erroneously) as a direct violation of the American tradition of legislative supremacy. The Walsh Amendment also implicated the extent to which the country might become embroiled in the European War. Likewise, the Espionage Act and the then traditional principles of international law directly limited a neutral country's involvement in war. These issues directly related to the vigorous political dispute between isolationists and interventionists. Moreover, most of the critics were international law experts bent upon arguing principles of international law. In contrast, Section 492 was an obscure nineteenth-century statute involving arcane issues of federal contract law. ${ }^{567}$

\section{DENOUEMENT}

In retrospect, the dispute over Jackson's opinion was a tempest in a teapot. Most Americans supported the Destroyers Deal, and in any event, the Deal was quickly overtaken by other political events. About a half year later, Congress enacted the Lend Lease Act. ${ }^{568}$ Then came Pearl Harbor. As for the destroyers, themselves, the Navy immediately began sending them to Canada where the Royal Navy took possession. ${ }^{569}$ The British quickly put them to work. Because the Germans never mounted an invasion of Great Britain, the

\footnotetext{
565 He simply stated without elaboration that "the transaction was obviously not a sale in the sense of Section 492, the 'manner' of which the President was authorized to alter." Corwin, "Executive Authority," note 308 above.

${ }^{566}$ Benjamin V. Cohen to Charles C. Burlingham, 15 October 1940, Charles Burlingham Papers, Harvard Law Library.

567 People were more interested in international law and American neutrality than "the technicalities of the United States Code." Langer \& Gleason, note 7 above, at 773 .

568 Lend-Lease Act, Pub.L. 77-11, 77th Cong., 1st sess., ch. 11, 55 Stat. 31.

569 The first flotilla of destroyers arrived in Britain on September 28. James MacDonald, "Old U.S. Warships Reach British Port," New York Times, 29 September 1940.
} 
destroyers turned out to be less than vital to Britain's survival. Nevertheless, they were of some use. ${ }^{570}$ Britain's survival and America's entry into the war significantly diminished the value to the United States of the bases. As a practical matter, the British Isles remained the front line of defense in the naval war of the North Atlantic, and the bases were in the relative back waters of the struggle. In an August speech to Parliament, Winston Churchill ecstatically explained, that the Destroyer-for-Bases Deal "means that two great organizations of the English-speaking democracies ... will have to be somewhat mixed up together in some of their affairs for mutual and general advantage." 571 He assured Parliament that he had no "misgivings" about the deal, and

I could not stop [the process] if I wished; no one can stop it. Like the Mississippi, it just keeps rolling along. Let it roll. Let it roll on full flood, inexorable, irresistible, benignant, to broader lands and better days. ${ }^{572}$

The United States was no longer neutral.

\section{CONCLUDING THOUGHTS}

Robert Jackson played the leading role in providing legal advice to the president regarding the Destroyers-for-Bases Deal, and his unpublished article makes him one of the leading legal historians of the Deal. He is greatly admired and should be admired, but our admiration must be tempered by a frank recognition of the political realities confronting attorneys in government. Our admiration should

\footnotetext{
570 See Goodhart, Fifty Ships, note 7 above, ch. XIV. HMS Campbelltown/USS Buchanan had a short but famous career in the Royal Navy. See James G. Dorrian, Saint-Nazaire: Operation Chariot - 1942 (Barnsley: Pen \& Sword Military, 2006). In 1942 , the British disguised her as a German destroyer, loaded her with $4 \frac{1}{2}$ tons of high explosives, sailed her into St. Nazaire, rammed the vast dry dock, and demolished the facilities. The St. Nazaire facility was the only dry dock on the Continent capable of handling the largest German battleships. For a good movie based upon the Campbelltown/Buchanan's career, see Gifthorse, 1952, Romulus Films. For a far less satisfying take on the St. Nazaire raid, see Attack on the Iron Coast, Mir isch Films, 1968.

${ }^{571}$ Winston Churchill, Speech to Parliament, 20 August 1940, in Churchill War Papers, note 1 above, 2:687, 697. Churchill was describing the lease of the bases as a spontaneous gift "without being asked or offered any inducement." Ibid., at 696. He made no mention of the destroyers.

572 Ibid. After the speech, "he sang Ole Man River in the car all the way back." Gilbert, Finest Hour, note 4 above, at 743 (quoting Churchill's private secretary).
} 
be based upon political reality and not upon fairy-tale slogans about the legal profession. With this in mind, Jackson's dual roles as an historian and as an attorney warrant further thought.

\section{A. Remembrances of Things Past}

From the beginning of recorded history, historians have written their stories from particular points of view that inevitably influence their analyses. A particular subset of this pervasive fact of life involves historians who were themselves significant participants in the events that they chronicle. When Thucydides penned his History of the Peloponnesian War, the role that he had personally played in that epic inevitably influenced his analysis. ${ }^{573}$ Similarly, Jackson was a significant participant in the events that he related, and his account has significant discrepancies and lacunae. This fact of life does not diminish the value of his contributions. ${ }^{574} \mathrm{~A}$ careful consideration of the apparent errors in his account enables us to understand more fully the events that he described.

Jackson's account of the three days beginning with August 13 glosses over a legal nightmare. On the basis of a specific legal analysis, he informally advised the president on August 13 that the president had unilateral authority to close the deal. Roosevelt acted that same day in reliance upon the advice. But three days later, Admiral Stark refused to make a finding of fact essential to Jackson's original legal advice. The president then exerted significant pressure on Jackson and Stark to resolve the problem, and eventually Jackson blinked. He came up with an alternative opinion that did not comport with the standards of traditional legal analysis.

\footnotetext{
${ }^{573}$ See Donald Kagan, Thucydides: The Reinvention of History (New York: Viking, 2009), in which the author splendidly analyzes the distortions, conflations, and lacunae in Thucydides's equally splendid History. Thucydides was a prominent supporter of Pericles, held important military command during the war, and following his defeat in an important campaign, was banished from Athens. Ibid., at 7-8, 7576, 96-97. Professor Kagan's purpose was not to trash Thucydides, whom he obviously admires. Rather, the book is an extended cautionary tale on the perils of relying upon eyewitness, historical accounts.

574 Jackson understood this unavoidable problem. In a preliminary draft of his Destroyer Article, he noted, "[c]ontemporaries can not offer unbiased judgments but sometimes only contemporaries can contribute information vital to the unbiased judgment which later years will try to reàch." Jackson, Draft 1-16, note 6 above.
} 
An interesting flaw in Jackson's story relates to his timeline regarding his advice to the president and the president's decision to transfer the destroyers without obtaining formal congressional approval. In Jackson's view, the president did not decide to transfer until after Jackson concluded sometime on or after August 15 that the president had unilateral authority. Other sources, however, establish that the president reached his decision on August 13. The discrepancy is interesting because it relates to Jackson's exercise of independent professional judgment in assessing the president's power.

When the Deal first became public knowledge, some assumed that the president ordered Jackson to give an opinion supporting the Deal and that Jackson simply followed the president's order. ${ }^{575}$ When he began writing his essay on the Deal, he obviously wished to rebut this charge. He specifically noted that he had in mind "those who imagine that the President decided to go it on his own and ordered the Attorney General to turn out a sustaining opinion." ${ }^{\prime 276}$ To rebut the charge against him, Jackson created a timeline in which his final analysis came first, and the president's decision came later. ${ }^{577}$

\footnotetext{
575 See, e.g., 86 Cong. Rec. 11, 829 (9 September 1940) (Mr. Curtis). See also Fellmeth "Divorce," note 134 above, at 510-11; Moss, Nineteen Weeks, note 7 above, at 296. William Castle, former Under Secretary of State, under President Hoover, wrote in private, "according to friends of mine in the Department of Justice, ... the President ordered Jackson to write the opinion and he had to make the best of a bad matter." William Castle to Edwin Borchard, 6 November 1940, Edwin Borchard Papers, Box 2-30, Yale University. In 1968, Luther Huston, a DOJ Director of Information in the 1960s, made the wildly inaccurate claim that the president negotiated the destroyers deal and actually transferred some of the destroyers before asking for Jackson's opinion. Luthor Huston, "History of the Office of the Attorney General," at 12, in Roles of the Attorney General of the United States (Washington, DC: American Enterprise Institute, 1968). At least one scholar has been duped by Huston's claim. Martin S. Sheffer, Presidential Power: Case Studies in the Use of the Opinions of the Attorney General (New York: Univ. Press of America, 1991), 36-37. The first destroyers did not arrive in Great Britain until Sept. 28, 1940. See note 569 , above.

576 Jackson, Final Draft, note 6 above, at 93 . He complained to a friend about a "studied campaign" by "isolationists and anti-British writers". to discredit President Roosevelt. "One of the chief points of misrepresentation," he continued, "has been the Destroyer transaction." Robert Jackson to Sir Norman Birkett, Feb. 19, 1953, Robert Jackson Papers, Box 9, Folder "Bi-Bl," Library of Congress, Washington, DC. He planned to publish an article to set the record straight. Ibid.

577 Jackson, Final Draft, note 6 above, at 87-99.
} 
On August 2, the president and the cabinet reached a unanimous agreement that the destroyers should be transferred to the British. They also engaged in a serious and wide-ranging discussion of trading the destroyers for bases. As soon as Churchill received word of a possible trade, he immediately assented. He insisted, however, "[i]t is understood that this will enable us to secure destroyers ... at once. ... It is, as you say, vital to settle quickly. Now is the time when we want the destroyers." ${ }^{278}$

There was a general consensus at the August 2 Cabinet meeting that Congressional approval would be necessary to accomplish a destroyers-for-bases trade. The next day, the president gave the British Ambassador disquieting news that obtaining legislation would take at least three weeks to a month. ${ }^{579}$ Then the Ambassador had a very discouraging meeting with Secretary Hull, who reminded the Ambassador that the proposed trade was unlawful under the Espionage Act and the Walsh Amendment. Therefore, authorizing legislation would be necessary and "such matters moved slowly." ${ }^{80}$ Hull proposed putting the deal on the back burner until after the November elections. ${ }^{581}$

Jackson, himself, later remembered that, "the fact was that the people realized that Congress would debate the thing for six or eight months before they would ever come to a policy." 582 He continued, "if the [destroyer deal] were submitted to Congress, [the president] knew, and everyone else knew, that there was a very strong isolationist element in Congress that would filibuster, oppose and resist any aid to Great Britain." 583 In a preliminary draft of his destroyer article, he explained that any effort to obtain formal legislative

578 Winston S. Churchill to Lord Lothian, 3 August 1940, Churchill War Papers, note 1 above, 2:607.

579 Lord Lothian to the Foreign Office, 4 August 1940, discussed in Shogan, Hard Bargain, note 7 above, at 194 . The president was also worried by the prospect of a Senate filibuster. He proposed the trade as "molasses" that would sweeten the deal for the Congress. Ibid. (quoting Lothian).

580 Memorandum of Conversation, 5 August 1940, at 3, Cordell Hull Papers, Box 58 , Library of Congress, Washington, DC.

581 Lord Lothian to Foreign Office, 5 August 1940, discussed in Leutze, Bargaining, note 7 above, at 109.

582 Jackson Reminiscence, note 45 above, at 877 .

583 Ibid., at 891 . Senate Majority Leader Alben Barkley advised the President that isolationists would filibuster destroyer legislation. Joseph Alsop \& Robert Kintner, "The Capital Parade," Charleston Daily Mail, 6 September 1940. 
approval would be "exposed to the obstructive tactics of Republicans who came from constituencies so strongly isolationist that it would be advantageous, or from those so heavily Republican that it would be safe to oppose it. These, added to a formidable opposition from the President's own party [e.g., Senator Walsh ${ }^{584}$ and Senators Wheeler, La Follette, and Bone ${ }^{585}$ ] made certain that long delay was the best that could be expected from submission of the proposal to Congress. Meanwhile, evidence accumulated that it was politically safe to proceed by Executive Agreement." 586

As we have seen, the legislative logjam prompted Justice Frankfurter to arrange for Cohen and Acheson to reconsider the issue of unilateral executive authority, ${ }^{587}$ and their letter to the Times spurred Jackson to action. In Jackson's final draft of his essay, however, he downplays the Cohen-Acheson letter's influence. Jackson relates that the "President saw the letter and asked what I thought of it, but gave no indication that he desired any particular answer." 588 Judge Townsend gave his analysis of the Times letter to Jackson on August 13, ${ }^{589}$ and "[o]f course, I [Jackson] told the president of this development." 590 Then Jackson's account skips to August 15 and notes that on that day Green Hackworth and Judge Townsend prepared a summary of their conclusions that the president had unilateral authority to accomplish the trade. ${ }^{591}$

The preliminary drafts of Jackson's essay tell a subtly and significantly different story. In relying upon preliminary drafts, a distinction should be drawn between a draft's legal analysis and its statements of fact. For example, in studying Jackson's judicial opinion in Steel Seizure, his preliminary drafts may show an evolution of his thinking. ${ }^{592}$ His official opinion, however, records what he finally concluded

\footnotetext{
584 See notes 176-91 above and accompanying text.

585 See note 48 above and accompanying text.

586 Jackson, Draft 1-16, note 6 above. See also Jackson, Draft 1-23b, at 21, note 6 above. Accord, John McCloy to Dean Acheson, 13 September 1940, Dean Acheson Papers, Box 21, Yale University.

587 See note 381 above and accompanying text.

588 Jackson, Final Draft, note 6 above, at 95.

${ }^{589}$ See note 446 above and accompanying text

590 Jackson, Final Draft, note 6 above, at 96

591 lbid., at 96 . See also note 453 above and accompanying text.

592 See Adam White, "Justice Jackson's Draft Opinions in the Steel Seizure Case," Albany Law Review 69 (2006): 1107.
} 
that the law should be. In contrast, statements of fact in preliminary drafts are different. There are many reasons why an author might delete or alter statements of fact that appeared in a preliminary draft. An author might discover or decide that a preliminary statement of fact is inaccurate. There are, however, other reasons that might lead to a deletion or alteration of preliminary factual statements. An author might drop a factually correct statement that provides unnecessary detail or perhaps might be viewed as controversial. ${ }^{593}$ In addition, an author might delete or massage preliminary factual statements that do not support the author's thesis. ${ }^{594}$ Jackson spent most of his adult life as an advocate, and we may reasonably assume that he consciously or subconsciously crafted his destroyer essay as an advocate's brief.

The final draft depicts a president who appears neutral toward the Times letter, and who simply asked what Jackson thought of the letter. But when Jackson began writing his essay, he remembered that the "President indicated an interest in the question of his power to act independently." 595 A contemporary syndicated newspaper column bluntly stated that the president had "hurriedly called Attorney General Jackson back from vacation and asked him to study the matter carefully." 596 In response, Jackson "told him the

593 For example, in one of Jackson's preliminary drafts, he described in vivid detail the social and political considerations that led some to oppose aid to Great Britain but eventually decided to strike this passage. See note 17, above, and accompanying text.

${ }^{594}$ For example, Jackson speculated in his Reminiscences that at the August 2 cabinet meeting, it was not clear whether the need to seek congressional approval was dictated by politics or by the law. See note 606 , below, and accompanying text. He stated and restated this same idea in multiple drafts of his article but eventually deleted it. See note 615 below.

595 Jackson, Draft 1-16, at 26, note 6 above. In this same draft, Jackson surmised that the President "would not be likely to concern himself greatly with the question of power [to accomplish the transaction] until he had made up his mind that he probably would resort to it." Ibid., at 19. See also Jackson, Draft 1-24, at 29, note 6 above: ("he asked me to investigate the subject of his powers to effectuate such an exchange."). In his oral history, Jackson said, "Sometime before that (i.e., Aug. 13] the President had discussed with me the legal situation as to whether he had authority to make a disposition of the destroyers without further authorization from Congress." Jackson Reminiscences, note 45 above, at 892.

${ }^{596}$ Drew Plouson \& Robert Allen, "Washington Merry-Go-Round," Galveston Daily News, 7 September 1940. Dean Acheson reports that when the Cohen/Acheson letter appeared in the Times, Jackson was on vacation in Pennsylvania and that he "cut short his vacation" and returned to Washington. Acheson, Morning, note 20 , above, at 223. 
subject was being studied and that I would let him know the results, but that the Cohen opinion and the Times letter each made on its face a strong case." 597

Two days later on August 13, Judge Townsend finished his analysis of the Cohen-Acheson letter. ${ }^{598}$ In Jackson's final draft, he notes that Judge Townsend "concluded that there was a basis in existing statutes probably sufficient for Presidential disposition of the overage destroyers." 599 In neutral terms, Jackson then commented: "of course, I told the President of this development." 600

We cannot know for certain what Jackson told the president on August 13 , but he likely gave the president an informal green light to transfer the destroyers without formal Congressional approval. Two days earlier, he had told Roosevelt that Cohen's memorandum and the Times letter "each made on its face a strong case." 601 In response, the president specifically asked him to explore the issue of "power to act independently" 602 of Congress. Then on August 13, Jackson reported on his exploration of the topic. Given this course of events, it is rationally inconceivable that the president did not ask Jackson whether there was unilateral executive authority to accomplish the trade. Jackson, himself, wrote in a rough draft that he "advised the president of Judge Townsend's conclusion, which seemed to be sound." 603

Later that day, the president met secretly ${ }^{604}$ with Secretaries Morgenthau, Stimson, Knox, and Welles for a "momentous conference."605

597 Jackson, Draft 1-16, note 6 above, at 26. The final draft simply deletes most of these factual statements without directly contradicting them.

598 See note 446 above and accompanying text.

599 Jackson, Final Draft, note 6 above, at 96 .

$600 \mathrm{lbid}$., at 96

601 See note 597 above and accompanying text.

602 See note 595 above and accompanying text.

603 Jackson, Draft 1-20, at 30-31, note 6 above. Jackson continued, the President "told me that he might want a formal opinion on the subject." Ibid., at 31 . In his oral history, Jackson relates that, "[s]ometime before [August 13] the President had discussed with me the legal situation as to whether he had authority to make a disposition of these destroyers without further authorization from Congress." Jackson Reminiscences, note 45 above, at 892.

604 "[T]he word had come to us to go in by the Treasury entrance to the White House so as not to attract the attention of the reporters." Stimson Diary, 13 August 1940, note 3 above.

${ }^{605}$ Ibid; Stimson \& Bundy, On Active Service, note 85 above, 356-57. Secretary Hull did not attend because he was on vacation. See Hull, Memoirs, note 78 above, 1:833-34. In Hull's absence, Welles was serving as Acting Secretary of State. 
The President and this rump cabinet engaged in a far ranging discussion of the destroyers transaction, and the president personally drafted the offer of destroyers for seven specific bases and assurances from the British regarding the Royal Navy. ${ }^{606}$ Later that night, Roosevelt conferred with the British Ambassador, ${ }^{607}$ and the State Department cabled the offer to London. ${ }^{608}$

The President told Churchill, "it may be possible to furnish the British Government as immediate assistance at least 50 destroyers [and] the motor torpedo boats." 609 The President's offer of "immediate assistance" indicates that he had decided, based upon Jackson's advice earlier that day that there was unilateral executive power to conclude the deal. There was general agreement at the time that referring the matter to Congress for formal legislation would delay the deal by weeks, months, or perhaps permanently. The day before Roosevelt made his offer of "immediate assistance," Senator Pepper, a strong supporter of aid to the British, told Secretary Stimson that "there was no chance of getting, in his opinion, the Congress to repeal the provision as to the sale of the destroyers."610

Jackson emphatically denies that the President decided on August 13 to bypass Congress: "I am sure the decision was not reached earlier than August 15."611 He essentially elides his informal advice to the President on August 13 with a bland, neutral statement that "I told the President of [Judge Townsend's conclusions]." ${ }^{612}$ To repeat: given the facts that the President had specifically asked Jackson to brief the issue two days earlier, that Jackson agreed with Townsend's analysis, and that Jackson tried to use the analysis two or three days later, it beggars the imagination to believe that the Pres-

\footnotetext{
${ }^{606}$ Long hand note, 13 August 1940, F.D.R., His Personal Letters, note 136 above, 2:1052. See Stimson Diary, 13 August 1940, note 3 above.

607 Usher Books, 13 August 1940, FDR Library, Hyde Park, NY ("9:31 pm Lothian to 10:41"). Unfortunately, the Usher Books do not approach being a complete record of the president's daily visitors.

${ }^{608}$ Roosevelt to Churchill, 13 August 1940, 6 p.m., Churchill \& Roosevelt, note 455 above, at 1:58-59.

609 /bid., at 58-59 (emphasis added).

610 Stimson Diary, 12 August 1940, note 3 above.

611 Jackson, Final Draft, note 6 above, at 91.

612 Ibid., at 96.
} 
ident did not ask for Jackson's opinion and that Jackson did not informally give it on August 13.

Jackson carefully explains in the final draft of his unpublished essay that the President's August 13 offer of "immediate assistance" was not really an offer. In a lawyerly analysis, he treats the offer as a legal document to be construed by its plain meaning and without regard to its context. Jackson noted that the offer stated that the assistance "would only be furnished if the American people and the Congress frankly recognized that in return therefore the national defense and security of the United States would be enhanced." ${ }^{\prime 13}$ Jackson argued that the reference to Congress meant that the President was still planning to seek legislation. His lawyerly analysis fits the words of the offer but makes no sense given the context of Britain's immediate, pressing needs and the President's offer of immediate assistance. Jackson later remembered that legislation would take "six or eight months." ${ }^{14}$ Why would the president waste his and Churchill's time with this offer of immediate assistance if the president knew that the quest for legislation was at best fraught with significant delay and at worst in Senator Pepper's words, had "no chance?"

Jackson, himself, provides an alternative explanation of the offer's reference to Congress. He stated in his oral history that in early August, "[w]hether [the president] had meant to say that it would legally and constitutionally require the approval of Congress, or that politically it would require the approval of Congress, I don't know." ${ }^{15}$

613 Jackson, Final Draft, note 6 above, at 91 (quoting the offer).

${ }^{614}$ See note 582 above and accompanying text.

615 Jackson Reminiscences, at 891 , note 45 , above. In early drafts of his article, Jackson stated the distinction between political and legal necessity more emphatically. He insisted that at the August 2 cabinet meeting, the "necessity for legislation on which all of the Cabinet agreed was political rather than legal. The Attorney General had at that time been asked for no opinion on such necessity. A number of members of the Cabinet were not lawyers and not likely to be expressing a legal opinion." Jackson, Draft 1-16, at 16, note 6 above. In the immediately preceding page of this draft, Jackson penned in the margin: "Necessity pol-not legal. No opinion. Cohen to contrary doubts - not lawyers." Ibid., at 15. The same language appears in Jackson, Draft 1-19, at 16, note 6 above. See also Jackson, Draft 1-20, at 15-16, note 6 above; Jackson, Draft 1-22, at 13-14, note 6 above. 
In his final draft, Jackson deleted his initial recollections that it was not clear at the August 2 cabinet meeting whether the need for legislation "was political rather than legal." One wonders whether he suddenly remembered that the president believed that formal legislation was necessary or that he deleted his earlier remembrances because they were inconsistent with his thesis that the president's August 13 offer of "immediate assistance" was contingent on formal legislation. If the president was thinking of a political consultation with members of Congress, there is no conflict between his offer of "immediate" assistance and the condition that "Congress [must] frankly recognize" the deal's value. ${ }^{616}$

In fact, the President sought and obtained tacit approval from Wendell Willkie, the Republican candidate for president and Charles McNary, the Republican candidate for vice president and Senate minority leader. ${ }^{617} \mathrm{McNary}$ confided that he would have difficulty voting to approve the Deal, but he "would make no objection to the transfer if plausible grounds were found for proceeding without Senate action." ${ }^{18}$ Other Republicans and isolationists also winked

516 Jackson also noted that on August 14 and 17, Secretaries Stimson and Knox were talking about the need to go to Congress. Jackson, Final Draft, note 6 above, at 92 . Because both Stimson and Knox were at the secret August 13 meeting when the president announced that he would transfer the destroyers without formal legislation (see note 613 below and accompanying text), they must have had in mind a political consultation. Stimson's words are consistent with this distinction. See Stimson Diary, 14 August 1940, note 3 above. Moreover, at the August 16 cabinet meeting, the president formally announced "that the Attorney General had finally decided that [legislation] would not be necessary." Ibid. (Aug. 16, 1940 entry). Jackson tells us that the next day "Secretary Knox was publicly declaring that the question was one for Congress to decide." Jackson, Final Draft, note 6 above, at 92, relying upon Langer \& Gleason, note 7 above, at 759 n. 47 . Langer and Gleason relied upon a New York Times story that did not quote Knox but did say, "The transfer of fifty ... destroyers ... was declared today by Secretary Knox to be a question for Congress to answer, not the Navy Department." New York Times, 18 August 1940 (dateline 17 August). Perhaps the reporters misreported what Knox literally said. Certainly this report is contrary to what the president said at the August 13 meeting and at the August 16 cabinet meeting. Perhaps Knox was speaking under the influence of CNO's flat refusal the day before to make the necessary finding under the Walsh Amendment. Finally, perhaps Knox was being tricky. He said that the Navy Department could not on its own effect the transfer. He literally was silent in regard to the president's authority.

617 See notes 435-38 above and accompanying text.

618 Benjamin Cohen, "Presidential Responsibility and American Democracy," in Benjamin Cohen et al., The Prospect for Presdiential-Congressional Government (Berkeley: Institute of Governmental Studies, Univ. of California, 1977), 19 \& 27. 
their tacit approval so long as the matter did not come to a formal vote. ${ }^{619}$ Roosevelt also lobbied members of his own party in Congress. ${ }^{620}$ Finally, the president took Representative Vinson and Senator Walsh, the chairmen of the House and Senate naval affairs committees, on a yacht trip to argue his case. Vinson approved the trade but Walsh remained adamantly opposed. . $^{621}$

By far the best evidence of when the president decided to bypass Congress is what the president, himself, said at the August 13 secret meeting when he decided to offer the British immediate assistance:

The President asked whether he should conclude the deal with the English first and tell Congress afterward or tell Congress first. I [Morgenthau] said I thought he ought to tell Congress first, but the undercurrent of those present seemed to be he should do it first and tell Congress afterward. ${ }^{622}$

619 Nationally syndicated columnists Drew Pearson and Robert Allen reported that the President indirectly "sounded out congressional leaders, including republicans and isolationists [who] were unanimous that the president should arrange the deal himself, and not ask the approval of Congress." See, e.g., "The Daily Washington Merry-Go-Round," Galveston Daily News, 7 September 1940; Nevada State Journal, 7 September 1940. Accord Bruce Catton, "Origin of the Destroyer Deal," Charleston (WV) Daily Mail, 8 September 1940. Pearson and Allen reported that "[e]ven Sen. Wheeler, vigorous isolationist, advised along these lines." Galveston Daily News, 7 September 1940. Roosevelt told the Canadian Prime Minister that senators and representatives "had said to him: 'For God's sake don't put this question to Congress or you will have a few month's debate on it. Find some other way to deal with the matter!'” Mackenzie King Report, note 246 above, at 132.

620 For example, Roosevelt spoke with Senators Pepper and Lee on August 15, and later that day, Lee urged on the Senate floor that the President had unilateral authority under existing law to transfer the destroyers. New York Times, 16 August 1940 (dateline 15 August); 86 Cong. Rec. 10402-10 (15 August 1940) (recording spirited debate). See also, "The Day in Washington," New York Times, 16 August 1940. As early as August 12, Senators Pepper, Lee, and Krieg were publicly supporting sending the destroyers to Britain. New York Times, 13 August 1940 (dateline 12 August).

621 James F. Cook, Carl Vinson (Macon, GA: Mercer Univ. Press, 2004), 156. See also "U.S. Negotiating for British bases, plan with Canada," New York Times, 17 August 1940 (Vinson: bases "essential for the defense of the Panama Canal."); David Walsh to Franklin Roosevelt, 19 August 1940, quoted and discussed in Shogan, Hard Bargain, note 7 above, at 220; David Walsh to Raymond Clapper (29 Aug. 1940), Raymond Clapper Papers, Box 243, Library of Congress.

622 Morgenthau Presidential Diary, 14 August 1940, note 262 above, Bk 3, p. 635. Professor Blum suggests that this meeting took place on August 14. John Morton Blum, Roosevelt and Morgenthau (Boston: Houghton Mifflin, 1940), 334. Although Morgenthau wrote the entry on August 14, he begins his discussion of the meeting with the words, "At the meeting yesterday (August 13th)." Morgenthau Presidential Diary, 14 August 1940, note 262 above, Bk 3, p. 634. 
Clearly Roosevelt had reached his decision to go it alone without formal legislation. He was not thinking about seeking legislation first. He was thinking about possibly telling the Congress first. Presumably he relied upon the informal advice that Jackson gave him earlier that day. To be fair, Jackson did not attend the August 13 secret meeting.

Whether Jackson gave the president a green light on August 13 or a few days later turns out to be significant due to the dramatic turn of events on or shortly before August 16. Again, there is a significant lacuna in Jackson's story of that day. He had originally decided to premise the president's unilateral authority on Sections 491 and 492 , which gave the president broad authority over the sale of vessels struck from the Navy Register. ${ }^{623}$ On August 16, however, Chief of Naval Operations Stark formally refused to strike the destroyers from the Register. ${ }^{624}$ Jackson describes Stark's flat refusal in the following passage:

At the Department of Justice, we . . . were joined by Admiral Stark, the Chief of Naval Operations, who had opposed a sale or loan of the destroyers. His certificate was essential under our view of the law, and he still was skeptical about taking the responsibility of making a certificate. ${ }^{625}$

The essential certificate that Jackson mentions relates to the Walsh Amendment ${ }^{626}$ - not Sections 491 and 492. Jackson does not mention that on that day, Admiral Stark torpedoed Jackson's original legal analysis.

\section{B. Traditional Legal Analysis vs. Political Analysis}

A few years before his untimely death, Jackson strove to distill his thoughts on the duties of an attorney-adviser in governmentin particular, the duties of the attorney general. With specific reference to the destroyer deal, he said,

I think the Attorney General has a dual position. He is the lawyer for the President. He is also, in a sense, laying down the law for the government as a judge might. I don't think he is quite as free to advocate an untenable position because it happens to be his client's position as he would be if he

\footnotetext{
${ }^{623}$ See notes $453 \& 475$ above and accompanying text.

624 See notes $476-81$ above and accompanying text.

625 Jackson, Final Draft, note 6 above, at 96.

${ }^{626}$ See note 190 above and accompanying text.
} 
were in private practice. He has a responsibility to others than the President.

$\mathrm{He}$ is the legal officer of the United States. ${ }^{627}$

Jackson's understanding that the attorney general is a servant of two masters is somewhat inconsistent with today's principles of professional responsibility. Today, the attorney general's client is viewed in theory as being the United States and not the president. ${ }^{628}$ Jackson's description of the office may have been influenced by the fact that in 1940 there was no White House legal counsel. ${ }^{629}$ Notwithstanding this technical distinction, perhaps Jackson's description of his office as a dual position is more accurate in terms of actual practice than the theory presented in the ABA Model Rules. More than one recent attorney general appears to have embraced a dual analysis similar to Jackson's. ${ }^{630}$

627 Jackson Reminiscences, note 45 above, at 911 . For a similar analysis, see Baker, Conflicting Loyalties, note 8, above, at 153-54 (quoting former Attorney General Griffin Bell).

${ }^{628}$ See ABA Model Rules of Professional Conduct, Rule 1.13; ibid. comment 9 ("this Rule applies to governmental organizations"). There was no comparable Canon during Jackson's time. Statements by recent Attorneys General tend to follow the ABA approach. For example, current Attorney General Eric Holder elevated former Attorney General Richardson's portrait to a place of prominence because "Elliott Richardson is a constant reminder to me about the importance of independence for the Justice Department from the presidency, and [a reminder] to be an independent player in the executive branch." www.foxnews.com/politics/2009/ $\underline{03 / 25}$. Attorney General Michael Mukasey remarked at his installation ceremony, "We do law, but the result is justice. And that is why our ultimate client - the people of this country-can and do rest secure in the knowledge that our unswerving allegiance is to the law and the Constitution." Prepared Remarks of Attorney General Michael B. Mukasey at His Installation Ceremony, 14 November 2007. The President's unique status as the constitutionally selected representative of the American people significantly complicates the relevance of the ABA theory to relations between attorneys and the President.

629 Before creating the post of White House Legal Counsel, President Roosevelt consulted with Jackson, who was then on the Supreme Court. Justice Jackson strongly advised against the idea. Jackson believed that the Attorney General should be the President's "always-on-hand adviser in matters of law." Jackson Memoir of Roosevelt (ca. 1953), reprinted in That Man, note 6 above, at 64-65.

${ }^{630}$ Attorney General Alberto Gonzales said on his installation, "Undeniably, the Attorney General is a member of the President's cabinet, a part of his team. But the Attorney General represents also the American people, and his first allegiance must always be to the Constitution of the United States." Remarks of Attorney General Alberto R. Gonzales installation as the Eightieth Attorney General of the United States, 14 February 2005. See also note 627 above (Griffin Bell). In retrospect, it is interesting that Gonzales affirmed his allegiance to the Constitution but made no mention of the laws of the United States. 
Jackson's actions in the summer of 1940 indicate that his thumbnail sketch of the attorney general's dual responsibilities to the president and the law cannot be taken at face value. When Jackson viewed the summer of 1940 in retrospect, he denied "that the President decided to go it on his own and ordered the Attorney General to turn out a sustaining opinion." ${ }^{311}$ Similarly, he insisted, "I never had the feeling that I had to shape my opinions to what [the president] wanted." ${ }^{632}$ Other passages from Jackson's remembrances seem at odds with his insistence regarding the president. Although President Roosevelt was a lawyer, he was-in Jackson's words - "a strong skeptic of legal reasoning." ${ }^{633}$ Moreover, "[ $t$ ] he President had a tendency to think in terms of right and wrong, instead of terms of legal and illegal. Because he thought that his motives were always good for the things that he wanted to do, he found difficulty in thinking that there could be legal limitations on them." ${ }^{634}$ In short, Jackson portrays a president who would be highly skeptical of legal reasoning that did not facilitate the implementation of the president's policy.

Other sophisticated insiders have been quite frank in describing President Roosevelt's attitude toward legal advice. After a lifetime of reflection, Acheson wrote that in the gold-purchase controversy, "the President ... lost patience with my objections and told the Attorney General to rule (and what to rule) on the legal question." ${ }^{635}$ Similarly, when Acting Attorney General Biddle ruled that the Army could release surplus munitions to the British, Treasury Secretary Morgenthau told his staff in private that "[Biddle] has got to do that. The President wants it." ${ }^{636}$ Of course, Roosevelt's directions did not

631 Jackson, Final Draft, note 6 above, at 93.

632 Jackson Reminiscences, note 45 above, at 918 quoted in Kurland, "Jackson" note 153 above, at 2561.

633 Jackson, Memoir of Roosevelt (ca. 1953), That Man, note 6 above, at 59.

${ }^{634}$ Jackson Reminiscences, That Man, note 6 above, at 74. Francis Biddle, who succeeded Jackson as Attorney General, had a similar view of Roosevelt: "[Roosevelt] was never theoretical about things. ... Nor do I think that the constitutional difficulty [of confining Japanese Americans to camps] plagued him -the Constitution has never greatly bothered any wartime President." Francis Biddle, In Brief Authority (Garden City, NY: Doubleday, 1962), 219.

${ }^{635}$ See note 424 , above and accompanying text.

${ }^{636}$ See note 123 above and accompanying text. Perhaps Biddle was more pliant than Jackson. Jesse Jones thought so. See Gerhart, America's Advocate, note 13 above, at 222 (quoting Jones). 
necessarily take the form of a blunt order. On another occasion, Morgenthau explained that Roosevelt would tell his attorney general, "If you are a good Attorney General, tell me how I can do it."637 Morgenthau continued, "They always give him a silly laugh, and go out and tell him how to do it."638

Certainly there is no doubt that attorney-advisers in government are subject to powerful political pressure. When Dean Acheson disagreed with Roosevelt on a legal issue in respect of monetary policy, he was summoned to a come-to-Jesus meeting with the president that Acheson in retrospect described as "a magnificent and intimidating experience." 639 Similarly, when General of the Army Air Corps "Hap" Arnold dragged his feet on releasing airplanes to the Allies, President Roosevelt directly threatened to remove Arnold from his position and transfer him to Guam. ${ }^{640}$ Likewise during the summer of 1940 , the president said that Navy JAG attorneys who gave unwanted opinions should be sent on "vacation," and he exiled a Treasury attorney to the "interior of a southern state." Finally, at a time when Jackson was still working on his final opinion, the president told Jackson that if the "legal difficulties [were not resolved,] a head will have to fall." 641

Consistent with the common idea that government attorneys render legal opinions in obedience to policy makers' commands, virtually every attorney who rendered an opinion relevant to the Destroyer Deal told their policy-making superior what the superior wanted to hear. Acting Attorney General Biddle green lighted the sale of Army surplus munitions, ${ }^{642}$ and Attorney General Jackson okayed the transfer of Navy Helldivers ${ }^{643}$ and the transfer of de-

637 Michael R. Beschloss, Presidential Courage: Brave Leaders and How They Changed America, 1789-1989 (New York: Simon \& Schuster, 2007), at 164-65. President Roosevelt once told Acheson much the same thing. See notes 418-19 above and accompanying text.

638 Beschloss, Presidential Courage, note 637 above, at 164-65.

${ }^{639}$ See note 98 above and accompanying text.

${ }^{640}$ See notes 91-94 above and accompanying text.

641 See note 490 above and accompanying text. See also Arthur S. Miller, "The Attorney General as the President's Lawyer," at 59 (speculating without knowledge of the head-will-roll statement, that Roosevelt might have fired Jackson if Jackson had not provided the desired legal opinion), in Roles of the Attorney General (Washington, DC: American Enterprise Institute, 1968).

${ }^{642}$ See notes 124-29 above and accompanying text.

${ }^{643}$ See notes $108 \& 181-85$ above and accompanying text. 
stroyers. ${ }^{644} \mathrm{~A}$ decade after the Destroyer Deal, Justice Frankfurter defended Jackson's destroyer opinion by quoting "that somewhat cynical but wise observation of Lord Salisbury. . . : 'What is an Attorney General for except to find justifiable legal grounds for a desirable policy." 645 To be sure, Frankfurter spoke of "justifiable legal grounds." If he simply was referring to attorneys acting in accordance with the law, one wonders why he considered this "wise observation" to be "somewhat cynical."

The Navy JAG's opinion ${ }^{646}$ and Jackson's informal opinion on the torpedo boats ${ }^{647}$ are consistent with Lord Salisbury's observation. The Navy JAG told Navy Secretary Edison exactly what Edison wanted to hear. ${ }^{648}$ Likewise, Jackson may have initially acquiesced on the torpedo-boat deal ${ }^{649}$ but changed his mind after the proposed Vinson and Walsh Amendments left the deal politically dead in the water. ${ }^{650}$ In Jackson's formal destroyer opinion, he advised that the president could not include PT/mosquito boats in the bargain for bases, but this particular advice likely stemmed from political considerations-not legal analysis. ${ }^{651}$ Among all the legal opinions by government attorneys that the present article has considered, only Dean Acheson's opinion early in the Roosevelt Administration contradicted his superior's clear extralegal policy. ${ }^{652}$ Acheson lost his

\footnotetext{
644 See notes $468-539$ above and accompanying text.

${ }^{545}$ Felix Frankfurter to James F. Byrnes, 22 September 1953, Felix Frankfurter Papers, Library of Congress, Washington, DC.

646 See notes 157-65 above and accompanying text.

647 See notes 205-18 above and accompanying text.

${ }^{648}$ See notes $89 \& 156-68$ above and accompanying text.

${ }^{649}$ See notes 151-69 above and accompanying text.

650 See notes 186-231 above and accompanying text.

651 See note 551 above and accompanying text. Some have suggested that Jackson's final PT/mosquito boat analysis indicates a willingness to limit the president's power. Arthur M. Schlesinger, Jr., The Imperial Presidency (Boston: Houghton Mifflin Co., 1973), 108; Jack Goldsmith, The Terror Presidency (New York: W.W. Norton \& Co., 2007), 198. See also Bruff, Bad Decisions, note 8 above, at 40; W. Bradley Wendel, "The Torture Memos and the Demands of Legality," Legal Ethics 12 (2009), 16. Because Jackson easily could have written a legal opinion (see notes 529-43) above, and accompanying text) justifying the transfer of the smaller boats, this suggestion is implausible.

${ }^{652}$ See notes $20 \& 416-27$ above and accompanying text.
} 
job and in later years adopted a much more pliant attitude toward using legal interpretation to facilitate policy objectives. ${ }^{653}$

In advising on the legality of proposed conduct, government attorneys almost always use the traditional method of legal analysis that they learned in law school. ${ }^{654}$ In some situations, however, they consciously abandon traditional legal analysis in favor of what might be called political judgment. Judge Townsend understood this dynamic when he advised that, "after all is said, the question of the disposition of over-age destroyers is probably more political than legal." 655 Jackson agreed and told Admiral Stark as much. ${ }^{656}$

When Jackson argued to Stark that the issue was more political than legal, he may have had in mind the concept of standing. A decade later when Jackson was thinking back to his service in the Roosevelt Administration, he remembered that standing played a role in some of his more difficult determinations of presidential power. When the President directed the commencement of construction on an airport for the nation's capital, he did so without congressional authorization or appropriation. This incident arose at about the same time that Jackson was working on his destroyer opinion. Jackson explained that the "President's action in this matter was an instance in which, although the President acts beyond the Constitution, he invades no private rights and therefore is probably not subject to injunction by a court. ... He spent some public money, but the Supreme Court long ago held that that could not be enjoined." 657

${ }^{653}$ See notes 425-31 above and accompanying text. A recalcitrant Treasury attorney may have suffered a fate worse than being fired. See notes 95-97 above and accompanying text.

654 Traditional legal analysis includes respect for precedent, respect for the words and purpose of a statute, and analysis of legislative history. In regard to statutes, traditional legal analysis involves a search for the statute's meaning or at least one of its plausible meanings. See generally Norman J. Singer \& J.D. Shambie Singer, Statutes and Statutory Construction, 7th ed. (St. Paul: Thompson/West, $2007)$.

655 See note 451 above and accompanying text.

656 See note 480 above and accompanying text.

657 Jackson, Memoir of Roosevelt (ca. 1953), That Man, note 6 above, at 48 . The ellipsis in the quote supplants the following sentence: "Here was a case where he took nobody's property." Ibid. Jackson's opinion in the Steel Seizure case is consistent with his standing analysis. In defending President Truman's seizure of portions of the steel industry, the government relied in significant part on Jackson's statement as attorney general that President Roosevelt had authority to seize the North 
The president's unilateral decision to transfer the destroyers was like his airport decision. In neither situation were private rights or property rights infringed. Indeed, Jackson began the next paragraph after his standing discussion by noting that the president "did the same thing with the destroyers in exchange for bases." ${ }^{\prime 658}$ Others also thought at the time that standing would preclude a judicial challenge to the destroyer deal. The day after the president announced the destroyer deal, the "general opinion was that the adversaries were blocked from court action [because no] direct interest of the taxpayer could be proved." 659

Three aspects of Jackson's final opinion on the Destroyers-forBases Deal illustrate the distinction and interrelationship between traditional legal analysis and political judgment. His treatment of the Walsh Amendment was a straightforward case of traditional legal analysis. The Espionage Act was somewhat more difficult because there was no clear answer either way. The President's technical authority to convey the destroyers was at the opposite end of the spectrum from the Walsh Amendment. The President clearly lacked legal authority.

Jackson's treatment of the Walsh Amendment ${ }^{660}$ was simply superb lawyering in the traditional sense. He presented an argument based upon the words of the statute, legislative history, and indisputable public policy. The purpose of the Amendment was to

American Aviation Company's plant. Jackson distinguished his North American statement in part on the fact that the North American plant "was taken over with acquiescence, amounting to all but consent, of the owners." Stee/ Seizure, 343 U.S., at $649 \mathrm{n} .17$. Perhaps Jackson believed that as a practical matter, the absence of standing might convert an otherwise justicable issue of constitutional law into a political question.

${ }^{658}$ / bid. In discussing the national airport decision, Jackson wrote, "I would certainly go a very long way to find authority to sustain that kind of an exercise of power where the congressional process seemed stalled." Ibid. Congressional gridlock would be another reason that Jackson saw a significant similarity between the national airport decision and the destroyer deal. There was a general agreement that any formal proposal in Congress would be killed or delayed for months by filibuster. See notes 580-86 \& 610 above and accompanying text.

659 Lewis Wood, "Ruling by Jackson," New York Times, 4 September 1940. See also 86 Cong. Rec. 11829 (9 September 1940) (Mr. Lewis: "I doubt very much if an injunction [against the transfer] would lie."). Accord, Bruff, Bad Advice, note 8, above, at 74 .

${ }^{660}$ See notes 514-23 above and accompanying text. 
enhance national security, ${ }^{661}$ and his interpretation, which was based on specific statutory language, authorized a deal that clearly enhanced national security. A contrary construction of the statute would have been foolhardy.

Jackson's Espionage Act analysis ${ }^{662}$ is different. Insofar as the destroyers were concerned, he used traditional legal analysis to identify an ambiguity in the statute that could be interpreted to allow the deal or to foreclose it. For Jackson, the choice was easy. Like any lawyer would, he interpreted the statute to further his client's interest. ${ }^{663}$ At the time and since that time, most attorneys-even those who supported aiding Britain-believed that Jackson's analysis was weak. ${ }^{664}$ Moreover, Jackson, himself, had to admit that it involved "hairsplitting." 665 His Espionage Act analysis adds flesh to the bones of his statement that an Attorney General is not "quite as free to advocate an untenable position because it happens to be his client's position as he would be if he were in private practice." ${ }^{166}$ Perhaps he meant that anything short of untenable is okay. Moreover, he obviously meant that in politically controversial cases, the strength of a barely tenable argument is to be gauged by a political-rather than a legal-calculus.

Jackson's Espionage Act analysis in respect of the torpedo boats also illustrates the strong influence of political concerns in cases involving otherwise traditional legal analysis. Using traditional legal analysis, he could have presented a strong legal argument that would have authorized transferring both the destroyers and the torpedo boats. Instead, he consciously made no mention of the argument and opted for a "hair-splitting" analysis. Even worse, his analysis barred the president from transferring the torpedo boats. As a matter of traditional legal analysis, his decision-making on this issue is incomprehensible-indeed, inexcusable. But as a matter of

\footnotetext{
661 See notes 522 above and accompanying text.

662 See note 524 above and accompanying text.

663 See note 557 above and accompanying text. After the war, some concluded that because the Espionage Act "was exceedingly unclear in its wording. . . , the interpretation by Mr. Jackson was probably as valid as any other." Langer \& Gleason, note 7 above, at 772 .

${ }^{664}$ See notes 540-47 above and accompanying text.

${ }^{665}$ See note 540 above and accompanying text.

${ }^{665}$ See note 627 above and accompanying text.
} 
political judgment, his decision made sense. He did not want to irritate the Congress. On the torpedo-boat issue, politics trumped legal analysis. His prior opinion had created a wide spread opinion that the president could not sell the torpedo boats to Britain. Jackson resolved the issue in favor of the Executive Branch's political agenda. He struck his best legal argument from the opinion. This was Benjamin Cohen's explanation. 667

Finally, we turn to the technical issue of the president's positive authority to convey the destroyers. When Jackson had a strong argument on the Walsh Act, he resolved the issue in the president's favor. There is no surprise here, but when he had at best, a frivolous argument on the issue of positive authority, he again resolved the issue in the president's favor. This aspect of the opinion puts even more flesh on the bones of his claim that an attorney general is not "free to advocate an untenable position." Apparently, if the political stakes are sufficiently great, even untenable arguments become acceptable.

A competent, disinterested, which is not to say uninterested, attorney could not have used traditional legal analysis to find a grant of authority to dispose of the destroyers. To be sure, there is a Humpty-Dumpty meets Jacques Derrida school of thought that denies the authority of language in statutes. ${ }^{668}$ In the author's experience, however, most attorneys believe that legal rules usually have a discernable content, and that under traditional legal analysis, some arguments may properly be rejected as simply contrary to the law and therefore invalid.

The only direct evidence that we have of the reasoning that led Jackson to drop his initial analysis and instead to rely solely upon Section 492's proviso is the opinion, itself, and his recollections a decade later. There is, however, much silence in this direct evidence.

The opinion, itself, moves from the implausible to the incredible. Jackson wrenches a proviso from its context and states that the pro-

${ }^{667}$ See notes 548-50 above and accompanying text. Cohen participated in drafting Jackson's final opinion. See note 548 above and accompanying text.

${ }^{668}$ Of course, I refer to the delightful dialog between Humpty and Alice:

"The question is," said Alice, "whether you can make words mean so many different things."

"The question is," said Humpty Dumpty, "which is to be master-that's all." Lewis Carroll, Through the Looking-Glass, and What Alice Found There (Oxford: Oxford Univ. Press, 1871), ch. 6. 
viso vests the president with affirmative unilateral power to dispose of any naval vessel. The proviso's only limitations were that the president must make the decision and the decision must be in writing. The proviso's plain meaning was to the contrary as are accepted canons of statutory interpretation. ${ }^{669}$ More significantly, Benjamin Cohen and Judge Townsend had reached the contrary conclusion on this precise issue. ${ }^{670}$ Likewise, Dean Acheson and Felix Frankfurter apparently agreed with Cohen. ${ }^{671}$ Indeed, Jackson, himself, agreed with Cohen and Townsend until CNO Stark refused to make the finding of fact crucial to the initial plan. ${ }^{672}$ Incredibly, Jackson concluded his implausible analysis with the bald ipse dixet: "I find nothing that would indicate that the Congress has tried to limit the President's plenary powers to vessels already stricken from the naval register." ${ }^{\prime 673}$

Jackson cannot have believed that there was "nothing" to the contrary. In addition to the proviso's plain meaning, canons of interpretation, and the opinions of Cohen, Townsend and others, the month-old Vinson Amendment clearly was intended to limit the president's powers. ${ }^{674}$ Yet Jackson's construction empowered the president to ignore the month-old statute as long as-in accordance with the proviso's limitations-the president recorded the decision "in writing." To repeat, Jackson cannot have believed that there was "nothing" to the contrary.

Jackson's subsequent recollections are out of focus and do not contribute much. In his essay on the destroyer deal, he glosses over the president's affirmative power to transfer the destroyers. ${ }^{675}$ Nor do his reminiscences grapple with his reliance upon Section 492's proviso. Instead, he presents a moving target. First he said that he "approved the transfer of destroyers, because they fell in the classification of obsolescent materials." 676 There was, however, no such

\footnotetext{
${ }^{669}$ See notes $496-97$ above and accompanying text.

${ }^{670}$ See notes 320-24, 451, 503-04 \& 510 above and accompanying text.

${ }^{671}$ See notes 382 \& 504-05 above and accompanying text.

${ }^{672}$ See above notes $451,475-81$ and accompanying text.

${ }^{673}$ See above note 511 and accompanying text.

${ }^{674}$ See notes 447-48 above and accompanying text.

675 He implies that he adopted the analysis outlined in Judge Townsend's memorandum, but of course he did not. See notes $475-513$ above and accompanying text.

${ }^{676}$ Jackson Reminiscences, note 45 above, at 900 .
} 
requirement in Section 492's proviso. Rather, the provision regarding the disposal of "obsolescent" materials is found in the statute used by Cohen and Acheson in their New York Times letter. ${ }^{677}$ Jackson's opinion made no mention whatsoever of the Cohen/Acheson analysis. A little later in his Reminiscences, Jackson suggested that the Walsh Amendment "implied that insofar as it didn't restrict, it left a free hand." 678 Again, his opinion did not rely upon the Walsh Amendment as a positive grant of authority to transfer the destroyers. In his recollections, Jackson never analyzed, defended, or even mentioned the portion of his opinion that used Section 492's proviso to establish the president's positive authority. He concluded his thoughts with the Delphic statement

I am frank to say that if I had had considerable more doubt about the legal proposition than I did have, or do have, I should probably have resolved it in favor of the proposition. ${ }^{679}$

At first glance, he seems to be saying that his opinion was in accordance with the law. On a close reading, however, his statement is literally to the effect that if he doubted his analysis more than he did, he still would have rendered an opinion supporting the transfer.

We cannot know for certain what led Jackson to abandon his initial analysis based upon Sections 491 and 492 and to rely solely upon 492's proviso. On balance, however, circumstantial evidence supports a conclusion that on the narrow issue of the president's power to sell the destroyers, Jackson rendered an opinion that he probably knew was contrary to the law. His opinion on this specific, narrow issue was clearly erroneous under traditional principles of statutory interpretation and especially in view of the Vinson Amendment. There is, of course, a modern attitude that anything is arguable and that no legal analysis can be in flat error. In Jackson's entire life, however, he never indicated that he subscribed to this nihilist view of the law.

There is no direct evidence of why Jackson abandoned his original analysis. There is, however, powerful circumstantial evidence to suggest the reason for the change. On August 16, Jackson did his best to convince CNO Stark to strike the destroyers from the Navy

\footnotetext{
677 See notes 407-08 above and accompanying text.

678 Jackson Reminiscences, note 45 above, at 902 .

679 Ibid., at 911-12.
} 
Register, but Stark refused. Less than a week later on August 22, Jackson had adopted his new construction of Section 492's proviso.

So what lessons may be drawn from Jackson's efforts to support his president's policies? As a preliminary matter, Jackson's initial analysis based upon Sections 491 and 492 merits brief reconsideration. As required by Section 491, his initial analysis required a factual determination that the destroyers were "unfit for further service." ${ }^{680}$ Because the destroyers were on active service, would continue to be on active service, and the British desperately needed them for active service, a contrary finding of fact would have been preposterous. In CNO Stark's words, a finding that the destroyers were unfit for further service "would be false." ${ }^{681}$ Jackson knew this and urged Admiral Stark to ignore the law and make a political finding of fact. ${ }^{682}$ Surely principles of professional responsibility forbid an attorney from giving an opinion based upon facts that the attorney knows to be false. 683

When Admiral Stark refused to make the preposterous finding of fact, Jackson opted for a misconstruction of Section 492. What are we to make of his misconstruction? The easy answer is simply to condemn him as an unscrupulous lawyer and leave it at that. After all, he violated his oath of office and the principles of the legal profession. A more sophisticated and realistic approach is to remind ourselves that none of us are without sin. Even the most honorable attorney may occasionally stray from the unbending path of professionalism. Jackson, the attorney, should be judged upon the basis of the entire corpus of his work and not upon a single lapse of professional judgment in the summer of 1940 . In this regard, Jackson cannot be dismissed as a simple yes man who always rubber-stamped the president's positions. In the early 1950s, he remembered that, if he told the president "that [a] statute did not permit something, I never had difficulty with him. Even if he did not agree, he would

\footnotetext{
68034 U.S.C. 491 (1940 codification).

${ }^{681}$ See notes 479 above and accompanying text.

682 See note 480 above and accompanying text.

683 In this regard, it appears that Jackson went beyond simply advising the Admiral that if the destroyers were unfit for further service, they could be sold. He actually tried to persuade the admiral to make a finding of fact that was obviously false. See note $\mathbf{4 8 0}$ above and accompanying text.
} 
accept your view." 684 In fact on occasion, Jackson rendered an opinion contrary to the president's previously expressed desires. ${ }^{685}$

To be sure, no one is perfect, but to restrict ourselves to the frailty of human nature in assessing Jackson's conduct leaves unexamined a significant aspect of the attorney-advisory process in government. If we simply dismiss his decision as willful misconduct, we may overlook significant aspects of the process. Perhaps there are occasions when violating an oath of office and the principles of the legal profession is the customary course to follow. Perhaps in some situations, Jackson's misconstruction of Section 492 is more representative of reality than the pious, public professions of attorneys.

To what extent should an attorney in public service be guided by political rather than professional judgment? On public occasions, Attorneys General are wont to make pious professions that they simply follow the law. We all know, however, that these simplistic flourishes are more a matter of public relations than professional responsibility. They are similar to the Kabuki theater of Supreme

684 Jackson Reminiscences, note 45 above, at 917-18. See also, Jackson, Draft 120, note 6 above, at 45-46: The president "had a deep respect for the personal dignity and intellectual integrity of those who served him. A difference of opinion with him could, of course, be embarrassing but only if he was convinced of disloyalty, as sometimes he was, by malicious or unintentional misinformation, did he resent reasoned disagreement."

685 For example, the Lend Lease Act had a provision that it could be terminated by a concurrent resolution of Congress, which would not require presidential approval. Roosevelt told Jackson "that he would like an opinion holding that unconstitutional," but Jackson refused because he believed that the concurrentresolution provision was constitutional. See Jackson Reminiscences, note 45 above, at 915-17; Jackson, Attorney Generalship, note 468 above, at 24-25. See also Robert H. Jackson, "A Presidential Legal Opinion," Harvard Law Review 66 (1953): 1353.

A more mundane example is the president's desire, expressed at a cabinet meeting, to prohibit the photographing of municipal airports, water supplies, and public buildings generally. Jackson had Judge Townsend explore the issue, and based upon Townsend's research, Jackson told the president "there is considerable doubt whether the statute authorizes restrictions on the properties. . . . If legislation is desired, I will be glad to prepare it." Robert Jackson to The President, 27 May 1940, Robert Jackson Papers, Box 92, Folder 1, Library of Congress, Washington, DC; Newman Townsend, Memorandum for the Attorney General, 25 May 1940, ibid.

For another example that took place before Jackson became Attorney General, see Jackson's plain-meaning interpretation of statutory language that thwarted the president's immediate desire regarding helium exports. See Bruff, Bad Advice, note 8 , above, at 62 . 
Court nomination hearings in which nominees make the ridiculous claim that justices do not make laws. Attorneys General are political animals, and the principles of professional responsibility should make allowance for this empirical fact. Everyone understands that when the law is ambiguous, attorneys have significant discretion to choose among competing interpretations. When Attorneys General weigh the validity of conflicting but plausible arguments, they likely use political rather than professional scales. Jackson certainly did so. Assuming the choice is between more-or-less tenable but conflicting analyses, there should be nothing wrong with resolving the matter in this way. Of course, there should be no pretense that the choice between the conflicting analyses is founded on professional rather than political judgment. The rub comes in situations like the Destroyer Deal when an attorney resorts to purely political considerations to reach a legally untenable solution.

Jackson seems to have viewed his tenure as Attorney General in these political terms. After he joined the Supreme Court, advocates before the Court occasionally cited his attorney general opinions, and as a justice, he made it clear that he did not feel bound by these prior opinions. He initially treated the issue with humor. ${ }^{686}$ Eventually in the Steel Seizure Case, he frankly distinguished between his role as an attorney general and his role as a judge. ${ }^{687}$

People who knew him, knew that as Attorney General, Jackson considered himself an advocate. A colleague at Justice explained,

686 In McGrath v. Kristensen, 340 U.S. 162 (1950), he described one of his published attorney general opinions as being "as foggy as the statute the Attorney General was asked to interpret." Ibid., at 176 (concurring op.). He concluded his opinion with the words of Lord Westerbury: "I can only say that I am amazed that a man of my intelligence should have been guilty of giving such an opinion." Ibid., at 178.

In Muschaney v. United States, 324 U.S. 49 (1945), the government sought to set aside a government contract as unlawful. During oral argument, Paul Freund, who argued the case for the government, related the following anecdote to the justices: "When one of the men said that this contract had been approved by the Department of Justice, another replied, 'That's impossible. Attorney General Jackson . . . is too smart a lawyer for that." Paul Freund, "Mr. Justice Jackson and Individual Rights," Mr. Justice Jackson (New York: Columbia University Press, 1969), 34, 35 . Professor Freund continued, "Well, Justice Jackson smiled faintly at the compliment and said, 'Even that doesn't persuade me."' Ibid., at 35-36. Jackson later recused himself from this case. Ibid., at 36.

687343 U.S. 579, 646-49 (1952) (concurring opinion). 
"[i]t was his job to defend, not to formulate policies." 688 Likewise, Justice Frankfurter, who knew Jackson well and apparently worked at least indirectly with Jackson on the destroyer opinion, described Attorney General Jackson as an advocate whose "function . . . is not to enlarge the intellectual horizon. His task is to seduce, to seize the mind for a predetermined end, not to explore paths to truths." ${ }^{89}$ Jackson agreed. "An Attorney General," he said in later life, "is part of a team, and ought to work with the team as far as he can. That doesn't mean he should distort the law, or anything of that sort, but he is the advocate of the administration, and necessarily partisan." 690 Continuing this chain of thought, Jackson explained, "[w]e depend on the adversary system and the Attorney General is adverse to anybody who's adverse to the administration." 691 Of course, his Section 492 analysis in the destroyer opinion was, at best, a distortion of the law. ${ }^{692}$ Moreover, his reference to the adversary system does not ring true. The hallmark of an adversary system is two advocates pitted against each other in attempts to persuade a neutral judge. In contrast, the advisory process in situations like the destroyer deal is more or less ex parte, and there is no neutral judge.

In the Steel Seizure Case, Justice Jackson was refreshingly and brutally honest about the differences between an attorney general and a judge. The case involved President Truman's authority to seize steel mills during the Korean War, ${ }^{693}$ and the government sought to use as precedent a statement by then Attorney General Jackson that President Roosevelt had authority to seize plants. ${ }^{694}$ At the Court's certiorari conference, Chief Justice Vinson noted that"Robert Jack-

688 Warner W. Gardner, "Government Attorney," Columbia Law Review 55 (1955): 438. In this same vein, Mr. Gardner explained that Jackson's Destroyers opinion "is brilliantly executed, and marshals a number of debatable propositions into an array that is powerfully persuasive." Ibid., at 444 (emphasis added).

689 Felix Frankfurter, “Mr. Justice Jackson," Harvard Law Review 68 (1955): 939.

690 Jackson Reminiscences, note 45 above, at 1102-03.

691 Jackson Reminiscences, note 45 above, at 1103 .

692 See notes 495-513 above and accompanying text.

${ }^{693}$ See generally Maeva Marcus, Truman and the Steel Seizure Case: The Limits of Presidential Power (New York: Univ. of Columbia Press, 1977).

${ }^{694}$ See ibid., at 161-62. 
son has written on it as attorney general." ${ }^{295}$ During oral argument, Jackson "wondered how much of [the government's position] was laid at my door," and the Solicitor General responded, "we lay a lot of it at your door." 696 Jackson conceded, "Perhaps rightly so," and continued, "I claimed everything, of course, like every other Attorney General does. It was a custom that did not leave the Department of Justice when I did." 697

Jackson's opinion in Steel Seizure is overtly autobiographical. ${ }^{698}$ He obviously was troubled by the Executive's use of his attorney general opinions, and he forthrightly distinguished his role as attorney general from his role as a judge. He explained that "a judge cannot accept self-serving press statements of the attorney for one of the interested parties as authority in answering a constitutional question, even if the advocate was himself." ${ }^{699}$ In discussing his opinion that President Roosevelt could seize the North American Aviation Company's plant, he first sought to distinguish the opinion on its facts. ${ }^{700} \mathrm{He}$ frankly concluded, however, that even if the opinions were indistinguishable, "I should not bind present judicial judgment by earlier partisan advocacy."

\section{CONCLUSION}

The interplay of law and politics in the process leading to Attorney General Jackson's final Destroyers-for-Bases opinion suggests topics for further exploration. A realistic model for understanding

695 The Supreme Court in Conference, 1940-1985, ed. D. Dickson (Oxford: Oxford Univ. Press, 2001), 169. In conference after oral argument, the chief justice again compared President Truman's action to "FDR at length." Robert Jackson, Conference Notes, Robert Jackson Papers, Box 176, Folder 2, Library of Congress, Washington, DC.

${ }^{696}$ Landmark Briefs and Arguments of the Supreme Court of the United States: Constitutional Law, ed. P. Kurland \& G. Casper (Washington, DC: Univ. Publ. of America, 1975), 48:920.

697 Ibid.

698 See note 459 above and accompanying text.

699 Ibid., at 647 (emphasis added). The "self-serving press statement" was his brief explanation of the President's authority to seize the North American Aviation Co. plant. See Statement of Attorney General Jackson (ca. 10 June 1941), reprinted in 89 Cong. Rec. 3992 (5 May 1943).

700343 U.S., at 648-50.

701343 U.S., at 649 n. 17. 
and evaluating the legal advisory process in government must explicitly account for the powerful influence of extralegal political considerations upon otherwise traditional legal analysis. Political influence is most obvious in a situation like Jackson's Section 492 analysis in which he simply disregarded the law. But extralegal political considerations also play a significant role in resolving a legal issue in which plausible but conflicting legal analyses are available. In these cases of ambiguity, the preference of one analysis over the other is primarily a function of political rather than legal judgment. If executive branch legal opinions are primarily or even significantly a function of political judgment, perhaps the judiciary's deference to executive branch decision-making in respect of legal issues should be reconsidered. ${ }^{702}$ Likewise, the concept of reliance upon advice of counsel ${ }^{703}$ is less attractive to the extent that advice of counsel is significantly influenced by extralegal political considerations.

At the very least, any model for judging or evaluating particular instances of legal advice rendered by government attorneys should include a moral or political component separate from the principles of professional responsibility. Moreover, the model should be firmly grounded on how attorneys actually go about doing their jobs. Professor Jack Goldsmith, in a valuable and insightful lecture, has grappled with some of the pragmatic problems confronting those who give legal advice to presidents. ${ }^{704}$ Drawing upon his own experience, Jackson's destroyer opinion, and two other opinions given to Presidents Lincoln and Kennedy, Professor Goldsmith concludes:

These lawyers exploited ambiguities and loopholes in the law. They read the relevant precedents in ways that favored presidential power. They stretched the meaning of statutes and treaties. And they did not always give full play to contrary arguments or precedents. It's quite clear that they believed, in the context in which they acted, that they were doing the right thing under the law and that they did not act in bad faith. ${ }^{705}$

702 See William R. Casto, "Executive Advisory Opinions and the Practice of Judicial Deference in Foreign Affairs Cases," George Washington International Law Review 37 (2005): 501.

${ }^{703}$ For example, there was some thought within the Bush II Administration that reliance upon the notorious torture memoranda might shield torturers from prosecution. See Jack Goldsmith, The Terror Presidency (New York: W.W. Norton, 2007), 144. See also ibid., at 170.

704 Jack Goldsmith, "Reflections on Government Lawyering," Military Law Review, 205 (2010), 192-203. Professor Goldsmith served as Assistant Attorney General, Office of Legal Counsel, in 2003-04.

705 lbid. at 199. 
Professor Goldsmith concedes that "their good faith interpretations of the law, under the pressure of events, were later viewed to be tendentious or erroneous." ${ }^{706}$ Nevertheless, he believes that Jackson and the other attorneys acted in good faith.

In the context of the advisory process, the concept of good faith may have multiple meanings or references. Good faith may mean that an attorney believes that a particular opinion or advice is supported by a proper legal analysis. At the same time, good faith may mean that the attorney believes that the opinion is based upon proper moral or political analysis. An attorney who uses traditional legal analysis to arrive at an opinion that most capable disinterested attorneys would agree is correct clearly has acted in good faith with reference to the legal analysis. Jackson's opinion on the Walsh Amendment fits this category. That opinion could also be viewed through a moral or political lens: Was his decision to facilitate the destroyer deal morally or politically proper? In rendering his opinion, Jackson was a moral and political actor responsible for the consequences of his opinion. Nevertheless, most attorneys would view an attorney who simply gives an accurate assessment regarding the existing state of law as having a significantly attenuated moral or political responsibility.

Jackson's bona fides regarding his Espionage Act raise different issues. There were at least two pertinent legal analyses of the Actone stronger; one weaker. Jackson opted for the weaker analysis that supported the president's extralegal policy objective. Most attorneys would have no problem with an attorney who opts for a weaker legal argument over a stronger one in order to facilitate the government's accomplishment of an extralegal policy objective. We would say that with reference to the legal analysis, the attorney acted in good faith. At the same time, however, the attorney's moral or political responsibility for the opinion's consequences cannot be described as attenuated. If an attorney does not use legal analysis to prefer one argument over another, the attorney bears significant moral and political responsibility.

The issue of good faith becomes quite disjointed when attention shifts to Jackson's Section 492 analysis. Professor Goldsmith believes that "it's wrong to infer bad faith from the fact of error, even clear error." ${ }^{\prime 707}$ The more reasonable inference, however, is pre-

${ }^{706} \mathrm{Jbid}$.

707 /bid. at 200. 
cisely to the contrary. Capable, sophisticated, and experienced attorneys like Robert Jackson who have worked on a problem for an extended period of time with the assistance of other gifted attorneys simply do not commit "clear legal error" in their legal analyses without knowing so. The inference should be that the attorney has not been faithful to the law.

But good faith can also be gauged in terms of whether the attorney believes that without regard to the proffered legal analysis, the advice contributes to a morally or politically appropriate result. If Professor Goldsmith means good faith in this latter since, his belief makes more sense. We may assume in this regard that Jackson informally advised the president as to the weakness of his legal analysis. ${ }^{708}$ Of course, whether an attorney may knowingly and properly render erroneous advice in order to achieve a good result is at least controversial.

In some situations like Jackson's opinion regarding Section 492, there is an obvious conflict between political judgment and the rule of law. As a matter of rule utilitarianism, the general value of the rule of law is pertinent to specific occasions of moral and political decision-making. If the particular extralegal objection sought to be attained is relatively unimportant, the rule of law will prevail. ${ }^{709}$ On other occasions, like Jackson's Section 492 opinion, the extralegal objective may be so vital that the general principal of the rule of law gives way. In the summer of 1940, the concept of the rule of law did not function as a rule. It was only a consideration.

Whether Jackson should have followed the law is not entirely clear. To be sure, under the traditional principles of legal ethics, he was bound to render an opinion based at least on an arguably correct legal analysis. Perhaps, however, these traditional principles are unrealistic in the case of an attorney general or other attorney

\footnotetext{
${ }^{708}$ Former Attorney General Elliot Richardson believed "an attorney general is not an advocate very often. In the bases-for-destroyers case, [Jackson] was not an advocate in the ordinary sense of dealing with a case in a court of law but as counsel for the chief executive who needed a legal rationale for what he was doing. He needed somebody to defend his action. Jackson was like a general counsel of a corporation who says to the CEO, 'This is not free of doubt, boss, and we may get taken to court, but I think we have a strong foundation of justification for taking this position." Baker, Conflicting Legalities, at 32, note 8 above (author's interview). Jackson agreed generally with this approach. See note 557 above and accompanying text. Of course Jackson surely did not tell the president that "we have a strong [legal] foundation of justification."

${ }^{709}$ See, e.g., note 685 above.
} 
advising the president. Suppose that Jackson's advice regarding Section 492's proviso accurately reflects actual practice in difficult cases involving high political stakes. If so, the traditional principles of legal ethics in this narrow category of cases do not comport with the actual practice of the profession. Perhaps in this narrow category, the traditional principles should be rejected as a later day example of King Canute ordering the tide not to come in.

The author of the present essay is persuaded by Dean Acheson's belief that form should not be glorified over substance when national security requires immediate action. ${ }^{710}$ Of course, human beings are adept at concluding that some cherished extralegal policy justifies lawless conduct. Moreover, the choice confronting Jackson in the summer of 1940 was not a simple binary decision to follow the law or to aid Great Britain. There were other significant factors. For example, human rights were not involved, and the president implemented the Destroyer Deal in a way subject to the powerful constraints of the political process. He did not keep it secret. ${ }^{711} \mathrm{He}$ consulted with influential members of the Republican Party and with influential members of his own party who opposed the Deal. Finally, the president almost immediately announced the Deal to the nation.

In the Destroyer Deal, Jackson opted to ignore the law in order to enable the President to assist Great Britain in a life-or-death struggle against Nazi Germany. Accordingly, he was morally and politically complicit in the President's decision. He consciously aided and abetted the transfer. As a matter of political and moral judgment, he surely was right.

\footnotetext{
710 See note 430 above and accompanying text. See also note 558 above.

711 President Roosevelt's "extensive and vigilant consultation" with the opposition has been viewed as crucial to the legitimacy of the Destroyer Deal. Arthur M. Schlesinger, Jr., The Imperial Presidency (Boston: Houghton Mifflin Co., 1973) 108. Professor Yoo writes, without elaboration, "In August, the President concluded an executive agreement with Britain, kept secret at first and without congressional approval, to make the trade." John Yoo, Crisis and Command (New York: Kaplan, 2009), 299. This description should be dismissed as an unstudied, general impression. Actually, the agreement was not formally concluded until September. More significantly, his unstudied impression that the deal was "kept secret at first and without congressional approval" elides President Roosevelt's numerous consultations with Democratic and Republican members of Congress and the Republican candidate for president before concluding the deal. Finally, the agreement together with Jackson's legal opinion was almost immediately made public. In other words, President Roosevelt adopted a procedure that subjected the deal to the powerful constraints of the political process.
} 